UNIVERSIDADE DE SÃO PAULO

INSTITUTO DE FÍSICA DE SÃO CARLOS

SUMÁRIA SOUSA E SILVA

Estudos estruturais da proteína PelD de Pseudomonas aeruginosa: um receptor de c-di-GMP responsável pela produção de exopolissacarídeos e formação de biofilmes

SÃO CARLOS - SP 



\section{Estudos estruturais da proteína PelD de Pseudomonas aeruginosa: um receptor de c-di-GMP responsável pela produção de exopolissacarídeos e formação de biofilmes}

Dissertação apresentada ao programa de PósGraduação em Física do Instituto de Física de São Carlos da Universidade de São Paulo, para obtenção do título de Mestre em Ciências.

Área de Concentração: Física Aplicada Opção: Física Biomolecular Orientador: Prof. Dr. Marcos Vicente de Albuquerque Salles Navarro.

Versão Corrigida

(versão original disponível na Unidade que aloja o Programa)

SÃO CARLOS - SP 


\section{AUTORIZO A REPRODUÇÃO E DIVULGAÇÃO TOTAL OU PARCIAL DESTE TRABALHO, POR QUALQUER MEIO CONVENCIONAL OU ELETRÔNICO PARA FINS DE ESTUDO E PESQUISA, DESDE QUE CITADA A FONTE.}

Ficha catalográfica elaborada pelo Serviço de Biblioteca e Informação do IFSC, com os dados fornecidos pelo(a) autor(a)

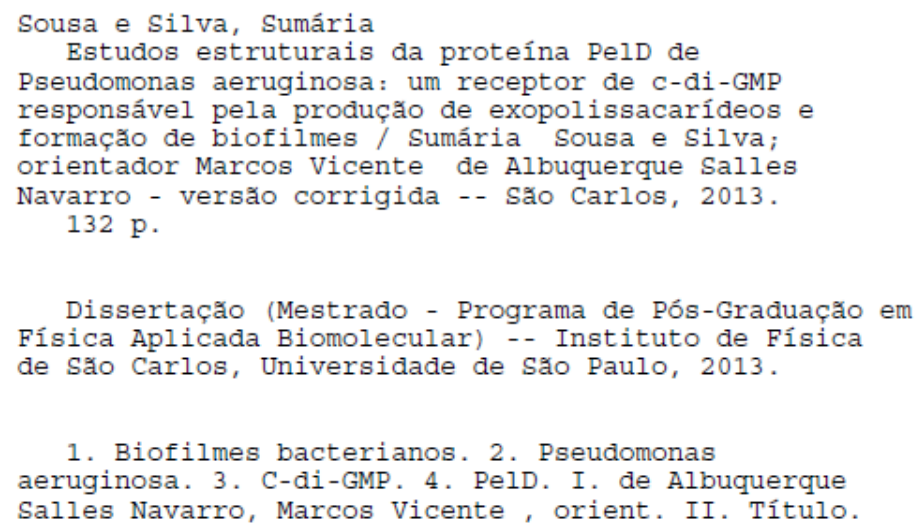




Aos meus país, José Ríbamar e Maria Suely por todo o esforço e sacrificio em prol da minha educação.

À mínha querida irmã, Suramía Sousa pela amizade e apoio incondicional em todos os momentos dessa jornada.

Ao meu companheiro, José Wilson pelo amor, incentivo, carinho e paciêncía. 



\section{AGRADECIMENTOS}

Agradeço primeiramente a Deus pela força espiritual que me manteve firme para alcançar todos os objetivos até aqui pretendidos.

Agradeço ao meu orientador $\mathcal{D} r$. Marcos Vicente de $\mathcal{A}$ lלuquerque Salles $\mathcal{N}$ avarro por sua orientação, amizade e incentivo. Como também, por sua paciêncía e persistêncía em ensinar-me, sendo de fundamental contríbuição para o desenvolvimento deste trabalho.

À minha famílía pela confíança, apoío e incentivo apesar da distâncía.

Ao meu querído companheiro José Wilson pelo amor, apoio, incentivo, paciência e também pela ajuda direta no desenvolvimento deste trabalho. Valeu $\mathcal{N}$ ego!

Aos colegas de trabalho, Éverton (Tom), Débora Orcia, Leandro (Bardi), Naty (chocolate), Edson, Bruno, Naiara, Flávio, Nathy, Helton e Juliana, pelo apoio, companheirismo, rísos e contríbuição direta ou indireta na minha formação e no desenvolvimento deste trabalho.

Ao grupo de Biofísica Molecular "Sérgio Mascarenhas", em especial às técnicas $\operatorname{Bel}$ e Andressa pelo suporte durante a rotina no Caboratório, enríquecido com ensinamentos profíssionais e pessoaís.

Ao grupo de Cristalografía do IFSC, em especial aos técnicos Humberto e Suzana pelo suporte a mim proporcionado durante este 
trabalho, principalmente no que diz respeito ao uso de alguns equipamentos, reagentes e da sala de crístalização.

Aos colegas piauienses que também entraram nessa grande jornada de pós-graduação em São Carlos e que proporcionaram muitos momentos de alegria: Washington, Adriane, Adriano, Elenice, Thairo, Orlando, Mike, Alexandre.

À dona Justina e Eliene por nos acolher em suas respectivas casas em São Carlos.

Aos colegas de curso, Julienne, Hendriane, Carol (loira), Carol (morena), Leonildo, pelo incentivo e amizade proporcionados.

Ao querido professor e grande incentivador da minha vinda a São Carlos, Dr. Francísco das Chagas Alves Lima (Chícão), o meu muito obrigado.

Às agências de fomento que prestaram apoío financeiro aos laboratórios por mim utilizados para o desenvolvimento deste trabalho, em particular a Fundação de Amparo à Pesquisa do Estado

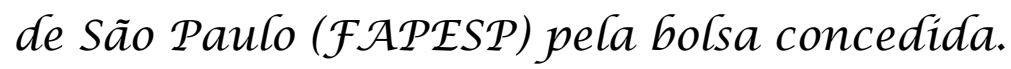

Ao IFSC-USP pelo suporte estrutural, acadêmico e financeiro.

$\mathcal{A}$ todos que de alguma forma contribuiram para a realização deste trabalho. 


\section{RESUMO}

SILVA, S. S. Estudos estruturais da proteína PelD de Pseudomonas aeruginosa: um receptor de c-di-GMP responsável pela produção de exopolissacarídeos e formação de biofilmes. 2013. 132p. Dissertação (Mestrado em Ciências) - Instituto de Física de São Carlos, Universidade de São Paulo, São Carlos, 2013.

Os microrganismos podem apresentar-se tanto em forma de vida livre como aderidos a uma superfície ou interface ar-líquido, formando comunidades complexas e dinâmicas conhecidas como biofilmes. Nos últimos anos, com o avanço das pesquisas em nível molecular, foi identificado que a maioria das bactérias utilizam guanosina monofosfato (3'-5 $)$-cíclica dimérica (c-di-GMP) como um segundo mensageiro. De forma geral, essa molécula controla a sinalização celular, virulência, comunicação entre células e a expressão de proteínas relacionadas com o fenótipo de biofilmes, em resposta à sua concentração intracelular. Sua síntese e degradação são controladas respectivamente por diguanilto ciclases (DGCs) contendo domínio GGDEF e fosfodiesterases (PDEs) que possuem os domínios EAL ou HDGYP. Em Pseudomonas aeruginosa (PA14) foi identificada uma nova classe de receptor específico para c-di-GMP, a proteína transmembranar PelD, cuja porção citoplasmática contém os domínios GAF e GGDEF degenerado. Sua modulação através desse dinucleotídeo controla a produção de exopolissacarídeos pelos componentes do conservado operon pel e influencia diretamente na capacidade de formação de biofilmes. Devido à escassez de dados a respeito dos eventos moleculares do mecanismo de sinalização mediado por c-di-GMP, este trabalho teve como objetivo principal a caracterização biofísica/estrutural da proteína PelD, bem como o reconhecimento de interação entre este ligante e a porção citoplasmática da proteína. Diversas construções solúveis de PelD foram clonadas e expressas, sendo que a construção compreendendo os resíduos 176-455 (PelD $\left.{ }^{176-455}\right)$ foi cristalizada com sucesso e teve sua estrutura determinada por iodo-SAD. O modelo final apresentou os dois domínios com enovelamentos característicos das famílias GAF e GGDEF, sendo a interface interdomínios composta majoritariamente por resíduos hidrofóbicos. Visando uma compreensão das bases moleculares de reconhecimento e ativação de PeID por c-di-GMP, uma estrutura em complexo com o ligante foi resolvida. Como esperado, o dinucleotídeo foi encontrado no sítio inibitório do domínio GGDEF, onde o motivo $\mathrm{R}^{367} \mathrm{xxD}^{370}$ e o resíduo $\mathrm{R}^{402}$ são responsáveis pela maior parte das interações com c-di-GMP. No entanto, nenhuma grande mudança 
estrutural foi observada entre as formas apo e holo de PelD, ao contrário de outros sistemas efetores tal como LapD e domínios PilZ. Curiosamente, apenas uma molécula de c-di-GMP foi encontrada no sítio, contrastando com a forma dimérica intercalada normalmente ligada aos sítios inibitórios de domínios GGDEF, tais como em PleD e WspR. Estudos de ITC confirmaram a estequiometria 1:1 em solução. Isso mostra a versatilidade dos diversos receptores já identificados até o momento, frente à ligação desse dinucleotídeo. Estudos de bioinformática identificaram uma potencial região de coiled-coil na hélice juxtamembrana de PelD, resíduos 115-160, provavelmente responsável pela homodimerização. Visando uma comprovação experimental dessa hipótese, uma construção contendo toda a porção citoplasmática, PelD ${ }^{111-455}$, foi expressa e purificada. Estudos comparativos de dicroísmo circular e ultracentrifugação analítica entre as construções PelD ${ }^{176-455}$ e PelD ${ }^{111-455}$ realmente demonstraram que os resíduos extras presentes em PelD ${ }^{111-455}$ formam uma hélice- $\alpha$ e são responsáveis pela dimerização da porção citoplasmática da proteína. De modo geral, os resultados aqui apresentados não só contribuirão para o entendimento dos mecanismos de regulação das vias de sinalização mediadas por c-di-GMP como, em longo prazo, poderão levar ao desenvolvimento de agentes contra infecções bacterianas.

Palavras-chave: Biofilmes bacterianos. Pseudomonas aeruginosa. C-di-GMP. PelD 


\begin{abstract}
$\underline{\text { ABSTRACT }}$
SILVA, S.S. Structural studies of Pseudomonas aeruginosa PelD protein: a receptor c-diGMP responsible for the production of exopolysaccharides and biofilm formation. 2013.132p. Dissertação (Mestrado em Ciências) - Instituto de Física de São Carlos, Universidade de São Paulo, São Carlos, 2013.
\end{abstract}

Microorganisms may be presented either in planktonic free-swimming life-style or adhered to surfaces, forming a complex and dynamic community known as biofilm. In recent years, with the progress of research at the molecular level, it was identified that the majority of bacteria use guanosine monophosphate (3'-5 ')-cyclic dimeric (c-di-GMP) as a second messenger. Generally, this molecule controls the cell signaling, virulence, communication between cells and expression of proteins related to the phenotype of biofilms in response to its intracellular concentration. Its synthesis and degradation are controlled respectively by diguanylate cyclases (DGC) containing the GGDEF domain and phosphodiesterases (PDE) with the domains EAL or HD-GYP. In Pseudomonas aeruginosa (PA14) a novel class of receptor specific for c-di-GMP has been identified, the transmembrane protein PelD, which contains a GAF and degenerate GGDEF domains in the cytoplasmic portion. Its modulation through this dinucleotide controls the production of exopolysaccharides by the components of the conserved operon pel and directly influences the ability of biofilm formation. Due to the paucity of data about the molecular events of the signaling mechanism mediated by c-diGMP, this study aimed to characterize biophysically and structurally the protein PelD. Various soluble constructions of PelD were cloned and expressed, and the construction comprising the residues $176-455$ (PelD ${ }^{176-455}$ ) was successfully crystallized and its structure was determined by iodine-SAD. The final model showed the two characteristic domains of families GAF and GGDEF, and the inter-domain interface composed primarily of hydrophobic residues. Seeking an understanding of the molecular basis of recognition and activation of PelD by c-di-GMP, a structure in complex with the ligand was solved. As expected, the dinucleotide was found at the inhibitory site of the GGDEF domain, where the motif $\mathrm{R}^{367} \mathrm{xxD}^{370}$ and the residue $\mathrm{R}^{402}$ are responsible for most of the interactions with c-diGMP. However, no major structural change was observed between the apo and holo forms of PelD, unlike other effector systems such as LapD and domains PilZ. Interestingly, only one molecule of c-di-GMP was present on the site, in contrast to the dimeric intercalated form 
normally found at I-sites GGDEF domains, such as PleD and in WspR. ITC studies confirmed the 1:1 stoichiometry in solution. This shows the versatility of the various receptors identified so far, compared to the binding of dinucleotide. Bioinformatics studies have identified a potential coiled-coil region in the juxtamembrane helix of PelD, residues 115-160, probably responsible for homodimerization. Aiming at an experimental confirmation of this hypothesis, a construct containing the full cytoplasmic portion, PelD ${ }^{11-455}$ was expressed and purified. Comparative studies of circular dichroism and analytical ultracentrifugation between constructs PelD ${ }^{176-455}$ and PelD ${ }^{111-455}$ indeed demonstrated that the extra residues present in PelD $^{111-455}$ form an $\alpha$-helix and are responsible for dimerization of the cytoplasmic portion of the protein. Overall, the results presented here not only contribute to the understanding of the mechanisms of regulation of signaling pathways mediated by c-di-GMP as in the long run, may lead to the development of agents against bacterial infections.

Keywords: Bacterial Biofilms. Pseudomonas aeruginosa. C-di-GMP. PELD 


\section{LISTA DE FIGURAS}

Figura 1 - $\quad$ Representação do ciclo de formação de biofilme em uma superfície. Inicialmente a bactéria encontra-se na forma livre (1), posteriormente, dependendo dos estímulos ambientais sofre uma adesão inicial (2) com crescimento e divisão seguida de adesões secundárias (3) com formação da camada protetora constituindo, portanto o biofilme maduro (4) sendo disperso por perdas de grumos limosos e agregados (5) de acordo com as condições desfavoráveis a sua sobrevivência. Cada estágio coincide com um padrão de expressão de distintos genes, sugerindo que a formação de biofilme é um processo altamente regulado.

Figura 2 - Imagens de microscopia mostrando os três tipos de polissacarídeos envolvidos na formação de biofilmes em Pseudomonas aeruginosa. (A) alginato, (B) Psl e (C) Pel.

Figura 3 - $\quad$ Esquema mostrando a síntese e a degradação de c-di-GMP. Sua síntese ocorre a partir de duas moléculas de GTP por proteínas Diguanilato Ciclases (DGCs) contendo o domínio GGDEF e sua degradação a 5'fosfoguanil-(3'-5')-guanosina (pGpG) ocorre por meio de proteínas Fosfodiesterases (PDEs) contendo os domínios EAL ou HD-GYP.

Figura 4 - $\quad$ Estrutura química e estrutura 3D do monômero e do dímero de c-diGMP. O equilíbrio em solução das duas espécies é afetado pela presença de sais monovalentes ou cátionss divalentes.

Figura 5 - $\quad$ Modelo de interação entre os complexos proteicos codificados pelo operon pel em Pseudomonas aeruginosa.

Figura 6 - $\quad$ Mapa do vetor pET-SUMO. Este vetor codifica uma proteína de fusão chamada SUMO (13657,3Da), que se apresenta fusionada a cauda de histidina (6xHis-tag) e possui um sítio de clivagem (ULP-1) específico para a proteína Sumo protease.

Figura 7 - $\quad$ Esquema ilustrando a cromatografia de afinidade por metal cobalto. (A) Interação da cauda de histidina com a proteína Sumo que por sua vez, está ligada a proteína PelD, presente na fase móvel com o metal quelado na resina da fase estacionária, permitindo recuperar de maneira seletiva a proteína de interesse. (B) Estrutura do imidazol, que compete com as histidinas pela interação com o cobalto.

Figura 7 
Figura 8 - $\quad$ Clivagem da proteína de fusão 6xHis-Sumo pela Sumo protease.

Figura 9 - Representação esquemática do experimento de cristalização por difusão de vapor em gotas suspensas. A gota contendo a proteína em solução apresenta igual composição do reservatório do poço, porém, com metade da concentração, o que leva a perda do solvente lentamente, até que as concentrações da gota e do poço adquiram uma condição de equilíbrio.

Figura 10 - Desenho esquemático dos domínios conservados presentes na proteína PelD. A predição foi realizada através dos programas Pfam e Phyre Server. Em laranja DUF4118 (18-117), em azul o GAF (180-309) e em verde o GGDEF (320-455).

Figura 11 - Predição de hélices transmembranas e topologia da proteína PelD realizada através do programa HMMTOP versão 2.0. A figura mostra que a proteína PelD possue 4 hélices transmembranas (membrana interna), que compreende o domínio DUF4118, onde a primeira está localizada entre os resíduos 19-35, a segunda entre o 44-60, a terceira entre 67-83 e a quarta entre 92-108. Sendo que, a partir do resíduo 111 inicia sua porção citoplasmática, que compreende os domínios GAF e GGDEF.

Figura 12 Predição de coiled-coil da proteína PelD, realizada através do programa MARCOIL. A figura mostra que a proteína PelD possui duas regiões com probabilidade de formar coiled-coil, ambas estão entre o domínio transmembranar DUF4118 e o domínio citoplasmático GAF.

Figura 13 - Predição de estruturas secundárias de PelD a partir da sequência primária, usando o programa PSIPRED. As hélices- $\alpha$ estão indicadas em rosa e as folhas- $\beta$ em amarelo. Acima do diagrama de estruturas secundárias encontra-se uma escala com a confiabilidade da predição e abaixo o código de letras para hélices $\alpha(\mathrm{H})$, folhas $\beta(\mathrm{E})$ e loops $(\mathrm{C})$, bem como a sequência primária de PelD.

Figura 14 - $\quad$ Eletroforese em gel de agarose $1 \%$, TAE (1x) mostrando os produtos de digestão de três clones diferentes de cada uma das 11 construções solúveis da proteína recombinante PelD. As bandas em destaque relativas ao vetor pET-SUMO aparecem em torno de $5000 \mathrm{pb}$ e os insertos, com diferentes tamanhos, estão apontados com uma seta branca.

Figura 15 - $\quad$ Análise em SDS-PAGE $15 \%$ dos testes de indução a $18^{\circ} \mathrm{C}$ em E. coli 84 BL21(DE3) para PelD ${ }^{111-455}$. (MM) Marcador de massa molecular; (1) Fração solúvel não induzida; (2-6) Frações solúveis com concentrações 
crescentes de IPTG (0,01 mM, 0,1 mM, 0,3 mM, 0,5 mM e $1 \mathrm{mM})$.

Figura 16 - Análise eletroforética da primeira etapa de purificação das construções de PelD recombinantes em resina Talon. (A) SDS-PAGE $15 \%$ para construção PelD ${ }^{111-455}$ e (B) para construção PelD ${ }^{176-455}$, onde cada canaleta representa as frações: (MM) marcador de massa molecular; (1) pellet; (2) sobrenadante; (3) lavagem; (4-9) eluição com imidazol $(10,20,50,100,250$ e $500 \mathrm{mM})$

Figura 17 - $\quad$ Análise eletroforética da clivagem e segunda IMAC das construções de PelD recombinantes. (A) SDS-PAGE $15 \%$ para construção PelD ${ }^{111-}$ ${ }^{455}$ e (B) para PelD ${ }^{176-455}$. (MM) marcador de massa molecular; (1) $1^{\mathrm{a}}$ IMAC, antes da clivagem com Ulp1; (2) Fração que não interage com a Talon (2 $2^{\mathrm{a}}$ IMAC), após clivagem. As bandas de PelD ${ }^{111-455}$ e PelD ${ }^{176-}$ 455 aparecem com a massas esperadas em torno de $39 \mathrm{kDa}$ e $30 \mathrm{kDa}$, respectivamente; (3-4) lavagem da coluna com tampão sem imidazol ( $2^{\mathrm{a}}$ IMAC); (6) eluição da SUMO-tag $(\sim 13 \mathrm{kDa})$ protease Ulp1 $(\sim 30$ $\mathrm{kDa})$ com $500 \mathrm{mM}$ Imidazol (2 $2^{\mathrm{a}}$ IMAC).

Figura 18 - $\quad$ Perfil de eluição em coluna Superdex 75 10/30 (GE) e análise eletroforética da última etapa de purificação das proteínas recombinantes. (A1) Cromatograma da PelD ${ }^{111-455}$ e (A2) da PelD ${ }^{176-}$ ${ }^{455}$; em destaque SDS-PAGE $15 \%$ mostrando frações da gel filtração, (B1) (1-3) correspondem ao pico I e (4-7) ao pico II; (B2) (1-3) correspondem ao pico I e (4-7) ao pico II.

Figura 19 - Cristais de PelD $\quad$ (A) $\quad$ obtidos após a otimização das condições iniciais. 88 (A) Cristais crescidos na condição Bis-tris $0,1 \mathrm{M}(\mathrm{pH} 6,5)$, Sulfato de amônia 0,2 M, PEG $335025 \%$ e (B) Cristais crescidos na condição Bis-tris 0,1 M (pH6,5), Sulfato de lítio monohidratado 0,2 M, PEG 3350 25\%. Em destaque um zoom dos cristais

Figura 20 - Imagem do padrão de difração de raios $X$ típico dos cristais 89 pertencentes ao grupo espacial C2 de PelD ${ }^{176-455}$.

Figura 21 - Diagrama de Ramachandran mostrando a distribuição dos ângulos $\phi$ e $\psi$ de cada resíduo, para os dois conjunto de dados (A) PelD ${ }^{176-455}$ soaking com Iodo e (B) PelD ${ }^{176-455}+\mathrm{c}$-di-GMP. As áreas rodeadas em azul claro representam as conformações que não envolvem sobreposição estérica e, portanto, são totalmente permitidas. As áreas em azul escuro indicam as conformações permitidas nos limites extremos de contatos atômicos desfavoráveis. 
Figura 22 - $\quad$ Análise topológica da estrutura tridimensional da proteína PelD ${ }^{176-455}$ correspondendo no N-terminal de uma $\mathrm{A}^{180}$ e no C-terminal uma $\mathrm{V}^{455}$. Em azul o domínio GAF, em verde o domínio GGDEF degenerado e em vermelho os resíduos envolvidos na ligação com c-di-GMP; o primeiro segmento consiste $\alpha 6-\beta 7$ : $\left(\mathrm{R}^{367} \mathrm{xxD}^{370}\right)$ e o segundo $\beta 8-\alpha 7$ : $\mathrm{T}^{391} \mathrm{e} \mathrm{R}^{402}$. Imagem gerada pelo programa Pymol.

Figura 23 - Comparação estrutural dos domínios GAF. Em azul PelD de $P .94$ aeruginosa e em vermelho a histidina kinase DosS de $M$. tuberculosis. (A) Sobreposição do domínio GAF conservado nas duas proteínas, mostrando pequenas diferenças e (B) Diagrama topológico destacando as duas pequenas hélices $\alpha$ em oposição a PelD.

Figura 24 - Comparação estrutural dos domínios GGDEF de PelD de $P .95$ aeruginosa em verde e PleD de Caulobacter crescentus em amarelo. (A) Sobreposição do domínio GGDEF conservado nas duas proteínas, mostrando as diferenças estruturais do domínio de PelD; (B) Diagrama topológico de PelD, destacando os principais elementos diferentes dos domínios GGDEF clássicos.

Figura 25 - Alinhamento múltiplo entre a PelD de $P$. aeruginosa (GGDEF degenerado) e as diversas proteínas que ligam c-di-GMP: PleD de $C$. crescentus (DGC), WspR de P. fluorescens (DGC), FimX de $P$. aeruginosa (EAL degenerado), LapD de $P$. fluorescens (EAL degenerado). Em vermelho os resíduos correspondentes ao sítio inibitório (motivo RxxD) e em verde os resíduos sítio ativo (GGD/EF).

Figura 26 - Sobreposição estrutural do domínio GGDEF de PelD de P. aeruginosa 96 (verde) e PleD de $C$. crescentus (amarelo). Em destaque encontram-se os resíduos do motivo GGDEF de PleD (laranja) e dos resíduos que compõem o sítio inibitório das proteínas (PelD em vermelho e PleD em azul). Imagem gerada pelo programa Pymol.

Figura 27 - $\quad$ Representação dos resíduos envolvidos na interação entre os domínios GAF (N-terminal) e GGDEF (C-terminal) de PelD ${ }^{176-455}$. São eles $\mathrm{Leu}^{305}, \mathrm{Leu}^{369}, \mathrm{Leu}^{340}, \mathrm{Leu}^{390}, \mathrm{Ile}^{298}$, todos apolares. Imagem gerada pelo programa Pymol.

Figura 28 - Visão estéreo da interação de c-di-GMP no sítio de ligação RxxD de 98 PelD. Os principais resíduos de interação estão destacados e o mapa diferença omite $(\mathrm{Fo}-\mathrm{Fc})$ está representado em torno da molécula de cdi-GMP com um contorno de 5 sigma. Imagem gerada pelo programa Pymol. 
Figura 29 - Sobreposição estrutural das estruturas resolvidas de PelD ${ }^{176-455}$ nas 100 formas com e sem c-di-GMP. Imagem gerada pelo programa Pymol.

Figura 30 - Sobreposição estrutural das estruturas resolvidas de PelD ${ }^{156-455}$ (4DMZ) de $P$. aeruginosa PA14 e PelD ${ }^{158-455}$ (4ETZ) de $P$. aeruginosa PA01 nas formas com e sem c-di-GMP. Imagens geradas pelo programa Pymol. Em destaque a hélice- $\alpha$ presente no N-terminal do domínio GAF, região envolvida na predição de coiled-coil.

Figura 31 - Visões ortogonais da sobreposição estrutural da construção resolvida no nosso grupo (cyan) e a estrutura 4ETZ (roxo). Na figura a direita fica claro o rearranjo relativo do domínio GGDEF em relação ao domínio GAF. Em rosa está representada a hélice S (resíduos 158176).

Figura 32 - Comparação estrutural entre as forma apo e complexadas com c-di103 GMP de estruturas de PelD contendo a hélice S. Destaque para os resíduos L390, que se afasta da hélice com ligação de c-di-GMP, e R161 que interage com a forma dimérica intercalada de c-di-GMP no sítio-I do domínio GGDEF.

Figura 33 - Superfície das estruturas de PelD ${ }^{156-455}$ e PelD ${ }^{176-455}$ mostrando a superfície de contato (laranja) entre a hélice $S$ (vermelha) e os domínios GAF (azul) e GGDEF (verde).

Figura 34 - Termograma da titulação isotérmica de c-di-GMP nas proteínas (A) 105 PelD ${ }^{111-455}$ e (B) PelD ${ }^{176-455}$. O painel superior exibe as injeções e a diluição do ligante em tampão, enquanto que o painel inferior mostra os dados de integração normalizada como uma função.

Figura 35 - Gráfico mostrando o coeficiente de partição $\left(\mathrm{K}_{\mathrm{av}}\right)$ versus o $\log$ das massas relativas dos padrões e das proteínas de interesse, a reta ajustada aos padrões e os pontos referentes às amostras de PelD nas formas apo e holo.

Figura 36 - Perfil cromatográfico das duas construções de PelD na forma apo e complexada com c-di-GMP. (A) Para PelD ${ }^{111-455}$ apo $(\mathrm{Ve}=11,00 \mathrm{~mL})$ e PelD ${ }^{111-455}$ holo $(\mathrm{Ve}=11,18 \mathrm{~mL}) ;$ para PelD $\operatorname{Pr}^{17-455}$ apo $(\mathrm{Ve}=11,53$ $\mathrm{mL})$ e PelD ${ }^{176-455}$ holo $(\mathrm{Ve}=11,54 \mathrm{~mL})$; I e II correspondem a eluição do c-di-GMP; (B) Em destaque os padrões com massas moleculares conhecidas onde B- Blue Dextran, C- conalbumina, O- ovalbumina, AC- anidrase carbônica, R-ribonuclease e A- aprotinina.

Figura 37 - Dados parciais de velocidade de sedimentação mostrando o ajuste 109 utilizando o software SEDFIT. (A) Curvas de absorbância em $280 \mathrm{~nm}$ 
versus o raio da cela, para PelD ${ }_{111-455}$ em tampão Tris-HCl $25 \mathrm{mM}(\mathrm{pH}$ 8,0), $\mathrm{NaCl} 500 \mathrm{mM}$. (B) Resíduos fornecidos pelo mesmo software mostrando a qualidade do ajuste.

Figura 38 - $\quad$ Experimento de velocidade de sedimentação para as duas construções da PelD em tampão Tris-HCl 25 mM (pH 8,0), NaCl 500 mM. (A) para PelD ${ }^{111-455}$ e (B) para PelD ${ }^{176-455}$ no intervalo de concentração correspondente a uma absorbância de 0,2 a 1 .

Figura 39 - Espectro de Dicroísmo Circular na região de UV-distante para (A) PelD ${ }^{111-455}$ e (B) PelD ${ }^{176-455}$ na forma apo e holo (complexada com cdi-GMP).

Figura 40 - $\quad$ Mecanismo proposto para ativação de PelD por c-di-GMP. A figura mostra que a partir do momento que a célula sofre estímulos externos, a concentração intracelular de c-di-GMP aumenta o que possibilita a interação com a porção citoplasmática da proteína PelD. Essa interação promove uma alteração conformacional em PelD, o que possibilita sua provável interação com a proteína PelF, uma glicosiltransferase que sintetiza o polímero pel. Sua exportação é facilitada pela interação desta com PelD fazendo com que o polímero Pel seja exportado para a região periplasmática de $P$. aeruginosa (PA14). 


\section{LISTA DE TABELAS}

Tabela 1 - Infecções humanas causadas pela formação de biofilmes.

Tabela 2 - $\quad$ Receptores específicos para c-di-GMP.

Tabela 3 - Oligonucleotídeos desenhados para clonagem das diferentes 60 construções de PelD de Pseudomonas aeruginosa (PA14). As bases em vermelho correspondem aos sítios de reconhecimento das enzimas de restrição selecionadas.

Tabela 4 - $\quad$ Programa de PCR executado para amplificação das construções de PelD de Pseudomonas aeruginosa (PA14).

Tabela 5 - $\quad$ Estatísticas da coleta e processamento dos dados de difração de raios X e refinamento das estruturas de $\mathrm{PelD}^{176-455}$ na forma apo e complexada com c-di-GMP.

Tabela 6 - $\quad$ Análise dos parâmetros de validação dos dois conjuntos de dados da PelD gerados pelo programa MolProbity.

Tabela 7 - Parâmetros termodinâmicos dos complexos formados pelas duas construções de PelD à uma temperatura de $25^{\circ} \mathrm{C}$.

Tabela 8 -

Porcentagem de estruturas secundárias das proteínas recombinantes PelD ${ }^{111-455}$ (apo e holo) e PelD ${ }^{176-455}$ (apo e holo). Obtidas pelo programa CDpro. 



\section{LISTA DE ABREVIATURAS E SIGLAS}

\begin{tabular}{|c|c|}
\hline AUC & Analytical UltraCentrifugation \\
\hline c-di-GMP & Bis-(3'-5')-cyclic dimeric guanosine monophosphate \\
\hline $\mathrm{CD}$ & Circular Dichroism \\
\hline dNTPs & Desoxinucleotídeos \\
\hline DO & Densidade óptica \\
\hline ExPASy & Expert Protein Annalysis $\underline{\text { System }}$ \\
\hline EPS & Exopolissacarídeo \\
\hline НMМТОР & 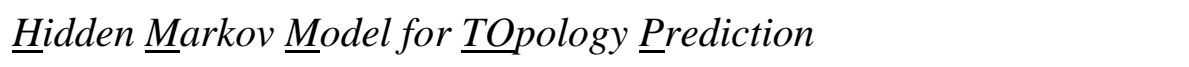 \\
\hline IPTG & Isopropil- $\beta$-D-galactopiranosídeo \\
\hline ITC & Isothermal Titration $\underline{\text { Calorimetry }}$ \\
\hline LB & Meio de cultura Lúria $\underline{B}$ roth \\
\hline NMWL & 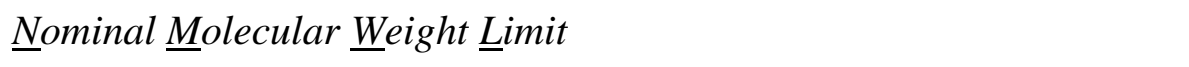 \\
\hline PCR & Polymerase $\underline{\text { Chain }}$ Reaction \\
\hline PDB & Protein $\underline{\text { Data }} \underline{\text { Bank}}$ \\
\hline PEG & Polietilenoglicol \\
\hline PHENIX & 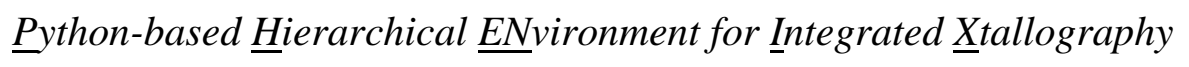 \\
\hline PHYRE & Protein $\underline{H}$ omology/analog $\underline{\text { YRecognition } \underline{E} \text { ngine }}$ \\
\hline $\mathrm{pH}$ & Potencial hidrogeniônico \\
\hline pI & Ponto isoelétrico \\
\hline psl & Polysaccharide synthesis locus \\
\hline rpm & Rotação por minuto \\
\hline SDS-PAGE & Eletroforese em gel de poliacrilamida com sulfato de dodecil de sódio \\
\hline SAD & Single Wavelength $\underline{\text { Anomalous }}$ Dispersion \\
\hline SUMO & 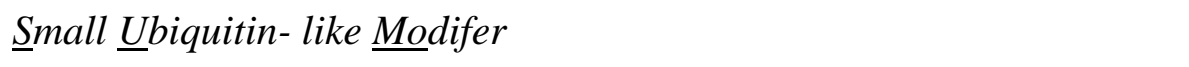 \\
\hline ULP & Ubiquitin- like proteins \\
\hline UV & Ultravioleta \\
\hline $\mathrm{VC}$ & Volume de coluna \\
\hline
\end{tabular}





\section{LISTA DE SÍMBOLOS}

$\begin{array}{ll}\AA & \text { Angstrom }\left(10^{-10} \mathrm{~m}\right) \\ { }^{\circ} \mathrm{C} & \text { Graus Celsius } \\ \mathrm{Da} & \text { Daltons } \\ \mathrm{kb} & \text { Quilobases } \\ \mathrm{kDa} & \text { Quilodaltons }\left(10^{3} \mathrm{~g} / \mathrm{mol}\right) \\ \mathrm{L} & \text { Litros } \\ \mathrm{M} & \text { Molar } \\ \mathrm{mg} & \text { Miligrama } \\ \mathrm{mL} & \text { Mililitro } \\ \mathrm{mM} & \text { Milimolar } \\ \mathrm{nm} & \text { Nanômetro } \\ \mathrm{ng} & \text { Nanograma } \\ \mathrm{pb} & \text { Pares de base } \\ \mathrm{U} & \text { Unidade (s) de enzima } \\ \mu \mathrm{L} & \text { Microlitro } \\ \mu \mathrm{M} & \text { Micromolar } \\ \lambda & \text { Comprimento de onda }\end{array}$



NOME

Alanina

Leucina

Valina

Isoleucina

Prolina

Fenilalanina

Glicina

Cisteína

Triptofano

Metionina

Serina

Treonina

Glutamina

Tirosina

Asparagina

Ácido aspártico

Ácido glutâmico

Arginina

Lisina

Histidina
SÍMBOLO

Ala

Leu

Val

Ile

Pro

Phe

Gly

Cys

Trp

Met

Ser

Thr

Gln

Tyr

Asn

Asp

Glu

Arg

Lys

His

\section{ABREVIAÇÃO}

A

$\mathrm{L}$

V

I

$\mathrm{P}$

F

G

C

W

M

S

$\mathrm{T}$

Q

Y

$\mathrm{N}$

D

E

$\mathrm{R}$

K

$\mathrm{H}$

\section{CARACTERÍSTICA}

Apolar

Apolar

Apolar

Apolar

Apolar

Apolar

Polar

Apolar

Apolar

Apolar

Polar não carregado

Polar não carregado

Polar não carregado

Polar não carregado

Polar não carregado

Negativo

Negativo

Positivo

Positivo

Positivo 



\section{SUMÁRIO}

CAPÍTULO 1

1 INTRODUÇÃO ........................................................................................................31

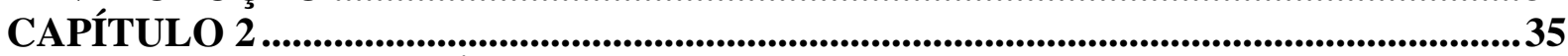

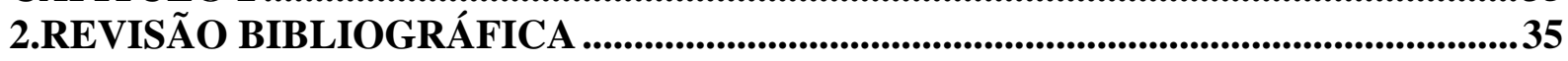

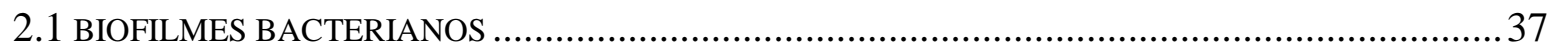

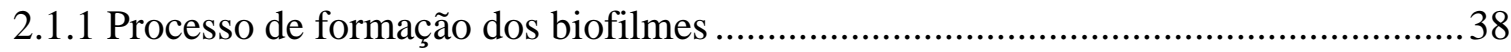

2.1.2 Impactos promovidos pelos biofilmes bacterianos .................................................. 40

2.1.3 Sistema de quorum sensing como adjuvante na formação de biofilmes....................4 41

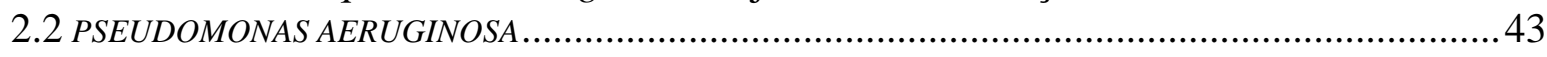

2.3 C-DI-GMP: MOLÉCULA SINALIZADORA EM BACTÉRIAS ..................................................... 46

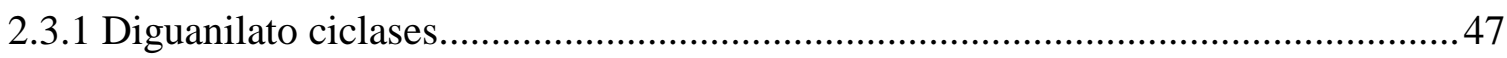

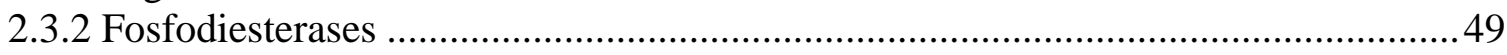

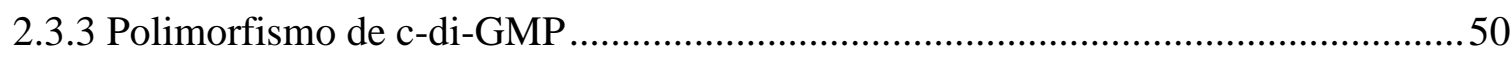

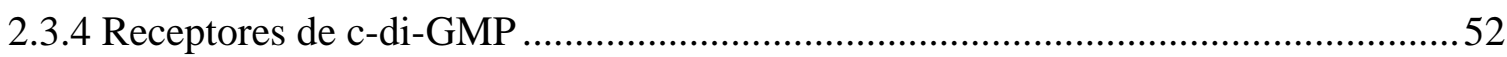

2.4 PROTEÍNA PELD DE PSEUDOMONAS AERUGINOSA (PA14) ...................................................53

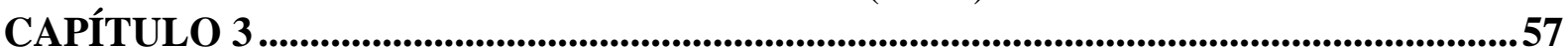

3. MATERIAIS E MÉTODOS.............................................................................................57

3.1 MATERIAIS E MÉTODOS................................................................................59

3.1.1 Análise da proteína PelD de Pseudomonas aeruginosa (PA14) por meio de

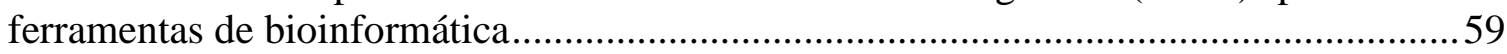

3.1.2 Amplificação dos genes e delimitação das construções ...............................................6

3.1.3 Clonagem dos genes de PelD em vetor de expressão pET-SUMO (Invitrogen) ......61

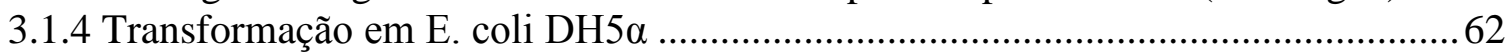

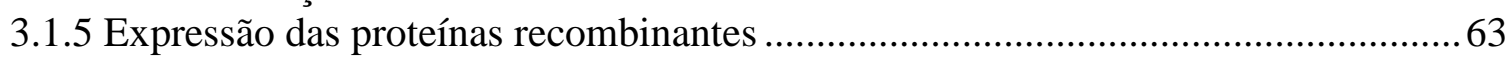

3.1.6 Purificação por cromatografia de afinidade por metal imobilizado (IMAC)............64

3.1.7 Clivagem da proteína de fusão (6xHis-Sumo) utilizando a protease ubiquitin-like

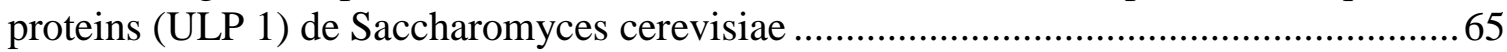

3.1.8 Purificação por cromatografia de exclusão por tamanho ............................................67

3.1.9 Produção enzimática do ligante c-di-GMP a partir da proteína YdeH, uma

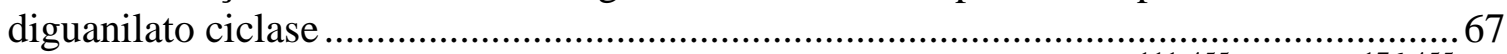
3.1.10 Caracterização biofísica das proteínas recombinantes PelD ${ }^{111-455}$ e PelD $^{176-455}$ de

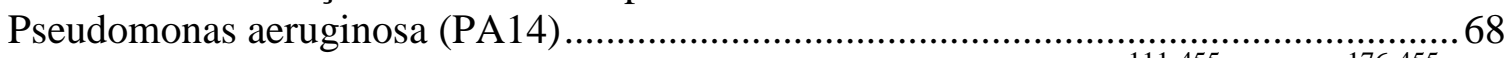
3.1.11 Estimativa da massa molecular aparente das proteínas PelD ${ }^{11-455}$ e PelD ${ }^{176-455}$ nas formas apo e holo por cromatografia de exclusão por tamanho .........................................6 68

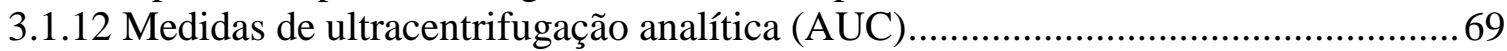

3.1.13 Medidas de calorimetria de titulação isotérmica (ITC)............................................71

3.1.14 Medidas de dicroísmo circular (CD) ...............................................................72

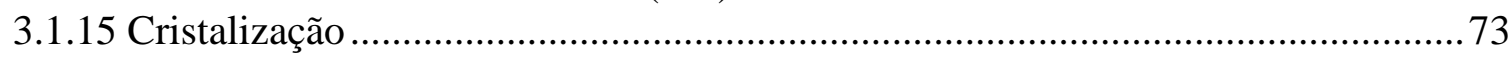

3.1.16 Resolução estrutural por difração de raios-X ......................................................... 75

CAPÍTULO 4 ..................................................................................................................................77

4. RESULTADOS E DISCUSSÃO _........................................................................

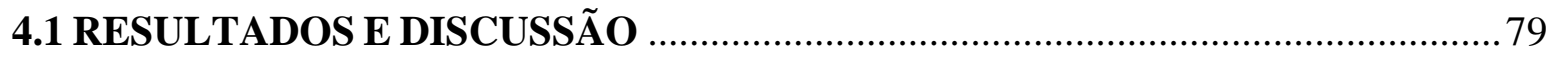

4.1.1 Análise da sequência de aminoácidos e delimitação da construção solúvel de PelD utilizando as ferramentas de bioinformática ....................................................................79 4.1.2 Amplificação e clonagem das construções de PelD em vetor de expressão pET-

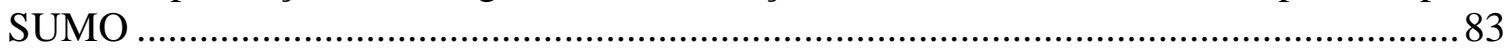

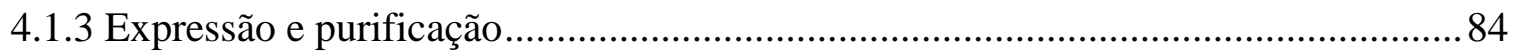


4.1.4 Cristalização, coleta e processamento dos dados de difração de PelD ${ }^{176-455}$............ 88

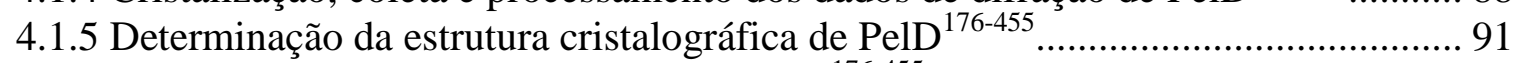

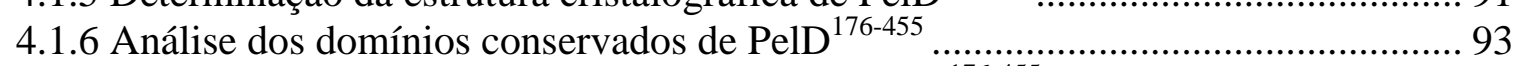

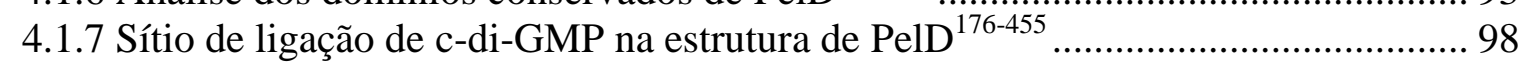

4.1.8 Comparação das estruturas de PelD com e sem c-di-GMP .................................. 100

4.1.9 Potencial papel de c-di-GMP na ativação de PelD ............................................... 100

4.1.10 Afinidade, estequiometria e termodinâmica de ligação de c-di-GMP em PelD .. 104

4.1.11 Estudos de oligomerização da porção solúvel de PelD em solução ..................... 106

4.1.12 Análise de dicroísmo circular das duas construções de PelD na forma apo e

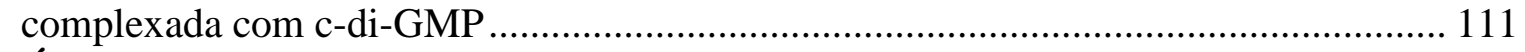

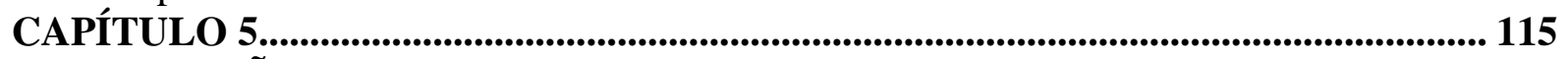

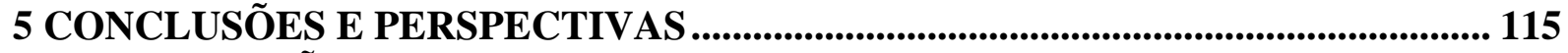

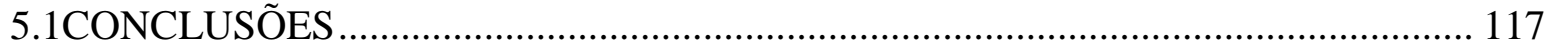

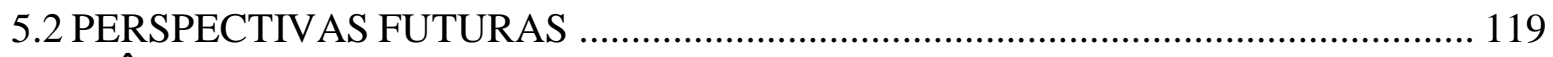

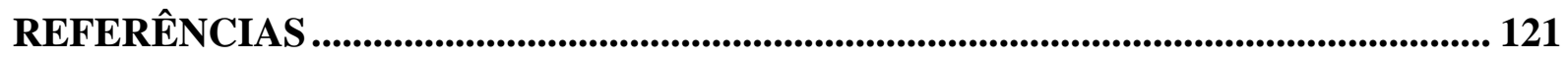


Papitulo 1

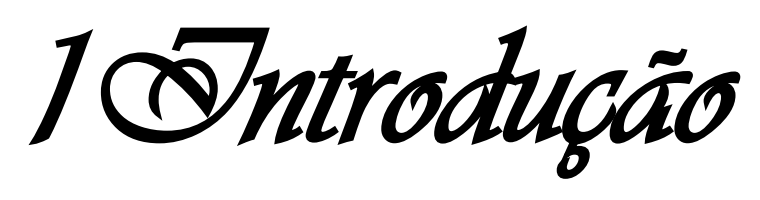

Neste capítulo pretende-se contextualizar o leitor para o tema deste trabalho. Apresentam-se, também, os objetivos dessa pesquisa, bem como, o modo como esta foi organizada. 


\section{INTRODUÇÃO}

Na maior parte da história da microbiologia, os microrganismos foram caracterizados como células livremente suspensas e descritos com base nas características de crescimento em meios de cultura nutricionalmente ricos. (1) A descoberta de um fenômeno microbiológico, descrita pela primeira vez por van Leeuwenhoek, que os microrganismos juntam-se e crescem universalmente em superfícies expostas, conduziram a estudos que revelaram microrganismos associados em superfícies (biofilmes) e que exibiam um fenótipo distinto no que diz respeito à taxa de transcrição de genes e do seu crescimento. (2) Estes biofilmes microbianos têm demonstrado induzir mecanismos específicos para fixação a uma superfície inicial de desenvolvimento, estrutura da comunidade e dos ecossistemas envolvidos. Além disso, os biofilmes apresentam grande importância para a saúde pública devido ao seu papel em certas doenças infecciosas e importância em uma variedade de infecções relacionadas a dispositivos médicos. (3) Uma melhor compreensão desses processos deve proporcionar novas e eficazes estratégias de controle ou até mesmo a inibição de formação do biofilme.

Sendo assim, o biofilme consiste de colônias de bactérias inseridas em uma matriz polimérica extracelular por elas mesma produzida. (4) Essa estrutura estabelecida do biofilme compreende células microbianas e exopolissacarídeos (EPS), que apresenta uma arquitetura definida, e fornece um ambiente ideal para a troca de material genético entre as células. A mesma constitui ainda como forma de proteção que permite ao microrganismo sobreviver em ambientes adversos. Além disso, as células também podem comunicar através do sistema de quorum sensing, que por sua vez pode afetar processos do biofilme, como o desprendimento. (4-5)

Estima-se que mais de $90 \%$ dos microrganismos vivem sob a forma de biofilmes e praticamente não existe nenhuma superfície que não possa ser ou vir a ser colonizada por bactérias. (5-6) Quanto a sua composição, a mesma é dependente das condições do meio como: temperatura, composição do meio, pressão, pH e oxigênio (3-6) e não é necessariamente uniforme, podendo até englobar partículas sólidas (argilas, areias, partículas orgânicas) provenientes do meio onde está imerso. (7-8)

Dos microrganismos frequentemente encontrados no biofilme, as bactérias apresentam-se como o grupo predominante. As elevadas taxas de reprodução, grande 
capacidade de adaptação e de produção de substâncias e estruturas extracelulares, são as principais características que fazem das bactérias organismos com grandes capacidades de produção de biofilme. (9-10) Pseudomonas, Bacillus, Flavobactrium, Staphylococus, são os gêneros mais comuns de bactérias produtoras de biofilme ainda que umas apresentem, naturalmente, uma maior aptidão que outras. A família de bactérias mais pesquisada em termos de adesão em superfícies pertence à Pseudomonadaceae, sendo o gênero Pseudomonas o mais estudado. (3)

A bactéria patogênica Pseudomonas aeruginosa por sua vez, produz uma matriz extracelular, os exopolissacarídeos (EPS) que têm despertado grande interesse em aplicações industriais e na área médica, (11) como também têm sido considerados como um problema, interferindo nos mecanismos imunológicos contra infecções bacterianas. (12-13,14) Apesar dos EPS serem os componentes da matriz extracelular mais estudado, existe uma grande variedade de EPS que ainda permanece não caracterizado. Por exemplo, o exopolissacarídeo pel produzido durante a formação de biofilmes de Pseudomonas aeruginosa. O mesmo é produzido por um conjunto de proteínas codificadas pelos genes do conservado operon pel, e esse polissacarídeo ainda não apresenta estrutura e nem composição conhecida. (15-18)

Nos últimos anos, com o avanço das pesquisas em nível molecular, foi identificado que a maioria das bactérias inclusive Pseudomonas aeruginosa, utilizam guanosina monofosfato (3'-5')-cíclica dimérica (c-di-GMP) como um segundo mensageiro.(19-23) De forma geral, essa molécula controla a sinalização celular, virulência, comunicação entre células e a expressão de proteínas relacionadas com o fenótipo de biofilmes, em resposta à sua concentração intracelular. Sua síntese e degradação são controladas respectivamente por diguanilto ciclases (DGCs) contendo domínio GGDEF e fosfodiesterases (PDEs) que possuem os domínios EAL ou HD-GYP. (24-25) Em Pseudomonas aeruginosa (PA14) foi identificada uma nova classe de receptor específico para c-di-GMP, a proteína transmembranar PelD, cuja porção citoplasmática contém os domínios GAF e GGDEF degenerado. (26-28) Sua modulação através desse dinucleotídeo controla a produção de exopolissacarídeos pelos componentes do conservado operon pel e influencia diretamente na capacidade de formação de biofilmes. (29-30)

Devido à escassez de dados a respeito dos eventos moleculares do mecanismo de sinalização mediado por c-di-GMP, este trabalho teve como objetivo principal realizar a 
caracterização estrutural da proteína PelD de Pseudomonas aeruginosa (PA14) para compreender seu mecanismo de ativação por c-di-GMP. Para tanto foi necessário determinar protocolos de expressão e purificação para as construções solúveis da porção citoplasmática da proteína transmembranar PelD de Pseudomonas aeruginosa (PA14); cristalizar e resolver a estrutura da mesma com e sem o ligante c-di-GMP; e por fim realizar estudos em solução com PelD para investigar suas formas oligoméricas e afinidade por c-di GMP.

Esta dissertação está dividida em cinco capítulos organizados de forma a apresentar o trabalho desenvolvido ao longo desta pesquisa. Neste primeiro capítulo, pretende-se orientar o leitor para o tema deste trabalho, apresentando-se o contexto e as motivações que estiveram na base desta dissertação. Também se expõe os objetivos geral e específico da dissertação, bem como o modo como esta foi organizada. O segundo capítulo constitui uma breve revisão bibliográfica sobre o tema dos biofilmes bacterianos e suas bases moleculares. Apresenta-se, portanto, o conceito de biofilme, apontando as suas principais vantagens e desvantagens, principalmente na área médica. Por fim, faz-se uma explanação sobre a proteína em estudo, e também de que forma ela está envolvida no contexto do biofilme propriamente dito, assim como as bases moleculares envolvidas. No terceiro capítulo, apresentam-se os materiais e métodos usados durante a execução do trabalho experimental. Os resultados obtidos são apresentados, relacionados e discutidos no quarto capítulo. Neste capítulo discute-se toda a caracterização estrutural da proteína PelD, bem como estado oligomérico e interação com o ligante c-di-GMP, baseado nas técnicas biofísicas utilizadas. No quinto capítulo faz-se uma síntese das principais conclusões resultantes do trabalho experimental realizado no domínio desta dissertação e apresentam-se, no seguimento, algumas ideias e sugestões para trabalhos futuros. 
Papitulo 2

2 Revisão bibliográfica

Neste capítulo serão apresentados os principais tópicos sobre a formação dos biofilmes bacterianos, desde a sua descoberta até as vias de biossíntese responsáveis pela sua formação. Neste contexto abordaremos principalmente biofilmes formados por Pseudomonas aeruginosa, uma bactéria altamente patogênica e que apresenta genes envolvidos na formação da camada de exopolissacarídeos. Dentre eles o operon pel, que apresenta o gene codificante para a proteína PelD, foco deste trabalho. 


\subsection{Biofilmes bacterianos}

A Microbiologia é classicamente definida como a área da ciência que se dedica ao estudo de organismos que somente podem ser visualizados ao microscópio. Com base neste conceito, a microbiologia aborda um vasto e diverso grupo de organismos unicelulares de dimensões reduzidas, que podem ser encontrados como células isoladas ou agrupados em diferentes arranjos. Assim, a microbiologia envolve o estudo de organismos procarióticos (bactérias, archaeas), eucarióticos (algas, protozoários, fungos) e também seres acelulares (vírus). (1)

Esta área do conhecimento teve seu início com os relatos de Robert Hooke (16351703) e Antony van Leeuwenhoek (1632-1723), que desenvolveram microscópios que possibilitaram as primeiras observações de bactérias e outros microrganismos a partir da análise de diversos espécimes biológicos. Embora van Leeuwenhoek seja considerado o "pai" da microbiologia, os relatos de Hooke, descrevendo a estrutura de um bolor, foram publicados anteriormente aos de Leeuwenhoek. (2) Assim, por mais que Leeuwenhoek tenha fornecido importantes informações sobre a morfologia bacteriana, os dois pesquisadores devem ser considerados como pioneiros nesta ciência. (3-4) Nas últimas décadas, houve uma "revolução" na microbiologia, a qual passou e ainda vem passando por profundas modificações, especialmente no que se refere aos conhecimentos sobre ecologia e classificação dos microrganismos. (1-2)

Anteriormente, os microrganismos (principalmente os procariotos) eram considerados seres unicelulares de comportamento independente, mesmo que fossem encontrados em agrupamentos contendo diversas células. (1) Assim, a maior parte dos conhecimentos foi obtida a partir de culturas puras. Isto é, o microrganismo era isolado da natureza e, após ser "separado" dos demais microrganismos, era cultivado em laboratório, gerando populações contendo um único tipo celular.

No entanto, estudos efetuados a partir da década de setenta demonstraram que no homem e na natureza os microrganismos existem muitas vezes integrados a comunidades mistas e aderentes a superfícies ou interfaces ar-líquido, por exemplo, e que são envolvidas por uma matriz exopolissacarídica (EPS). $(3,7)$ 
Hoje se sabe que grande parte dos microrganismos vive em comunidades na natureza, compostas muitas vezes por inúmeros gêneros e espécies distintos, que cooperam entre si, como em uma cidade microbiana. (1,4) Estas comunidades complexas e dinâmicas que possuem normalmente maior resistência aos antibióticos e desinfetantes designam-se de biofilmes, e podem incluir bactérias, fungos filamentosos, leveduras e protozoários. Estima-se que cerca de $90 \%$ das bactérias da natureza em algum momento se apresentam sob a forma de biofilme, exercendo importantes atividades em nosso planeta. (3)

\subsubsection{Processo de formação dos biofilmes}

Muitas teorias têm sido propostas com relação à dinâmica de formação de um biofilme, mas algumas etapas fundamentais são concordantes em todas elas, as principais são: contato, adesão, formação de microcolônias, maturação e desprendimento (figura 1), as mesmas são dependentes da influência do meio ambiente e das características genéticas das bactérias. (9-12)

Inicialmente temos organismos denominados colonizadores primários, as bactérias circulantes, ao entrarem em contato com uma superfície, iniciam o processo de adesão formando pontes de ligação entre si e a superfície, geralmente contendo proteínas ou outros compostos orgânicos. As células aderidas passam a se desenvolver, originando microcolônias que sintetizam uma matriz exopolissacarídica (EPS), que passa a atuar como substrato para a aderência de microrganismos denominados colonizadores secundários. (13) Estes colonizadores secundários podem se aderir diretamente aos primários, ou promover a formação de coagregados com outros microrganismos. (14-16) Uma vez formado, o biofilme pode permanecer aderido à superfície por um longo período ou então se desprender, servindo como uma fonte perpetuadora do ciclo ao liberar formas planctônicas para colonização de novos sítios à distância. Compreendendo, portanto em um processo de transição de uma forma livre planctônica, onde os micróbios comportam-se independentemente, para uma forma de vida séssil, em comunidade multicelular. (17-18) 


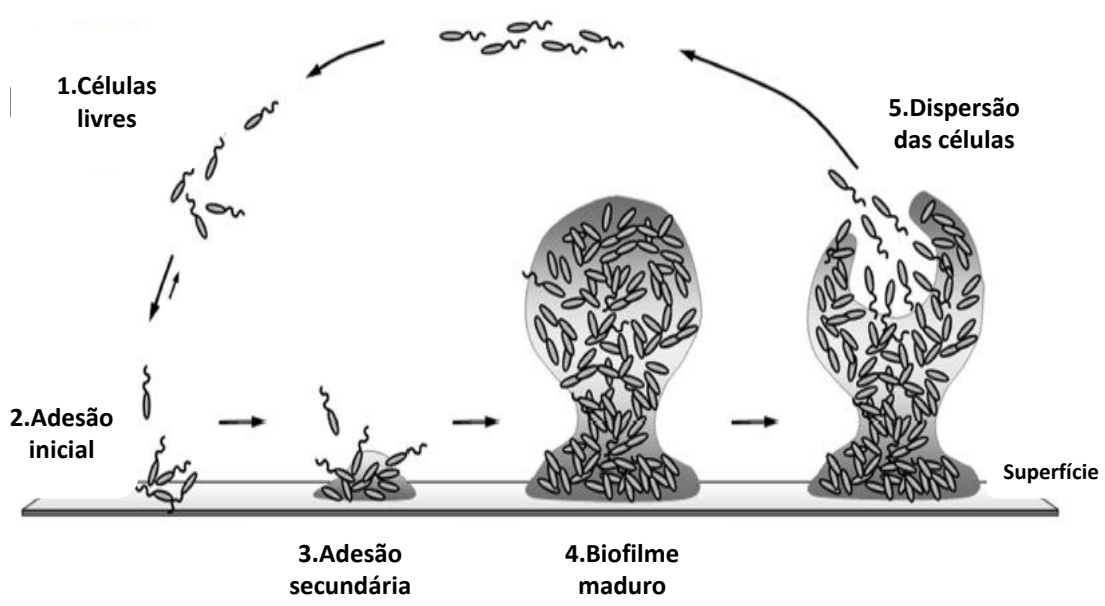

Figura 1 - Representação do ciclo de formação de biofilme em uma superfície. Inicialmente a bactéria encontrase na forma livre (1), posteriormente, dependendo dos estímulos ambientais sofre uma adesão inicial (2) com crescimento e divisão seguida de adesões secundárias (3) com formação da camada protetora constituindo, portanto o biofilme maduro (4) sendo disperso por perdas de grumos limosos e agregados (5) de acordo com as condições desfavoráveis a sua sobrevivência. Cada estágio coincide com um padrão de expressão de distintos genes, sugerindo que a formação de biofilme é um processo altamente regulado. Adaptado (6)

À medida que a população em sua proximidade aumenta, as bactérias formam microcolônias dispostas em pilares, composto por uma camada com cerca de $10 \mu \mathrm{m}$ de espessura, podendo se estender em até $200 \mu \mathrm{m}$ acima. (1) Essa forma de crescimento em pilares tem haver principalmente a sua sobrevivência no meio, pois se as bactérias crescessem em uma camada uniforme e espessa ficariam abarrotadas de microrganismos, e não haveria nutrientes disponíveis a grandes profundidades e resíduos tóxicos poderiam se acumular. Quando agrupadas em pilares de biofilmes evitam esse problema, devido à existência de canais entre elas por onde a água transporta os nutrientes que chegam e os resíduos que saem, constituindo um sistema circulatório simples. $(10,15,17)$

Embora a formação fisiológica de biofilme já tenha sido reconhecida e documentada cientificamente a mais de 40 anos, acredita-se que estamos apenas começando a entender esse processo a nível molecular. (18) Análises genéticas desses estudos têm fornecido informações importantes para o entendimento da formação de biofilme. No entanto, essas análises são dificultadas principalmente por sua composição, composta de múltiplas espécies microbianas, que são embebidas em uma matriz polimérica protetora, o que dificulta ainda mais o entendimento em nível molecular, já que, existe uma facilidade de transferência horizontal de genes. (3-5) 
Apesar disso, há uma predominância na maioria dos ambientes de biofilmes de espécie única, e estas espécies é o foco da maioria das pesquisas atuais. Destaque para Pseudomonas aeruginosa, um patógeno oportunista, que emergiu como uma das bactérias gram negativas mais estudadas, por formar biofilmes de espécie única e apresentar um grande potencial de virulência. (18) Outras bactérias gram-negativas também podem formar biofilmes de espécie única, tais como: Pseudomonas fluorescens, Escherichia coli e Vibrio cholerae. Dentre as bactérias gram-positivas formadoras de biofilme que têm sido estudadas incluem: Staphylococcus epidermidis, Staphylococcus aureus. (15-16)

\subsubsection{Impactos promovidos pelos biofilmes bacterianos}

Em meios industriais a formação de biofilmes pode levar, por exemplo, à corrosão e obstrução de tubagens, bem como à contaminação de produtos alimentares e ainda a entupimento de canos. (13) Na medicina humana, biofilmes podem se formar em dispositivos médicos implantados no homem, como catéteres vasculares. (31)

Por outro lado, a formação de biofilmes, em alguns casos, pode ser benéfica. Aplicações baseadas em biofilmes têm sido desenvolvidas para a biorremediação de hidrocarbonetos e metais pesados, (32) na descontaminação e degradação de vazamentos químicos em grande escala e na produção de produtos naturais usados na produção de aditivos alimentares, produtos de limpeza e medicamentos. Por exemplo, existem comunidades bacterianas aderidas aos biorreatores que proporcionam a produção de fermentados. Além disso, existem bactérias que produzem ácido acético que se agregam em fragmentos de madeira e convertem diversos substratos em vinagre. Agregados microbianos também são usados em tratamentos aeróbicos e anaeróbicos de efluentes domésticos e industriais. No processo de tratamento de água potável, na remoção do nitrogênio, carbono biodegradável e precursores de trihalometanos, obtidas por biofilmes microbianos submersos. (31-32)

Nos últimos anos, constatou-se que os biofilmes têm também um papel preponderante na patogênese de numerosas infecções (tabela 1) que não envolvem biomateriais. De fato, cerca de 60-80\% das infecções humanas de etiologia bacteriana 
poderão envolver biofilmes. (33) Estas infecções podem afetar a cavidade oral (dentes e gengivas), o trato urogenital e o trato respiratório.

Tabela 1 - Infecções humanas causadas pela formação de biofilmes. Adaptado. (14)

\begin{tabular}{cc}
\hline INFECÇÕES & ESPÉCIES BACTERIANAS ENVOLVIDAS \\
\hline Cárie dentária & Streptococcus mutans, Lactobacillus spp. \\
Periodontite & $\begin{array}{c}\text { Porphyromonas gingivalis, } \text { Prevotella } \\
\text { intermedia, Fusobacterium nucleatum }\end{array}$ \\
Otite média & Estirpes atípicas de Haemophilus \\
influenzae \\
Infecções do trato biliar & Bactérias entéricas (ex. E. coli) \\
Pneumonia da fibrose cística & P. aeruginosa e Burkholderia cepacia \\
Cistite dos cateteres urinários & E. coli e outros bacilos Gram (-) \\
Endocardite bacterianasubaguda & Estreptococos do grupo viridans \\
\hline
\end{tabular}

Normalmente essas infecções microbianas caracterizam-se pela sua cronicidade e pela elevada resistência ao tratamento com antibióticos, o que torna o diagnóstico difícil. Por exemplo, os biofilmes que se formam no corpo humano, em comparação com aqueles formados sobre superfícies e sistemas inertes, adquirem geralmente uma estrutura mais complexa. (31) Devido à ação de algumas proteínas do hospedeiro como a fibronectina (uma proteína adesiva), que se liga aos glóbulos vermelhos e a outros materiais que, em conjunto com os exopolissacarídeos bacterianos, também participam da formação do biofilme. (33-34)

\subsubsection{Sistema de quorum sensing como adjuvante na formação de biofilmes}

Depois de muitos anos de estudos, as respostas para algumas das perguntas referentes à regulação gênica dependente de densidade populacional das bactérias começaram a surgir. Mostrou-se que a comunicação intercelular bacteriana é realizada através da produção e liberação no meio externo de pequenas moléculas, chamadas de auto-indutores e, em 1994, esse fenômeno recebeu o nome de sentir o quorum (do inglês, quorum sensing). Esse termo foi adotado pelo fato da ativação de um determinado fenômeno ser depende de uma densidade populacional (quorum) elevada. (35) 
O quorum sensing corresponde a um processo de comunicação intra e interespécies microbianas, que permite aos microrganismos apresentarem alterações fenotípicas marcantes quando estes se encontram em altas densidades populacionais. (36) A descoberta deste tipo de interação microbiana tornou evidente o conceito que, embora geneticamente e estruturalmente mais simples, os microrganismos têm a capacidade de se comportar como organismos complexos, capazes de se comunicar e agir coordenadamente, respondendo a diferentes estímulos de modo unificado. (37-38)

Sistemas de quorum sensing parecem regular a expressão de grupos principais de moléculas microbianas: moléculas de superfície e moléculas extracelulares. Graças a esse sistema de regulação gênica, nos estágios iniciais de uma infecção bacteriana, são expressas preferencialmente as moléculas de superfície, responsáveis pelo importante processo de adesão e menos sensíveis à detecção pelo sistema imune (por não se espalharem pelo organismo). (39) Nesse mesmo momento, as moléculas extracelulares, mais importantes em etapas posteriores da infecção e mais facilmente detectadas pelo sistema imune (já que se espalham no corpo através da corrente sanguínea) são pouco expressas. Somente após o aumento do número de bactérias no processo infeccioso e, consequentemente, o acúmulo de auto-indutores, o sistema de quorum sensing é acionado e a expressão de moléculas de superfície é diminuída e as moléculas extracelulares são preferencialmente expressas. Assim, foi postulado que os sistemas de quorum sensing teriam como objetivo evitar a expressão prematura de fatores de virulência em bactérias. Estudos revelam que, para um processo infeccioso ser detectado pelo sistema imunológico, é necessária a presença no organismo de um número razoável de bactérias e de seus produtos. Além disso, quanto mais cedo um processo infeccioso é detectado, mais fácil e rápida será sua eliminação. (39-41)

Dessa forma, bactérias capazes de controlar sua expressão gênica e evitar a expressão precoce de seus fatores de virulência poderiam adiar o reconhecimento do processo infeccioso até que um número maior de bactérias esteja presente no organismo e, dessa maneira, possa vencer a batalha contra o sistema imune. Basicamente, a principal vantagem do uso de sistemas de quorum sensing por bactérias na regulação gênica seria a expressão de cada grupo de genes no momento mais benéfico para tais microrganismos. (36) 
Sabe-se hoje, que diversas características das bactérias são controladas por sistemas de quorum sensing. Isso inclui desde as características relacionadas com a defesa desses microrganismos (como a luminescência), até as essencialmente ofensivas ao hospedeiro (como a liberação de toxinas e enzimas capazes de provocar doenças). (38)

Uma bactéria na qual o papel do quorum sensing na regulação de genes é bastante compreendido é a $P$. aeruginosa. Embora esse organismo tenha um grande número de fatores de virulência muitos não são expressos constantemente, sendo sua expressão dependente da densidade celular. Essa espécie bacteriana apresenta dois sistemas principais de quorum sensing, cada um deles composto por dois genes principais que codificam uma enzima responsável pela síntese do auto-indutor (no caso uma AHL) e uma proteína $\mathrm{R}$, que responde ao auto-indutor. (37-39) Os complexos formados por auto-indutores e proteínas R desses dois sistemas controlam a expressão de genes necessários para a produção de enzimas, toxinas e produtos metabólicos secundários, como pigmentos. Além dessas características, os sistemas de quorum sensing presentes em $P$. aeruginosa regulam a formação de biofilmes promovendo uma maior resistência aos antibióticos. Muitas dessas características citadas são extremamente importantes para a patogenicidade desse microrganismo. $(39,40)$

\subsection{Pseudomonas aeruginosa}

Pseudomonas aeruginosa é uma bactéria pertencente à família das Pseudomonadaceae e caracteriza-se como bastonete reto ou ligeiramente curvo de 2 a $4 \mu \mathrm{m}$ de comprimento. É um microrganismo gram negativo, aeróbio estrito, podendo ser observado como células isoladas, aos pares, ou ainda em cadeias curtas, revelando mobilidade através de flagelo polar monotríqueo (em apenas um lado). (1)

Biofilmes formados por P. aeruginosa têm sido muito estudado, principalmente por sua facilidade em colonizar diversas superfícies em diferentes condições, e também por sua grande importância na área médica. (42) Células desta bactéria são capazes de se adaptar em

ambientes como aquáticos, no solo, associada a tecidos vivos, em plantas e animais. É uma bactéria patogênica e encontra-se frequentemente associada a infecções dos tratos urinário e respiratório em humanos. (43) As infecções por P. aeruginosa são também comuns em pacientes submetidos a tratamento por queimaduras severas ou outras lesões traumáticas de 
pele, bem como em indivíduos portadores de fibrose cística. A mesma não é considerada um patógeno obrigatório. Em vez disso, o organismo é oportunista, iniciando infecções em indivíduos que apresentam baixa resistência. (43-44)

A sua capacidade de adaptação em diferentes ambientes é devida em parte, a elevada porcentagem de reguladores transcricionais, regulado por Quorum Sensing. (45) Possibilitando inúmeras consequências como a regulação da produção de polissacarídeos, do fenótipo de biofilme, que ocasiona em uma maior virulência e resistência aos antibióticos. (46)

Uma estratégia apresentada por esta bactéria é a produção de diferentes tipos de polissacarídeos extracelulares. Estes por sua vez, fornecem as células uma maior tolerância à dessecação, agentes oxidantes, e proteção frente a processos defensivos. (27) Neste sentido, $P$. aeruginosa é capaz de formar três exopolissacarídeos (EPS), que são formados a partir da expressão de proteínas codificadas por agrupamentos de genes: alginato, psl (locus de síntese de polissacarídeo), rico em manose e pel (película), com estrutura e composição desconhecida. (27-28) Sendo que, o alginato é formado a partir de PA3540-PA3551 (no genoma FRD1) por um operon contendo 12 genes; psl a partir de PA2231- PA2242 (no genoma PA01) oriundo de um operon contendo também 12 genes; e o operon pel de PA3058PA3064 com 7 genes (no genoma PA14). (27)

Os alginatos são polímeros lineares não ramificados, polianiônicos, composto por polissacarídeo de subunidades não repetitivas, os ácidos urônicos, que apresentam elevado peso molecular. O mesmo é segregado para o meio circundante e não é covalentemente ligado à superfície da célula. $(27,47) \mathrm{O}$ alginato produzido por $P$. aeruginosa (FRD1), resulta em colônias com aparência altamente viscosa, podendo ser visualizado por microscopia de força atômica como uma estrutura gelatinosa, macia e densa, que rodeia as células (figura 2A). $\mathrm{O}$ alginato tem demonstrado contribuir para a diminuição da susceptibilidade de biofilmes ao tratamento com antibióticos e mecanismos antibacterianos de defesa do homem. (27)

O polissacarídeo psl é composto por pentâmeros de repetição de D-manose, Lramnose e D-glicose. Formando uma distribuição helicoidal que rodeia a superfície da célula de $P$. aeruginosa (PA01) (figura 2B), facilitando sua capacidade de desempenhar sua comunicação célula-célula e célula-superfície, durante a formação do biofilme. $(46,48)$ São 
comumente encontradas em pelo menos duas formas: uma com elevado peso molecular associada às células e a outra forma solúvel relativamente menor que pode ser isolado a partir de células livres de cultura sobrenadante. $(27,48)$ Psl é produzido durante o crescimento planctônico, mediando a adesão às superfícies e contribuindo para a formação de microcolônias. Em biofilmes maduros, psl está associado com a superfície das microcolônias, formando uma malha periférica abrangendo toda a região de cobertura. $(27,50)$

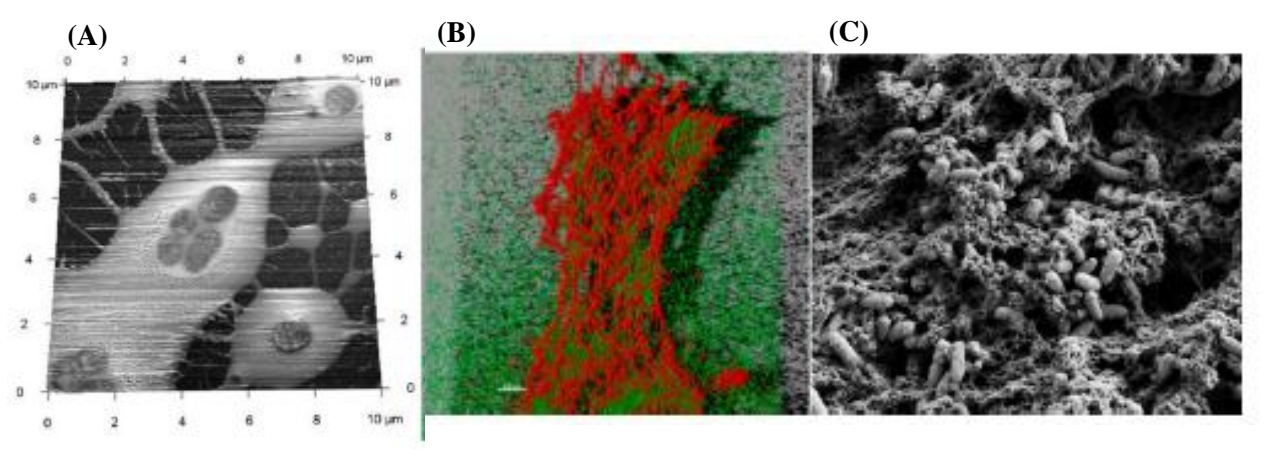

Figura 2 - Imagens de microscopia mostrando os três tipos de polissacarídeos envolvidos na formação de biofilmes em Pseudomonas aeruginosa. (A) alginato, (B) Psl e (C) Pel. (27)

Outro polímero requerido para a produção de polissacarídeo em $P$. aeruginosa (PA14) é o pel, que ao contrário do polissacarídeo psl, cuja estrutura foi prevista, sua composição e a natureza são indefinidos. (46) O polissacarídeo pel (figura 2C) foi descoberto por rastreio de uma biblioteca de transposição de mutantes de um tipo específico de biofilme, o qual se forma na interface ar-líquido de uma cultura bacteriana. (27) Além da formação de uma película, o pel promove adesão e agregação das culturas em cepas PA14 (28,51), ou quando, superexpresso em cepas PA01(49-50) independentemente de expressão psl. (43) O aumento da produção deste polímero também tem sido associado com o fenótipo de colônias enrrugadas. Recentemente, foi demonstrado que pel desempenha funções importantes na interação célula-célula, promovendo o arranjo estrutural para o início das fases de formação do biofilme. (27)

Semelhante à psl, o pel é produzido quando níveis intracelular de c-di-GMP são elevados.(27, 50) O mesmo, também precisa de alguns genes específicos para biossíntese completa de exopolissacarídeos, implicando que sua maquinaria pode funcionar com o auxílio de outras enzimas. Evidências recentes sugerem que pode haver cruzamento entre os fatores que afetam a produção do pel e $p s l$, onde a maior produção do pel ocorre na ausência do psl. 
O que sugere que ocorram comunicações cruzadas na regulação do loci dos polissacarídeos ou de competição para que os precursores limitem a produção de polissacarídeos individuais. (27) Geralmente, quando ambos ( $p s l$ e pel) estão presentes, estudos mostram que o psl é predominante, enquanto o pel tem um impacto limitado sobre o fenótipo do biofilme. No entanto, nos casos em que o operon psl está ausente ou é interrompido, tal como é em PA14, ou quando o nível de c-di-GMP é maximamente elevado, pel tem mais impacto na formação de biofilme. $(27,28,50)$

Portanto cada exopolissacarídeo fornece diferentes propriedades fisiológicas para as células e para toda matriz do biofilme. Em geral, $P$. aeruginosa produz predominantemente um polissacarídeo secretado a um dado momento, embora algumas cepas já sequenciadas tenha a capacidade genética de produzir todos os três polissacarídeos (alginato, psl e pel). $(27,47,50)$ Esta diversificação pode ser uma estratégia de sobrevivência desenvolvida pela comunidade de bactérias do biofilme, como uma maneira de suportar alterações das condições ambientais. (27)

\subsection{C-di-GMP: molécula sinalizadora em bactérias}

Com objetivo de aperfeiçoar a produção e pureza de celulose, em 1987, foi descoberto por Benziman e colegas o dinucleotídeo cíclico guanosina monofosfato (c-di-GMP). (20) Eles estudaram a base bioquímica da biossíntese de celulose em Gluconaceto bacterxylinus e descobriram um composto de baixo peso molecular e estável ao calor, que estimula a atividade da síntese de celulose. $(20,21)$ E esse mesmo dinucleotídeo foi reconhecido como um importante segundo mensageiro em bactérias, amplamente útil para o desenvolvimento de biofilme. $(24,52)$

Em geral, c-di-GMP estimula a biossíntese de adesinas, exopolissacarídeo, substâncias da matriz em biofilmes, inibe várias formas de motilidade, controla comutação entre a forma livre e sedentária associados aos estilos de vida de bactérias no biofilme. Além disso, c-diGMP controla a virulência de patôgenos em animais e vegetais, progressão através da célula e outras funções celulares. $(20,22,23)$

Sua síntese e degradação são catalisadas por diguanilato ciclases (DGCs) e fosfodiesterases (PDEs) (figura 3), respectivamente. Enquanto que a atividade das DGC foi 
atribuída às proteínas contendo o domínio GGDEF (Gly-Gly-Asp-Glu-Phe) a atividade enzimática responsável pela clivagem do c-di-GMP tem sido associada a proteínas que contêm os domínios EAL (Glu-Ala-Leu) e HD-GYP (His-Asp-Gly-Tyr-Pro). (52-53) O papel central destas enzimas na formação de biofilme torna um alvo ideal para o desenvolvimento de novos compostos anti-biofilme.

Sinais

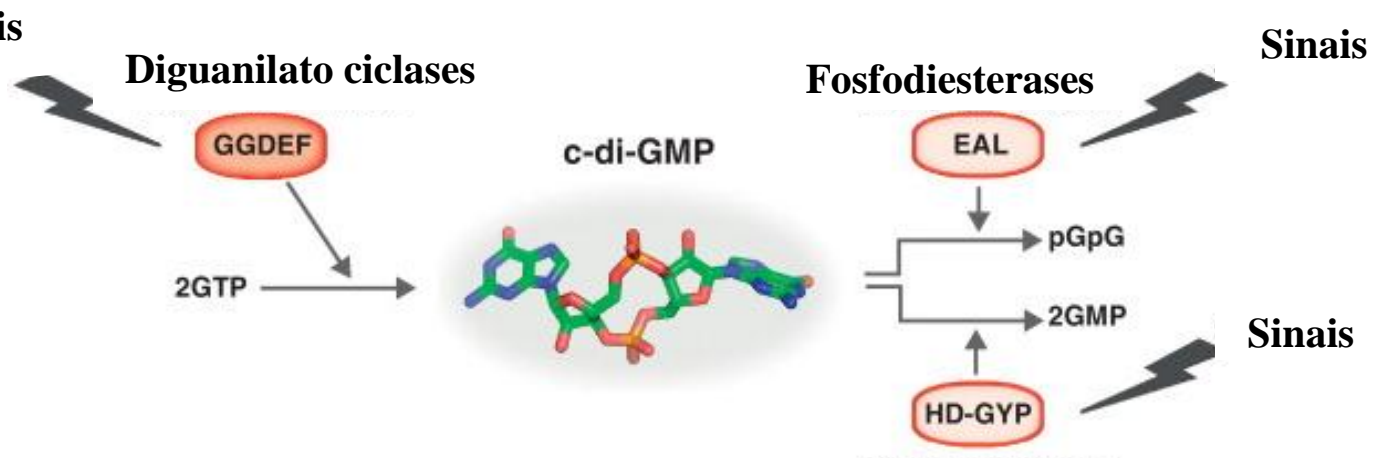

Fosfodiesterases

Figura 3- Esquema mostrando a síntese e a degradação de c-di-GMP. Sua síntese ocorre a partir de duas moléculas de GTP por proteínas Diguanilato Ciclases (DGCs) contendo o domínio GGDEF e sua degradação a 5'-fosfoguanil-(3'-5')-guanosina (pGpG) ocorre por meio de proteínas Fosfodiesterases (PDEs) contendo os domínios EAL ou HD-GYP Adaptado(21)

\subsubsection{Diguanilato ciclases}

Como já foi mencionado, c-di-GMP é sintetizado a partir de dois equivalentes de GTP por diguanilato ciclases (DGCs), que são caracterizadas pela presença de dois sítios, o sítio ativo (sítio-A) e um sítio inibitório (sítio-I). No seu sítio-A contém o motivo GGDEF ou GGEEF, correspondente aos os seguintes resíduos de aminoácidos (Gly-Gly-Asp-Glu-Phe) e (Gly-Gly-Glu-Glu-Phe), respectivamente. (52-53) Qualquer mutação pontual do motivo GGDEF elimina a atividade enzimática das proteínas DGCs. Já o sítio-I é caracterizado por um motivo RxxD, correspondente aos seguintes resíduos de aminoácidos (Arg-xx-Asp), onde o x pode ser qualquer resíduo de aminoácido. A ligação de c-di-GMP no sítio-I de DGCs inibe alostericamente a síntese de c-di-GMP (inibição pelo produto). Este sistema de modulação alostérica ajuda a evitar o consumo excessivo de GTP e, finalmente, limita a produção de c-di-GMP. (54) 
O primeiro exemplo de uma DGC contendo tanto um sítio-A e sítio-I foi a proteína PleD em C. crescentus. PleD possui dois domínios REC em "tandem” na porção N-terminal, seguidos pelo domínio GGDEF. Enquanto que um dos domínios REC (denominado de adaptador) é degenerado, o outro (denominado de ativador) possui todas as características essenciais, incluindo o sítio de fosforilação conservado, que modula a atividade de PleD. (5254)

Uma série de estudos bioquímicos e estruturais, incluindo as formas ativas e nãoativas de PleD mostraram que a ativação dessa enzima envolve um mecanismo de dimerização. O domínio GGDEF está ligado aos domínios REC por um "linker" flexível, sugerindo mobilidade dos domínios na mesma cadeia polipeptídica. A ativação da enzima através da fosforilação do resíduo Asp53 do domínio REC ativador promove um rearranjo estrutural, que em resposta induz uma dimerização através da porção não-catalítica da enzima. Este estado dimérico é um pré-requisito para o encontro produtivo e eficiente de dois domínios GGDEF complexados com GTP e consequente síntese de c-di-GMP. (54)

Outra característica interessante apresentada por PleD é a inibição não competitiva pelo produto c-di-GMP (tal característica tem sido observada para várias outras DGCs). Esse mecanismo de inibição ficou claro com a resolução das estruturas cristalográficas de PleD, onde foi observado que uma forma dimérica intercalada de c-di-GMP age como um mediador de interações inter-domínio e dessa forma previne que os dois motivos GGDEF se encontrem para formar o sítio ativo da enzima, ou seja, c-di-GMP promove uma inibição por imobilização dos domínios GGDEF. O sítio inibitório (sítio-I) é caracterizado pela presença de um motivo altamente conservado (onde os resíduos Arg e Asp interagem diretamente com c-di-GMP e pode ser qualquer aminoácido) separado do motivo GGDEF por cinco resíduos. Esse tipo de inibição limita a concentração de produto formado e previne o consumo indiscriminado do substrato, como já mencionado anteriormente. (54-55)

Diferentemente de PleD, a enzima WspR de P. aeruginosa possui apenas um domínio REC conservado na porção N-terminal, o qual está ligado ao domínio GGDEF através de uma longa hélice denominada de stalk. Embora a estrutura de WspR apresente estados funcionais similares às conformações de PleD complexadas com c-di-GMP, outras grandes diferenças estruturais sugerem um mecanismo de ação e inibição pelo produto distintos, o qual envolve 
diferentes formas oligoméricas. Enquanto que na estrutura monomérica de PleD, o sítio-I localiza-se na interface entre o domínio GGDEF e REC da mesma cadeia, a inibição pelo produto em WspR ocorre pela ligação de c-di-GMP no sítio inibitório formado na interface de dois domínios GGDEF de diferentes cadeias, sendo que um deles contribui com o motivo conservado e o outro com o resíduo Arg198. Esta característica também foi observada na forma ativada dimérica de PleD, mas análises estruturais e uma série de estudos bioquímicos sugerem que o mecanismo regulatório de WspR difere grandemente de PleD. Em resumo, tais estudos demonstraram que a ativação de WspR segue um ciclo que inclui um estado tetramérico transiente (o qual pode existir livre de c-di- GMP ou pode possuir o nucleotídeo complexado no sítio-I) e um forma dimérica elongada inativa (que contém c-di-GMP no sítio inibitório). Esse dímero pode ser reativado pela remoção de c-di-GMP do sítio-I pela ação de fosfodiesterases.(54-56)

Estes dois exemplos ilustram a grande quantidade de informações conhecidas a respeito da atividade enzimática e mecanismos regulatórios dos domínios GGDEF. No entanto, dado principalmente a grande flexibilidade encontrada nessa família de proteínas (conformação que é estabilizada com a ligação de c-di-GMP no sítio-I) e o caráter transitório do estado ativado da enzima, até hoje nenhuma estrutura da conformação dimérica cataliticamente competente de alguma DGC foi obtida.

\subsubsection{Fosfodiesterases}

As fosfodiesterases (PDEs) contendo o domínio HD-GYP hidrólisa c-di-GMP diretamente a GMP, enquanto as PDEs contendo o domínio EAL clivam c-di-GMP em pGpG e ainda em mais duas moléculas de GMP. Ambas as classes de PDEs requerem íons $\mathrm{Mg}^{2+}$ para a hidrólise, além disso, $\mathrm{Mn}^{2+}$ também pode ser substituído por $\mathrm{Mg}^{2}{ }^{+}$. Por outro lado, cátions como: $\mathrm{Ca}^{2+} \mathrm{Ni}^{2+}, \mathrm{Fe}^{2+}$ e $\mathrm{Zn}^{2+}$ inibem a atividade de PDEs. O mecanismo detalhado para a clivagem de c-di-GMP por PDEs ainda não está bem elucidado, no entanto algumas análises das estruturas cristalográficas de PDEs, com ou sem c-di-GMP ligado, têm fornecido algumas pistas sobre como c-di-GMP é clivado pelas fosfodiesterases. (53-55)

Por exemplo, as estruturas cristalinas de BlrP1 de K. pneumonia e TBD1265 de $T$. denitrificans revelam a presença de dois íons metálicos que estão ligados aos oxigênios do 
grupo fosfato de c-di-GMP, além de ânions hidróxidos e resíduos conservados de proteínas de domínio EAL (Asp- Glu-Asn). Yakunin e colaboradores propuseram que os íons metálicos no sítio ativo de PDEs estão envolvidos na ativação do ácido de Lewis do centro de fosfato, assim como a ativação da molécula de água de ligação (com ajuda de uma lisina vizinha para gerar um hidróxido catalítico), que, em seguida, ataca o centro de fosfato c-di-GMP para conduzir sua clivagem. (52-54)

Em contraste às PDEs contendo o domínio EAL, para a qual existem algumas estruturas cristalinas, as PDEs contendo o domínio HD-GYP, há ainda menos estruturas cristalográficas ressolvidas. Dentre elas, a proteína Bd1817 de B. bacteriovorus é o melhor modelo atualmente disponível para deduzir o mecanismo catalítico de clivagem de c-di-GMP por proteínas que contêm o domínio HD-GYP. Assim, a estrutura cristalina da Bd1817 revela a ligação dos oxigênios do grupo fosfato de c-di-GMP a um complexo binuclear central de íons de ferro que por sua vez, conectam-se a alguns resíduos conservados de HD-GYP. À medida que mais dados de alta resolução estrutural a respeito da atividade catalítica de HDGYP tornam-se disponíveis, melhor será o entendimento a respeito da estratégia usada por estas classes de enzimas para clivar ambas as porções de fosfato de c-di-GMP. (51-54)

\subsubsection{Polimorfismo de c-di-GMP}

Sabe-se que c-di-GMP apresenta polimorfismo em solução, e que o equilíbrio entre as espécies monoméricas, diméricas, tetraméricas, e octaméricas são afectadas pela presença de íons metálicos. No entanto, apenas as formas monoméricas e diméricas (figura 4) foram encontradas em condições fisiológicas, ao passo que a formação de oligômero ocorre somente na concentração de $\mathrm{mM}$ ou na presença de intercaladores aromáticos adicionais. (54-55) 


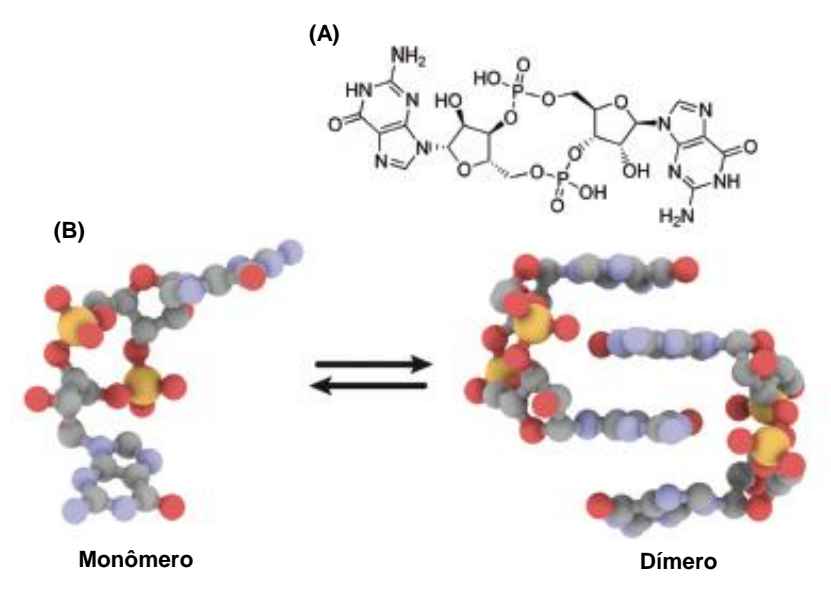

Figura 4- Estrutura química e estrutura 3D do monômero e do dímero de c-di-GMP. O equilíbrio em solução das duas espécies é afetado pela presença de sais monovalentes ou cátionss divalentes. Adapatado (55)

O equilíbrio monômero-dímero também pode está relacionado a um papel fisiológico, permitindo que as bactérias sintam e controlem diferentes concentrações locais de c-di-GMP. (55) Alguns receptores (tabela 2) como PilZ (56) pode ligar tanto o monômero de c-di-GMP, como na forma intercalada ou dímero.

Apesar do grande esforço para compreender as vias moleculares de sinalização de cdi-GMP pouco ainda se sabe. No entanto, com o advento do sequenciamento genômico aumentou drasticamente o interesse nestes sistemas. Resultando no reconhecimento de domínios GGDEF e EAL que não são apenas ubíquos em bactérias, mas também em outras espécies, podendo codificar um grande número de proteínas. $(20,54)$ Genes que codificam proteínas contendo os domínios envolvidos na biossíntese de c-di-GMP encontram-se dentro dos mais abundantes nos genomas bacterianos já sequenciados. De forma que, tal diversidade está relacionada com a capacidade de adaptação em diferentes nichos ecológicos, sendo que os patógenos oportunistas apresentam os maiores números de proteínas contendo os domínios GGDEF e/ou EAL por genoma. Proteínas contendo esses domínios geralmente aparecem associadas com outros módulos de sinalização, tais como os domínios reguladores de respostas, associados aos sistemas de dois componentes, ou domínios HAMP, sendo também comum a presença de domínios transmembrânicos. (54)

A manipulação artificial do conteúdo celular de c-di-GMP, proveniente da superprodução de proteínas contendo domínio GGDEF estimula fortemente a síntese de adesinas e componentes da matriz do biofilme além de interferir em funções de virulência e 
motilidade aguda, enquanto superprodução de proteínas de domínio EAL produz o oposto. (20-23) Estudos atuais estão atribuindo funções moleculares específicas para proteínas contendo os domínios GGDEF, EAL e HD-GYP e estão começando a revelar como estes sistemas estão integrados em redes reguladoras complexas. Mais recentemente foram encontradas proteínas contendo os domínios GGDEF e EAL que possuem os domínios DGC ou PDE conservados, mas são enzimaticamente inativos "degenerados", como a proteína PelD de $P$. aeruginosa, classificada como uma GGDEF degenerada. $(21,53)$

\subsubsection{Receptores de c-di-GMP}

Embora em número limitado, os receptores de c-di-GMP identificados e caracterizados até o momento apresentam uma grande diversidade (tabela 2).

Tabela 2 - Receptores específicos para c-di-GMP. Adaptado $(21,52,54)$

\begin{tabular}{ll}
\hline \multicolumn{1}{c}{ Proteínas } & Organismos \\
\hline Fatores de transcrição & \\
FleQ & P. aeruginosa \\
VpsT & V. cholera \\
Clp & Xantomonas campestris \\
Bcam1349 & Xantomonas axopodis \\
Proteínas contendo o domínio PilZ & Burkholderia cenocepacia \\
YcgR & \\
DcgR & E. coli \\
Alg44 & C. crescentus \\
PlzD & P. aeruginosa \\
MrkH & Vibrio cholera \\
Proteínas contendo domínios GGDEF e/ou EAL inativos & Klebsiella pneumoniae \\
FimX & \\
LapD & P. aeruginosa \\
PelD & P. fluorescens \\
PopA & P. aeruginosa \\
Outros & C. crescentus \\
PNPase & \\
Riboswitches & E. coli \\
Classe I & \\
Classe II & V. cholerea \\
\hline
\end{tabular}

Um dos primeiros domínios relacionados à ligação com c-di-GMP, foi identificado em proteínas envolvidas na síntese de celulose bacteriana, denominado PilZ (56), que serviu de 
base para identificação de todos os outros. A recente identificação de duas classes de receptores de c-di-GMP, denominados Riboswiches (57) em vários mRNAs, adiciona um novo nível de complexidade nas funções desempenhadas por c-di-GMP. Além disso, informações estruturais a respeito do modo preciso de ligação de c-di-GMP limitam-se ao domínio PilZ altamente divergente (56) e ao domínio EAL degenerado de FimX, (20-21) bem como os sítios-I regulatórios presentes em algumas proteínas com domínios GGDEF ativos. (53)

Dessa forma, investigações futuras serão necessárias para determinar se a sinalização mediada por c-di-GMP limita-se a um pequeno número de motivos de ligação universal ou se os receptores individuais evoluíram os modos específicos para o reconhecimento de c-diGMP. A elucidação destes sistemas de sinalização mediados por esse dinucleotídeo, juntamente com seus respectivos receptores estão diretamente relacionados com respostas celulares. No entanto, os mecanismos subjacentes a estes processos moleculares, e em particular os alvos diretos que são afetados por c-di-GMP estão apenas começando a emergir. $(21,24)$ Sendo assim, os receptores de c-di-GMP representam uma parte crucial nos circuitos de sinalização bacteriana e, portanto, representam valiosos alvos para o desenvolvimento de novas terapias.

\subsection{Proteína PelD de Pseudomonas aeruginosa (PA14)}

O primeiro receptor de c-di-GMP amplamente caracterizado inclui proteínas que apresentam o domínio PilZ. (21-23) No entanto, é provável que o número de diferentes domínios que se ligam a c-di-GMP pode ser muito maior do que aqueles com domínios PilZ. Existem evidências para a existência de outras proteínas sem os domínios PilZ, que são capazes de se ligar a c-di-GMP, incluindo o sítio inibitório (sítio-I) de muitas DGCs e todas as PDEs que se ligam e hidrolisam o dinucleótido. (26)

Uma análise sistemática dos genes de $P$. aeruginosa que codifica DGCs e PDEs identificou um fenótipo que não podia está ligado a proteínas conhecidas que contêm um domínio PilZ. (26) Nestes estudos, um aumento da expressão de DGCs levou a um aumento nos níveis de c-di-GMP e a consequente formação de comunidades multicelulares na interface 
ar-superfície de uma cultura bacteriana, na forma de uma película. A formação dessa película em biofilmes de $P$. aeruginosa requer proteínas codificadas pelo operon pel. No entanto, nenhuma proteína codificada por esse operon, possui o domínio PilZ, o que sugere uma nova classe de proteínas possam vir a atuar como receptores de c-di-GMP. $(26-27,56)$

Após a confirmação de que expressão dos genes pel é necessária para a produção de polissacarídeo em $P$. aeruginosa, investigou-se então através de quais mecanismos essa poderia ser induzida. (26) Um deles ocorre através de histidina kinases (RetS), que são capazes de agir em oposição as formas GacA/ GacS, sistema de dois componentes. Esse sistema por sua vez, controla a transcrição de dois pequenos RNAs reguladores (RsmY e RsmZ) levando a uma diminuição ou aumento da tradução dos transcritos do operon pel na presença de RetS ou LadS, respectivamente. (26) O outro mecanismo ocorre quando os níveis de c-di-GMP aumentam, ocorrendo um aumento da transcrição e expressão de proteínas do operon pel. (27)

Uma análise sistemática da sequência das proteínas codificadas pelo operon pel utilizando as ferramentas de bioinformática, mostrou que dentre todas as proteínas codificadas por esse operon a única que apresentou os resíduos obrigatórios para ligação com c-di-GMP foi a proteína PelD. Além disso, estudos mostraram que a expressão de PelD e a sua ligação específica com c-di-GMP são necessários para produção do polissacarídeo pel. O estudo mostrou ainda que PelD não apresentou qualquer semelhança em sua sequência primária ou estrutura secundária com o conhecido domínio de ligação a c-di-GMP, o PilZ. Ao invés disso, encontrou-se o motivo RxxD, o mesmo motivo conservado no sítio-I de PleD de Caulobacter crescentus. Sendo assim, observou-se que o motivo de ligação a c-di-GMP em PelD é semelhante ao sítio-I de DGCs, mas diferente do sítio-A, pois não apresenta o motivo GGDEF conservado, no lugar desses resíduos encontram-se os resíduos RNDEG (29-30), o que indica que essa proteína é um receptor de c-di-GMP do tipo GGDEF degenerado, pois não apresenta os resíduos necessários para ser uma DGC ativa. A identificação de uma nova família de proteínas ligadoras de c-di-GMP permite a compreensão da diversidade biológica deste dinucleótido. (26-27)

Assim, o operon pel que codifica proteínas com funções de biossíntese do polissacarídeo pel é composto por sete genes que codificam as proteínas: Pel A-G, as quais são responsáveis pela síntese e exportação do polissacarídeo pel. (26,27) Análises 
computacionais e funcionais revelaram a presença tanto de proteínas solúveis (PelA e PelF citosólica; PelC - periplasmática) quanto associadas à membrana celular (PelB - membrana externa; PelD e PelE - proteínas da membrana interna com grandes domínios citosólicos; PelG - proteína da membrana interna com doze segmentos transmembranares) (figura 5). (27)

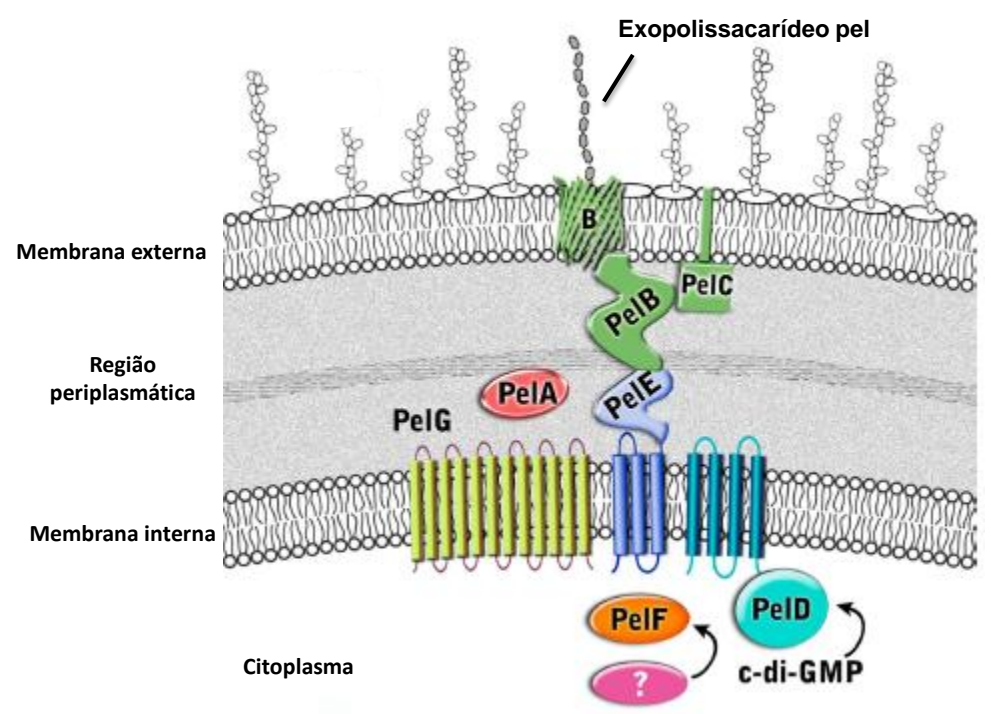

Figura 5 - Modelo de interação entre os complexos proteicos codificados pelo operon pel em Pseudomonas aeruginosa. Adaptado (27)

Pouco ainda se sabe sobre a biossíntese do polissacarídeo pel, pois até agora, apenas duas proteínas (PelC e PelD) codificadas pelo operon pel, foram examinadas experimentalmente. Além disso, foi proposto o modelo de apenas uma delas, a proteína PelB, como pode ser observado na figura acima. Esse esquema de interação proteica mostrado na figura 5 foi baseado em dados de bioinformática, através de análises de homologia estrutural de todas as proteínas codificadas pelo operon pel (PelA- PelB- PelC- PelD- PelE- PelF e PelG). O modelo proposto por Howel et al, (2011) sugere que a biossíntese do pel é mais estreitamente relacionada com as vias de biossíntese de alginato e celulose bacteriana, do que para a produção de cápsula, mas é notável que o polissacarídeo é distinto dos mecanismos propostos atualmente para estes sistemas de secreção. Neste sentido são necessárias mais investigações experimentais a respeito de todas as interações proteicas envolvidas na síntese, exportação e polimerização do até então descaracterizado polissacarídeo pel, um dos principais motivos de resistência bacteriana no biofilme de $P$. aeruginosa. 


\section{Papitulo 3}

3 Chateriais e Chétodos

Neste capítulo serão apresentadas as principais técnicas utilizadas durante este trabalho. Além de mostrar como foi desenvolvida cada etapa experimental para obtenção e caracterização da proteína PelD. 


\subsection{MATERIAIS E MÉTODOS}

Frente ao processo empírico de cristalização, bem como uma melhor caracterização biofísica, houve a necessidade de produzir várias construções da proteína recombinante PelD de Pseudomonas aeruginosa (PA14), correspondente apenas a sua região citoplasmática, expressa em E. coli. BL21(DE3).

\subsubsection{Análise da proteína PelD de Pseudomonas aeruginosa (PA14) por meio de ferramentas de bioinformática}

A predição in silico de propriedades das proteínas tem-se mostrado bastante útil na sua investigação estrutural e funcional, assim como, um bom guia para o trabalho experimental. Com a sequência primária da proteína, ou seja, sua sequência de aminoácidos é possível fazer predições acerca de suas estruturas secundárias, hélices transmembranares, peptídeo sinal, coiled-coils, domínios conservados, ponto isoelétrico teórico, massa molecular teórica, entre outras.

A análise teórica dos parâmetros físico-químicos da proteína PelD de $P$. aeruginosa (PA14) foi realizada através da ferramenta ProtParam do servidor ExPASy. (58) Também foi realizada uma análise utilizando o programa HMMTOP (59) (http://www.sacs.ucsf.edu/cgibin/hmmtop.py). Este programa analisa a sequência primária da proteína predizendo as possíveis hélices transmembranares que ela possui, através da determinação das suas regiões hidrofílicas e hidrofóbicas. Adicionalmente, foi realizada uma predição de estruturas secundárias de PelD, usando o programa PSIPRED (60) (http://bioinf.cs.ucl.ac.uk/psipred/). Também foi realizada uma análise de domínios conservados através do programa Phyre server (61) (http://www.sbg.bio.ic.ac.uk/phyre), o mesmo análisa estruturas secundárias, bem como domínios conservados baseado em estruturas depositadas no PDB. Para as predições de coiled-coil foi usado o programa MARCOIL (62) (http://toolkit.tuebingen.mpg.de/marcoil), que retorna um gráfico mostrando a probabilidade de os resíduos em questão estarem em coiled-coil em função do número de resíduos. 


\subsubsection{Amplificação dos genes e delimitação das construções}

Com base na sequência de nucleotídeos do gene da PelD de Pseudomonas aeruginosa (PA14), como também nas predições de estruturas secundárias foram sintetizados oligonucleotídeos para várias construções diferentes de PelD ${ }^{\text {cito }}$. Isso foi feito para promover um melhor estudo das características estruturais da proteína, assim como aumentar a probabilidade de sucesso no processo de cristalização. Desta maneira, os oligos sintetizados apresentavam sítios de clivagem para enzimas de restrição especificas (tabela 3). Nesta etapa, foram utilizados os programas Custom Primers Oligo - Perfect $^{\mathrm{TM}}$ Designer (LifeTechnologies $^{\mathrm{TM}}$ ) e NEBcutter V2.0 (BioLabs) para desenhar os iniciadores (do inglês, primers), verificação dos sítios de clivagem e cálculo das temperaturas de anelamento e porcentagem de guanina $(\mathrm{G})$ e citosina $(\mathrm{C})$.

Tabela 3 - Oligonucleotídeos desenhados para clonagem das diferentes construções de PelD de Pseudomonas aeruginosa (PA14). As bases em vermelho correspondem aos sítios de reconhecimento das enzimas de restrição selecionadas.

\begin{tabular}{|c|c|c|c|}
\hline Código & $\begin{array}{l}\text { Arquitetura dos } \\
\text { domínios }\end{array}$ & $\begin{array}{l}\text { Oligonucleotídeos } \\
\text { (5'-3') fwd-rev }\end{array}$ & $\begin{array}{l}\text { Vetor / enzimas de } \\
\text { restrição }\end{array}$ \\
\hline PelD ${ }^{111-455}$ & GAF/GGDEF & $\begin{array}{l}\text { CAGTGAGCTCCGCGACATCTG GGAACG } \\
\text { CAGTCTCGAGCTAAACAGCCACTTGCTGAT CAT TC }\end{array}$ & peTSUMO/(SacI-XhoI) \\
\hline PelD ${ }^{176-455}$ & GAF/GGDEF & $\begin{array}{l}\text { CAGTGAATTCGGCGATGAGGCACCG } \\
\text { CAGTCTCGAGCTAAA CAG CCACTTGCTGATCAT TC }\end{array}$ & peTSUMO/(EcoRI-XhoI) \\
\hline PelD $^{180-455}$ & GAF/GGDEF & $\begin{array}{l}\text { CAGTGAATTCCCGCTCGATGCGCTG } \\
\text { CAGTCTCGAGCTAAACAGCCACTTGCTGATCAT TC }\end{array}$ & peTSUMO/(EcoRI-XhoI) \\
\hline PelD ${ }^{176-320}$ & GAF & $\begin{array}{l}\text { CAGTGAATTCGGCGATGAGGCACCG } \\
\text { CAGTCTCGAGTCACGATGTCGGCCAGTTGC }\end{array}$ & peTSUMO/(EcoRI-XhoI) \\
\hline PelD ${ }^{176-317}$ & GAF & $\begin{array}{l}\text { CAGTGAATTCGGCGATGAGGCACCG } \\
\text { CAGTCTCGAGTCACCAGTTGCAGTGCGCG }\end{array}$ & peTSUMO/(EcoRI-XhoI) \\
\hline PelD ${ }^{176-314}$ & GAF & $\begin{array}{l}\text { CAGTGAATTCGGCGATGAGGCACCG } \\
\text { CAGTCTCGAGTCACAGTGCGCGACGGTC }\end{array}$ & peTSUMO/(EcoRI-XhoI) \\
\hline PelD ${ }^{180-320}$ & GAF & $\begin{array}{l}\text { CAGTGAATTCCCGCTCGATGCGCTG } \\
\text { CAGTCTCGAGTCACGATGTCGGCCAGTTGC }\end{array}$ & peTSUMO/(EcoRI-XhoI) \\
\hline PelD $^{180-317}$ & GAF & $\begin{array}{l}\text { CAGTGAATTCCCGCTCGATGCGCTG } \\
\text { CAGTCTCGAGTCACCAGTTGCAGTGCGCG }\end{array}$ & peTSUMO/(EcoRI-XhoI) \\
\hline PelD ${ }^{180-314}$ & GAF & $\begin{array}{l}\text { CAGTGAATTCCCGCTCGATGCGCTG } \\
\text { CAGTCTCGAGTCACAGTGCGCGACGGTC }\end{array}$ & peTSUMO /(EcoRI-XhoI) \\
\hline PelD $317-455$ & GGDEF & $\begin{array}{l}\text { CAGTGGATCCGCCGACATCGACGCC } \\
\text { CAGTCTCGAGCTAAACAGCCACTT GCTGATCAT TC }\end{array}$ & peTSUMO /(BamHI-XhoI) \\
\hline PelD $320-455$ & GGDEF & $\begin{array}{l}\text { CAGTGGATCCGACGCCCAGCGCTTC } \\
\text { CAGTCTCGAGCTAAACAG CCACTTGCTGATCATTC }\end{array}$ & peTSUMO/(BamHI-XhoI) \\
\hline
\end{tabular}


Para amplificação das construções listadas na tabela 3, foram feitas reações de PCR (Reação em Cadeia da Polimerase) a partir do DNA genômico de P. aeruginosa (PA14), contendo: $2 \mu \mathrm{L}$ de DNA (90 ng/ $\mu \mathrm{L}), 5 \mu \mathrm{L}$ de cada primer $(20 \mathrm{pmol} / \mu \mathrm{L}), 1 \mu \mathrm{L}$ de dNTP $_{\mathrm{MIX}}$ $(10 \mathrm{mM}), 0,5 \mu \mathrm{L}$ da enzima High fidelity (Invitrogem) $(5 \mathrm{U} / \mu \mathrm{L}), 5 \mu \mathrm{L}$ dotampão da enzima (10X) e quantidade suficiente de água MiliQ para $50 \mu \mathrm{L}$ de volume final. A reação foi submetida a um programa de PCR (tabela 4), executado no Termociclador (Eppendorf Mastercycler). Este programa foi montado para realizar 30 ciclos de amplificação realizando aberturas das fitas de DNA a $94^{\circ} \mathrm{C}$, seguida por uma redução até $60^{\circ} \mathrm{C}$ para hibridização dos oligos e posterior complementação das fitas a $72^{\circ} \mathrm{C}$ pela enzima High Fidelity (Invitrogen). Com duração de 2:30 h.

Tabela 4 - Programa de PCR executado para amplificação das construções de PelD de $P$. aeruginosa (PA14)

\begin{tabular}{ccccccc}
\hline $\begin{array}{c}\text { Número de } \\
\text { repetições }\end{array}$ & $\mathbf{1 x}$ & & $\mathbf{3 0 x}$ & $\mathbf{1 x}$ & $\mathbf{1 x}$ \\
\hline $\mathrm{T}^{\circ} \mathrm{C}$ & 94 & 94 & 60 & 72 & 72 & 4 \\
Tempo & 3, & $30 "$ & $30^{\prime}$ & 3, & 10, & $\infty$ \\
\hline
\end{tabular}

\subsubsection{Clonagem dos genes de PelD em vetor de expressão pET-SUMO (Invitrogen)}

A clonagem foi realizada diretamente no vetor de expressão, pET-SUMO (Invitrogen) (figura 6) que produz uma proteína de fusão com 6xHis-SUMO no N-terminal. Os sítios utilizados para a clonagem das proteínas de estudo foram os das endonucleases descritas na tabela 3 . 


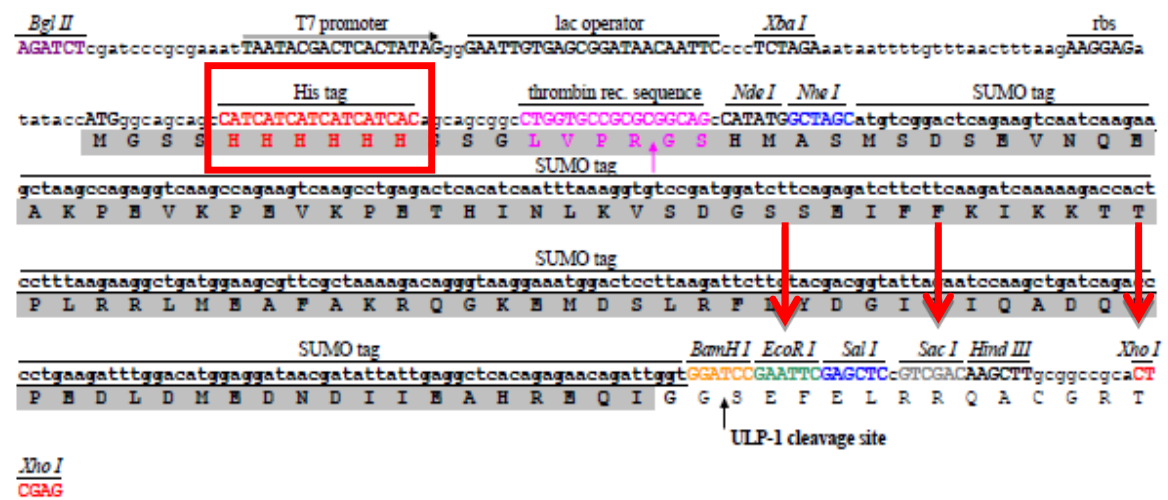

CGAG

Figura 6 - Mapa do vetor pET-SUMO. Este vetor codifica uma proteína de fusão chamada SUMO (13657,3Da), que se apresenta fusionada a cauda de histidina (6xHis-tag) e possui um sítio de clivagem (ULP-1) específico para a proteína Sumo protease.

Os produtos resultantes das amplificaçõesda reação de PCR foram analisados por eletroforese em gel de agarose $(1 \%$ em TAE com brometo de etídeo $10 \mathrm{mg} / \mathrm{mL})$ e tanto o vetor quanto o inserto foram purificados utilizando o kit Wizard Genomic DNA Purification (Promega) e digeridos com as endonucleases adequadas. Foram realizadas reações de digestão contendo: $20 \mu \mathrm{L}$ do produto amplificado/20 $\mu \mathrm{L}$ do vetor, $1 \mu \mathrm{L}$ de cada endonuclease adequada, $3 \mu \mathrm{L}$ do tampão Fast digest (10x) e quantidade suficiente de água MiliQ para $30 \mu \mathrm{L}$ de volume final.A reação de digestão foi mantida na estufa a $37{ }^{\circ} \mathrm{C}$ por 4 horas.Os produtos digeridos foram purificados utilizando o kit Wizard Genomic DNA Purification (Promega) e analisados em gel de agarose $1 \%$.

Estes fragmentos digeridos foram ligados por meio da seguinte reação: $1 \mu \mathrm{L}$ do vetor digerido ( $20 \mathrm{ng} / \mu \mathrm{L}$ ), 0,5 da enzima T4DNA ligase (razão molar 3:1, inserto: vetor), $1 \mu \mathrm{L}$ do tampão da enzima T4DNA ligase (10x), $3 \mu \mathrm{L}$ do inserto digeridoe quantidade suficiente de água MiliQ para $10 \mu \mathrm{L}$ de volume final. O sistema foi mantido no intervalo de temperatura $16^{\circ} \mathrm{C}$ a $26^{\circ} \mathrm{C}$ overnight.

\subsubsection{Transformação em E. coli DH5a}

A mistura de ligação foi utilizada na transformação de células competentes de $E$. coli $\mathrm{DH} 5 \alpha$, previamente preparadas através do método do cloreto de cálcio $\left(\mathrm{CaCl}_{2}\right)$. Isso ocorreu 
por meio da mistura de $3 \mu \mathrm{L}$ do produto de ligação com $50 \mu \mathrm{L}$ de células competentes de $E$. coli DH5 $\alpha$, a qual permaneceu em repouso no gelo por 30 minutos. Em seguida a mistura foi submetida a um choque térmico em banho-maria a $42^{\circ} \mathrm{C}$ por 2 minutos, retornando para o gelo por mais 5 minutos. Após o choque térmico, foram adicionados $300 \mu \mathrm{L}$ do meio S.O.C. (triptona 2\%/ extrato de levedura 0,5\%/ NaCl $10 \mathrm{mM} / \mathrm{KCl} 2,5 \mathrm{mM} / \mathrm{MgSO}_{4} 10 \mathrm{mM}$, glicose $20 \mathrm{mM}, \mathrm{pH}$ 7,4). Este sistema foi incubado a $37^{\circ} \mathrm{C}$ sob agitação por $1 \mathrm{~h}$. Terminado o período de incubação espalhou-se a reação em placas de petri contendo $20 \mathrm{~mL}$ de meio LB sólido com canamicina $(50 \mu \mathrm{g} / \mathrm{mL})$. As placas foram incubadas durante 16 horas a $37^{\circ} \mathrm{C}$.

O gene de resistência a canamicina permitiu o crescimento de colônias a partir de células que assimilaram o plasmídeo durante o choque térmico. Assim, algumas colônias foram selecionadas e transferidas para $5 \mathrm{~mL}$ do meio $\mathrm{LB}$ contendo o mesmo antibiótico e incubadas a $37^{\circ} \mathrm{C}$ com agitação por 16 horas. Após o crescimento de colônias isoladas, grandes quantidades de plasmídeos recombinantes foram extraídas por lise alcalina no sistema SV MINIPREP (Promega). A confirmação da ligação foi feita por teste de digestão com as enzimas de restrição adequadas e verificados a partir do gel de agarose $1 \%$.

Os clones positivos de cada construção foram submetidos ao sequenciamento dos nucleotídeos pelo método de terminação de cadeia por di-deoxinucleotídeos, utilizando o sequenciador automático 3130 Genetic Analyzer (Applied Biosystems). O resultado do sequenciamento foi analisado pelo programa SeqMan (63) pertencente ao pacote do software Lasergene Sequence Analysis Software (DNAStar), para confirmação do alinhamento da sequência obtida em comparação com a sequência disponível no banco de dados e possíveis presença ou ausência de mutações.

\subsubsection{Expressão das proteínas recombinantes}

Para expressão em larga escala das construções de PelD realizadas neste trabalho, fezse pré-inóculos das colônias transformantes em $5 \mathrm{~mL}$ de meio Lúria-Bertani (LB) contendo canamicina $(50 \mu \mathrm{g} / \mathrm{mL})$ incubando sob agitação por 16 horas a $37^{\circ} \mathrm{C}$. Posteriormente transferiu-se todo o conteúdo do pré-inóculo para um inóculo $(1000 \mathrm{~mL})$, o qual permaneceu sob agitação a $160 \mathrm{rpm} / 37^{\circ} \mathrm{C}$, até atingir uma D.O.600nm entre 0,4 e 0,6. Em seguida, foi 
acrescentado ao meio $0,5 \mathrm{mM}$ do agente indutor IPTG (isopropil- $\beta$-D-galactopiranosídeo) e as culturas foram mantidas por mais 16 horas em agitação constante a $18^{\circ} \mathrm{C}$.

Após o período de indução as células foram sedimentadas por centrifugação (4000 $\mathrm{rpm}, 30 \mathrm{~min}$ à $4^{\circ} \mathrm{C}$ ) e descartou-se o sobrenadante. O pellet foi ressuspendido em $20 \mathrm{~mL}$ do tampão de lise (Tris-HCl $25 \mathrm{mM}$ (pH 8,0)/ $\mathrm{NaCl} 500 \mathrm{mM} /$ imidazol $5 \mathrm{mM}$ ). Em seguida as células foram tratadas com lisozima (10 mg/L de cultura) em banho de gelo e submetidas a uma lise por ultra-som (sonicação). O extrato bruto foi submetido à centrifugação (10000 rpm, 40 min à $4^{\circ} \mathrm{C}$ ) e a porção solúvel foi utilizada no processo de purificação.

\subsubsection{Purificação por cromatografia de afinidade por metal imobilizado (IMAC)}

A técnica de IMAC baseia-se na afinidade diferencial que íons metálicos imobilizados em uma matriz sólida apresentam por certos grupamentos expostos na superfície de uma molécula em solução. (64) Esta afinidade resulta de ligações de coordenaçãoreversíveis formadas entre um íonmetálico quelado (o centro de adsorção) e certos resíduos de aminoácidos, tais como imidazol da histidina, tiol da cisteína e indol do triptofano, os quaisdoam elétrons para o íonmetálico, ou seja, atuam como base de Lewis. (64-65)

A clonagem do gene que codifica a proteína PelD em vetor de expressão pET-SUMO (Invitrogen), levou à expressão de uma proteína Sumo (66) fusionada a uma cauda de seis histidinas no seu N-terminal (figura 7), possibilitando a utilização da técnica de cromatografia por afinidade, neste caso o metal imobilizado foi o íon $\mathrm{Co}^{2+}$. Assim, ocorre a interação reversível entre os resíduos do aminoácido histidina da cadeia polipeptídica e o íon metálico $\mathrm{Co}^{2+}$ imobilizado em coluna Talon (Clontech), sendo possível separar a proteína fusionada de outras proteínas existentes no extrato bruto. O composto químico imidazol foi utilizado para realizar a eluição da proteína que interage com a resina contendo íons $\mathrm{Co}^{2+}$, já que o anel imidazólico tem maior afinidade química para ligação a esses íons e pode competir com os resíduos de histidina pela ligação. 


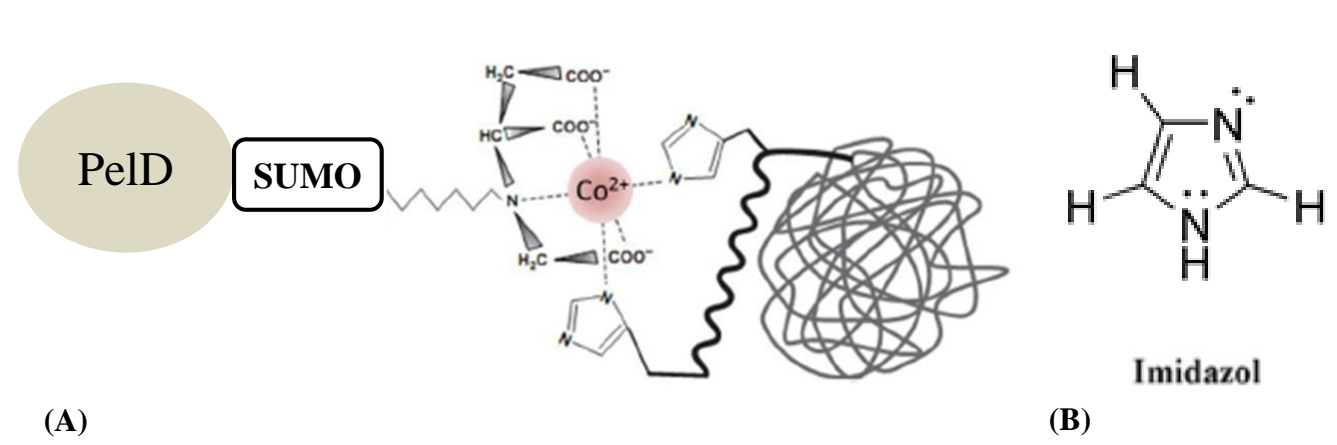

Figura 7 - Esquema ilustrando a cromatografia de afinidade por metal cobalto. (A) Interação da cauda de histidina com a proteína Sumo que por sua vez, está ligada a proteína PelD, presente na fase móvel com o metal quelado na resina da fase estacionária, permitindo recuperar de maneira seletiva a proteína de interesse. (B) Estrutura do imidazol, que compete com as histidinas pela interação com o cobalto. Adaptado. (67)

Para as purificações em larga escala a coluna foi empacotada com $5 \mathrm{~mL}$ de resina, previamente lavada com água mili-Q e em seguida, equilibrada com 5 volumes de coluna (VC) de tampão de lise (Tris-HCl $25 \mathrm{mM}(\mathrm{pH} 8,0) / \mathrm{NaCl} 500 \mathrm{mM} /$ imidazol $5 \mathrm{mM}$ ). O sobrenadante proveniente da lise bacteriana foi filtrado e aplicado na coluna cromatográfica de afinidade Talon (Clontech), que posteriormente foi lavada com tampão de lise e eluída com concentrações crescentes de imidazol (10, 20, 50, 100, 250 e 500 mM).

As frações correspondentes às eluições com maior grau de pureza foram diluídas em tampão (Tris- $\mathrm{HCl} 25 \mathrm{mM}(\mathrm{pH} \mathrm{8,0)/} \mathrm{NaCl} 500 \mathrm{mM}$ ) e concentradas em filtros Amicon Ultra (Milipore) de $15 \mathrm{~mL}$ com poro de 30.000 NMWL (Nominal Molecular Weight Limit) a 3000 rpm, $4^{\circ} \mathrm{C}$. Em seguida as amostras concentradas foram submetidas a uma coluna Desalting (HiPrep 26/10) (GE) pré-equilibrada com tampão (Tris-HCl 25 mM (pH 8,0)/ NaCl 500 mM), para retirada do imidazol. As frações do pellet, sobrenadante, não ligado, lavagem e eluições com gradiente de imidazol foram analisadas por SDS-PAGE $15 \%$.

\subsubsection{Clivagem da proteína de fusão (6xHis-Sumo) utilizando a protease ubiquitin-like proteins (ULP 1) de Saccharomyces cerevisiae}

A clivagem da proteína de fusão (13657 Da) (figura 8) foi realizada à temperatura ambiente por $1 \mathrm{~h}$, usando a sumo protease (26595 Da) (66) na proporção adequada. Essas 
proteínas são extremamente eficientes na clivagem de proteínas fusionadas com SUMO

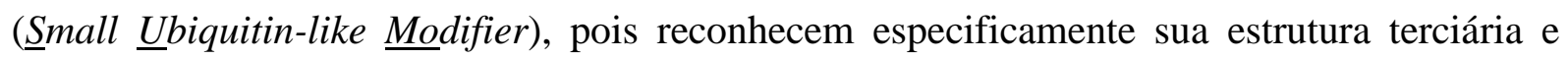
clivam uma sequência específica adjacente ao C-terminal, o que minimiza a clivagem dentro da proteína de interesse. (66)

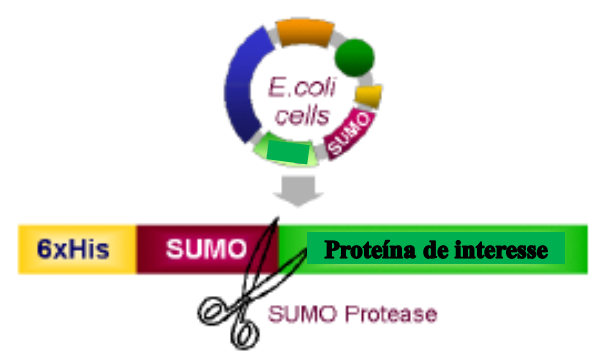

Figura 8-Clivagem da proteína de fusão 6xHis-Sumo pela Sumo protease.Adaptado (66)

Para que a clivagem ocorresse de maneira efetiva foi necessário medir a concentração da proteína PelD, para realizar os cálculos numa proporção de 1:30. A concentração de PelD foi medida utilizando-se o espectrofotômetro Nanodrop ${ }^{\mathrm{TM}} 1000$ (Thermo Scientific), com base na absorbância em $280 \mathrm{~nm}$, usando os coeficientes de extinção molar teórico $(\varepsilon)$ adequado para cada construção de PelD, por meio da Lei de Beer-Lambert. $(65)$

$$
A=\varepsilon \cdot c \cdot l
$$

Onde: A, é a absorbância da amostra, $\varepsilon$ é o coeficientede extinção molar teórico, c é a concentração da amostra (M) e 1 é o caminho óptico percorrido pela luz (cm). A concentração da proteína ULP 1 (produzida no laboratório), foi obtida através do método de Bradford (68), uma técnica utilizada na determinação de proteínas totais que utiliza o corante Coomassie brilliant blue BG-250.

Uma vez que tanto a proteína de fusão SUMO como a ULP 1 possuem uma cauda de 6xHis, a mistura foi novamente submetida a uma coluna de afinidade, onde houve a separação da proteína de fusão SUMO, ULP 1 e PelD recombinante clivada. As amostras eluídas contendo a PelD não-clivada e clivada, lavagens e eluição da Sumo e ULP 1 foram analisadas por SDS-PAGE $15 \%$. 


\subsubsection{Purificação por cromatografia de exclusão por tamanho}

$\mathrm{Na}$ cromatografia de exclusão por tamanho, as moléculas são separadas de acordo com diferenças em seus tamanhos e formas moleculares. A matriz da coluna é composta por um polímero com poros de tamanhos diferentes, onde proteínas com maior massa molecular migram mais rápido, pois tendem a passar direto pela matriz sem penetrar nos poros da resina, enquanto que moléculas com menor massa molecular tendem a penetrar nos poros da resina e migram mais lentamente através da coluna. (65)

Nesta etapa final de purificação, foi utilizada uma coluna Superdex 75 10/300 (GE) acoplada ao sistema de cromatografia AKTA (GE). A amostra de proteína, após a clivagem, foi aplicada na coluna previamente equilibrada com tampão (Tris- $\mathrm{HCl} 25 \mathrm{mM}(\mathrm{pH} 8,0) / \mathrm{NaCl}$ $500 \mathrm{mM}$ ). O fluxo de corrida foi de $0,5 \mathrm{~mL} / \mathrm{min}$ e a purificação foi monitorada a $280 \mathrm{~nm}$. As frações eluídas foram analisadas em gel SDS-PAGE 15\% e as amostras resultantes foram concentradas e utilizadas nos estudos biofísicos e cristalográficos.

\subsubsection{Produção enzimática do ligante c-di-GMP a partir da proteína YdeH, uma diguanilato ciclase}

A produção enzimática do c-di-GMP foi adaptada de Zähringer e colaboradores, na qual foi utilizado a diguanilato ciclase $\mathrm{YdeH}$ de Escherichia coli, produzida no próprio laboratório pelos colegas de grupo. Essa enzima possui no N-terminal um domínio com função desconhecida e no C-terminal o domínio GGDEF ativo. (69)

A proteína YdeH, cuja atividade catalítica já é conhecida na literatura, teve seu protocolo de purificação otimizados pelo grupo, o que possibilitou a produção enzimática do ligante. A enzima YdeH de E.coli foi quantificada a $280 \mathrm{~nm}$ usando um coeficiente de extinção molar teórico de $\left(\varepsilon=40130 \mathrm{M}^{-1} \cdot \mathrm{cm}^{-1}\right)$. Após a obtenção da proteína (proveniente da primeira coluna de afinidade) iniciou-se a síntese. Para tanto, preparou-se o meio reacional para um volume final de $10 \mathrm{~mL}$, contendo tampão (Tris-HCl $50 \mathrm{mM}(\mathrm{pH} 7,5) / \mathrm{MgCl}_{2} 5 \mathrm{mM} /$ $\mathrm{NaCl} 50 \mathrm{mM}$ ), a enzima (YdeH) $2 \mu \mathrm{M}$ e GTP $500 \mu \mathrm{M}$, previamente diluído e quantificado em 
água. A reação, foi reservada sob suaves agitações, por aproximadamente $16 \mathrm{~h}$ (overnight). Dado esse tempo os tubos contendo as reações foram submetidos a banho quente $\left(\sim 98^{\circ} \mathrm{C}\right)$ por 5 min e em seguida centrifugados por $15 \mathrm{~min}$ a $2500 \mathrm{rpm}$. Assim, o sobrenadante foi filtrado utilizando o filtro de $0,25 \mu \mathrm{M}$, para extração dos precipitados proteicos. O produto do processo foi concentrado 10x, utilizando um concentrador à base de vácuo e centrifugação: Savant speedvac® PLUS SC210A (Thermo Quest).

A purificação do ligante foi procedida em um cromatógrafo AKTA (GE), utilizando a coluna de fase reversa VYDAC ${ }^{\mathrm{TM}}$ 218TP1010, com mistura de dois tampões para sua eluição: o acetato de amônio 100 mM (pH 6,0) (tampão A) e 70\% de metanol e 30\% do tampão A (tampão B). A injeção da amostra foi feita em volumes de $1 \mathrm{~mL}$. Pela característica apolar, o c-di-GMP se liga a resina e então é eluído com a aplicação de um gradiente de um tampão hidrofóbico constituído de $70 \%$ de metanol e 30\% do tampão A (formando o tampão B). O eluído foi seco completamente na Savant speedvac® PLUS SC210A (Thermo Quest). Por fim o ligante foi quantificado a $260 \mathrm{~nm}$, usando o coeficiente de extinção molar de $\left(\varepsilon=26100 \mathrm{M}^{-}\right.$ ${ }^{1}$. $\mathrm{cm}^{-1}$ ). (69) O rendimento gera em torno de $20 \%$ de conversão para o c-di-GMP, o que possibilitou os estudos biofísicos e cristalográficos com a proteína PelD ${ }^{\text {cito }}$.

\subsubsection{Caracterização biofísica das proteínas recombinantes $\operatorname{PelD}^{111-455}$ e PelD ${ }^{176-455}$ de Pseudomonas aeruginosa (PA14)}

Após a cromatografia de exclusão por tamanho, obtiveram-se proteínas com grau de pureza elevado, o que possibilitou os ensaios biofísicos da proteína com e sem o c-di-GMP, descritos abaixo.

\subsubsection{Estimativa da massa molecular aparente das proteínas PelD ${ }^{111-455}$ e PelD $^{176-455}$ nas formas apo e holo por cromatografia de exclusão por tamanho}

Para determinar os valorer das massas moleculares aparente das proteínas em seu estado oligomérico predominante em solução e, possivelmente confirmar seus valores 
teóricos, proteínas-padrão com diferentes massas moleculares, foram analisadas nas mesmas condições da cromatografia por exclusão molecular realizada com as duas construções recombinantes de PelD de P. aeruginosa na presença e na ausência do ligante c-di-GMP.

Os padrões utilizados foram: $3 \mathrm{mg} / \mathrm{mL}$ de aprotinina $(6500 \mathrm{Da}), 3 \mathrm{mg} / \mathrm{mL}$ de ribonuclease A (13700 Da), $3 \mathrm{mg} / \mathrm{mL}$ de anidrase carbônica $(29000 \mathrm{Da}), 3 \mathrm{mg} / \mathrm{mL}$ de ovalbumina ( $44000 \mathrm{Da})$ e 3mg/mL de conalbumina (75000 Da). O Blue Dextran 2000 (2000000 Da) a 1mg/mL foi utilizado como padrão para determinar o volume de exclusão da coluna (void). A partir do volume de eluição de cada padrão e das proteínas de estudo, foi possível obter curvas de calibração através do cálculo do coeficiente de partição (Kav), através da equação abaixo,

$$
K a v=\frac{V_{e}-V_{0}}{V_{c}-V_{0}}
$$

Sendo que, o $\mathrm{V}_{\mathrm{e}}$ corresponde ao volume de eluição, o $\mathrm{V}_{0}$ ao volume de exclusão da coluna e $\mathrm{V}_{\mathrm{c}}$ ao volume da coluna. Para tanto, foi utilizada uma coluna Superdex 75 10/300 (GE), previamente equilibrada com tampão (Tris-HCl $25 \mathrm{mM}(\mathrm{pH} \mathrm{8,0)/} \mathrm{NaCl} 500 \mathrm{mM}$ ), acoplada ao sistema de cromatografia AKTA explorer (GE). Foi aplicado $100 \mu \mathrm{L}$ de cada amostra de proteína (PelD ${ }^{111-455}$ e PelD ${ }^{176-455}$ ), nas formas apo e holo, com concentrações equivalentes, sendo que na forma holo em menor concentração pelo fato do pouco ligante (proporção 1: 10, proteína: ligante). O fluxo de corrida foi de $0,5 \mathrm{~mL} / \mathrm{min}$ e a corrida foi monitorada a $280 \mathrm{~nm}$. Os dados foram plotados em um gráfico para obtermos a equação da reta, utilizando o Software Origin 8.0.

\subsubsection{Medidas de ultracentrifugação analítica (AUC)}

A técnica AUC é uma ferramenta poderosa que permite estudar o comportamento de macromoléculas em solução em função do tempo, quando submetidas a um campo centrífugo uniforme. (70-71) Através desta técnica é possível determinar a massa molecular (MM) da macromolécula e obter informações sobre a heterogeneidade do sistema em relação à sua massa, ou seja, por quantas espécies o sistema é formado e qual a proporção entre elas. Assim 
como, ajuda na determinação de formas de agregados e se os mesmos são reversíveis ou irreversíveis em solução. (72-73)

Existem basicamente dois tipos de métodos utilizados na ultracentrifugação analítica: velocidade de sedimentação (SV) e sedimentação em equilíbrio (SE). O método de SV baseiase em propriedades termodinâmicas e usa alta velocidade de rotação para formar um gradiente de concentração de partículas em uma cela de amostra, que é medido por absorção de luz UV. Assim, à medida que a proteína sedimenta com o tempo, a migração da partícula em estudo é medida através da comparação com uma cela de referência, em que se encontra somente o solvente da amostra. (70-71) Deste modo, a partir das curvas de absorbância versus posição (raio) na cela, obtidos em diferentes instantes de tempo, é possível calcular uma distribuição de coeficiente de sedimentação, c(s), utilizando o programa SEDFIT (70). Já o experimento de SE, por sua vez, baseia-se em princípios termodinâmicos, sendo sensível à massa da partícula, e não ao seu formato. $\mathrm{O}$ experimento é feito em baixas velocidades de rotação, o suficiente para que as forças de sedimentação e difusão alcancem um equilíbrio. (70)

Neste trabalho foram realizados apenas experimentos de SV, sendo os mesmos realizados no Laboratório de Espectroscopia e Calorimetria (LEC) do Laboratório Nacional de Biociências (LNBio), Campinas-SP. As amostras usadas foram as duas construções citoplasmáticas de PelD ${ }^{111-455}$ e PelD ${ }^{176-455}$, variando as concentrações de proteína no tampão de purificação (Tris - $\mathrm{HCl} 25 \mathrm{mM}(\mathrm{pH}$ 8,0)/ $\mathrm{NaCl} 500 \mathrm{mM}$ ). O experimento foi realizado a uma velocidade de $40000 \mathrm{rpm}$, à $20{ }^{\circ} \mathrm{C}$, sendo monitorado à $280 \mathrm{~nm}$ em ultracentrífuga analítica Beckman Optima XL, equipada com rotor AN-50Ti com capacidade para oito celas (Beckman Coulter). Onde $420 \mu \mathrm{L}$ de solução de proteína foram adicionados na cela da amostra e $440 \mu \mathrm{L}$ de tampão foram adicionados na cela de referência.

Os dados contendo os múltiplos scans a $280 \mathrm{~nm}$ foram analisados a partir dos modelos: continuos $c(s)$ distribution e continuos $c(M)$ distribution, usando o programa SEDFIT (76) para determinar os coeficientes de sedimentação e os valores de massa molecular, respectivamente. Para análise dos dados houve a necessidade de obter alguns parâmetros de entrada usando o programa SEDNTERP (72-73) como: volume parcial específico de PelD ${ }^{111-455}$ e PelD ${ }^{176-455}$, densidade e viscosidade do solvente. 


\subsubsection{Medidas de calorimetria de titulação isotérmica (ITC)}

Calorimetria de titulação isotérmica (ITC) é uma técnica altamente poderosa e sensível que mede calores de interação de espécies reativas em solução, e tem sido utilizada com sucesso no estudo de interações entre biomoléculas (proteínas e ligantes, proteínas e lipídeos, proteínas e íons metálicos, proteína e proteína, proteína e DNA dentre outras), tanto do ponto de vista termodinâmico quanto cinético. (74-75)

Com o intuito de investigar as interações entre as diferentes construções da proteína PelD e o ligante c-di-GMP, foram realizadas medidas de calorimetria em um microcalorímetro de titulação isotérmica VP-ITC da MicroCal, no qual celas de reação com capacidade para $1,5 \mathrm{~mL}$ foram preenchidas com soluções de interesse e equilibradas a $25{ }^{\circ} \mathrm{C}$. Após atingir o equilíbrio, um período de atraso adicional foi deixado para gerar a linha de base utilizada nas análises de dados subsequentes. As soluções foram inicialmente desgaseificada por meio de um desgaseificador a vácuo (ThermoVac, MicroCal) durante 5 min, mantidas sob agitação constante.

Soluções contendo a proteína e o ligante foi preparado com o mesmo tampão (Tris$\mathrm{HCl} 25 \mathrm{mM}(\mathrm{pH}$ 8,0)/ NaCl $500 \mathrm{mM})$. O ligante c-di-GMP $(260 \mu \mathrm{M})$ foi titulado em uma cela contendo PelD $(20 \mu \mathrm{M})$ com uma injeção preliminar de $2 \mu \mathrm{L}$ seguido por 34 injeções de $8 \mu \mathrm{L}$ em intervalos de 4 min. O calor de diluição, medido através da injeção de c-di-GMP na mesma solução tampão de ensaio, foi subtraído de cada titulação para obter o valor de calor líquido de reação.

Os dados foram registrados e analisados utilizando Software Origin 7.0 (MicroCal). Estes calores foram utilizados para calcular a estequiometria da ligação $(\mathrm{N})$, a constante de associação $\left(\mathrm{K}_{\mathrm{a}}\right)$ e variação da entalpia molar $(\Delta \mathrm{H})$ da reação a partir da curva de titulação. Como os valores de $K_{a}$ são muito grandes, mencionaremos sempre os valores de $K_{d}$, que é inversamente proporcional à $\mathrm{K}_{\mathrm{a}}$. 


\subsubsection{Medidas de dicroísmo circular (CD)}

Esta técnica consiste em irradiar uma amostra de interesse com um feixe de luz polarizada circularmente à direita e à esquerda. Mede-se a diferença de absorção da radiação polarizada circular à esquerda $L_{r}$ e à direita $R_{r}$. (77) $O$ sinal é dado em termos da diferença $(\theta$ $\left.=L_{r}-R_{r}\right)$ em função do comprimento de onda. É obtido também, a elipticidade $(\theta)$ em mdeg.dmol ${ }^{-1} \cdot \mathrm{cm}^{2}$, que é o grau de rotação do campo elétrico da radiação no plano polarizado pelas moléculas. Essa diferença de absorção à direita e à esquerda e a distorção do plano de polarização da luz é sensível a mudanças na estrutura da biomolécula. (78)

Os espectros de CD foram obtidos utilizando um espectropolarímetro modelo J-810 equipado com banho de água TC-100 e controlador de temperatura peltier PFD 425S (JASCO). As amostras de ambas as proteínas foram incubadas em tampão fosfato de sódio 20 $\mathrm{mM}$ (pH 7,0)/ $\mathrm{NaCl} 100 \mathrm{mM}$, com uma concentração de 0,2 mg/mL. As medidas foram feitas tanto na sua forma apo, como complexada com c-di-GMP em proporção de 1:2. Dessa forma, foram coletadas em cubetas com caminho óptico de 1,0 $\mathrm{mm}$ e os parâmetros utilizados foram: leitura de $197-250 \mathrm{~nm}$, temperatura de $20^{\circ} \mathrm{C}$, coleta de dados de $0,5^{\circ} \mathrm{C}$, velocidade de $50 \mathrm{~nm} /$ min, resolução de $0,5 \mathrm{~nm}$, resposta de $2 \mathrm{~s}$ e comprimento de onda $1 \mathrm{~nm}$.

Os resultados obtidos no CD foram corrigidos e ajustados para a contribuição do tampão, e a elipsidade convertida para elipsidade residual molar através da equação 3 :

$$
[\theta]=\frac{m \operatorname{deg} \cdot P M}{L \cdot N R \cdot[] \cdot 10}
$$

Onde, $[\theta]$ : elipsidade molar; PM: peso molecular em Daltons; L: caminho óptico da cubeta; NR: número de resíduos de aminoácidos; [ ]: concentração da proteína em mg/mL.

As predições do conteúdo de estruturas secundárias foram realizadas utilizando o programa CDpro (79), que consiste em um pacote de softwares que analisam os espectros de CD de uma dada proteína para determinar as porcentagens de estruturas secundárias através dos programas SELCON3, CDSSTR e CONTIN. (79-80) 


\subsubsection{Cristalização}

Cristalização é um processo de ordenação, no qual as moléculas assumem posições regulares no estado sólido. Um processo que pode ser considerado como um equilíbrio dinâmico entre partículas no estado líquido e no estado sólido. Sendo assim, o cristal cresce quando o equilíbrio é deslocado no sentido de solidificação. (81-82)

O principal objetivo da cristalização de uma macromolécula biológica, tais como proteínas, ácidos nucléicos ou vírus, é o seu estudo estrutural por métodos de difração de raios $\mathrm{X}$. Este estudo é fundamental para o entendimento molecular de vários mecanismos biológicos e se mostra uma das etapas mais críticas na resolução da estrutura de uma macromolécula biológica. (82) Esta técnica constitui-se de múltiplos parâmetros que envolvem os três passos clássicos: nucleação, crescimento e término de crescimento. Existem vários métodos para cristalização de macromoléculas biológicas, dentre eles: diálise, difusão em interface livre, batch e difusão de vapor. (83-85) O método utilizado neste trabalho foi o de difusão de vapor, que consiste no processo de equilíbrio entre duas soluções através da fase de vapor no meio fechado (figura 9). A solução menos concentrada poderá perder seu solvente volátil até que potenciais químicos das duas soluções sejam iguais. (83)

A elucidação da estrutura tridimensional de proteínas pelo método cristalográfico está condicionada à obtenção de cristais de tamanho e qualidade que possibilitem a coleta de dados de difração de raios-X. (82-84)

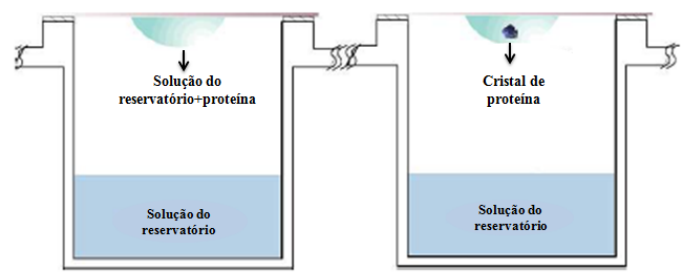

Figura 9 - Representação esquemática do experimento de cristalização por difusão de vapor em gotas suspensas. A gota contendo a proteína em solução apresenta igual composição do reservatório do poço, porém, com metade da concentração, o que leva a perda do solvente lentamente, até que as concentrações da gota e do poço adquiram uma condição de equilíbrio. Adaptado. (82) 
Ensaios iniciais de cristalização foram realizados utilizando o método de difusão de vapor em placas de cristalização, em "gota sentada" utilizando o sistema robotizado do Laboratório de Cristalografia do Instituto de Física de São Carlos - USP, e também manualmente. Utilizou-se kits contendo 96 condições, disponíveis comercialmente pelas empresas Hampton Research e Quiagem, como: Wizard Screens I e II, SaltRX, Crystal Screen I e II, Index HT, Classic Suite, PEG's Suite dentre outros.

O reservatório das placas utilizadas pelo sistema robotizado armazena $80 \mu \mathrm{L}$ de solução precipitante. A gota foi preparada com uma relação de 1:1 (1 $\mu \mathrm{L}$ de proteína e $1 \mu \mathrm{L}$ de precipitante). A proteína foi utilizada em várias concentrações finais: $5 \mathrm{mg} / \mathrm{mL}, 10 \mathrm{mg} / \mathrm{mL}$, $16 \mathrm{mg} / \mathrm{mL}, 36 \mathrm{mg} / \mathrm{mL}$ no mesmo tampão de purificação (Tris- $\mathrm{HCl} 25 \mathrm{mM}(\mathrm{pH} 8,0) / \mathrm{NaCl}$ $500 \mathrm{mM}$ ). Também foram preparadas placas de 96 poços, manualmente, utilizando os mesmos kits comerciais, onde foram colocados $70 \mu \mathrm{L}$ de solução precipitante, com uma relação também de 1:1.

Após a preparação das gotas, as placas foram vedadas e acondicionadas em uma sala com temperatura controlada. Foram testadas duas temperaturas de cristalização $\left(4^{\circ} \mathrm{C}\right.$ e $\left.18^{\circ} \mathrm{C}\right)$. O monitoramento do crescimento de cristais foi realizado por meio da observação das gotas com auxílio de uma lupa de aumento. Obtendo sucesso com o crescimento de cristais de proteína em apenas duas condições. Encontrada as condições de cristalização partiu-se para a otimização das condições iniciais, variando o pH e a concentração de PEG, desta vez usando uma placa com 24 poços com capacidade para $1 \mathrm{~mL}$,através do método de difusão de vapor em "gota suspensa"(figura 9). Em geral, neste método uma alíquota de $2 \mu \mathrm{L}$ da solução de proteína a $1-5 \mathrm{mg} / \mathrm{mL}$ foi misturada sobre uma lamínula siliconizada com um mesmo volume da solução precipitante. Em seguida esta lamínula foi vedada com uma graxa de silicone, servindo de tampa para o poço. Uma vez que o sistema encontra-se vedado, as duas soluções entram em equilíbrio pela transferência de água da gota suspensa para a solução no poço (figura 9). A perda d'água e o consequente aumento da concentração de proteína e precipitante na gota induz a cristalização ou a formação de precipitado.

Uma vez que foi obtido cristais apenas para a proteína PelD ${ }^{176-455}$ os mesmos foram submetidos ao método de soaking (82) para a incorporação de átomos pesados. Neste método, o cristal é embebido por cerca de alguns minutos em uma solução idêntica à solução de cristalização com adição de variadas concentrações de átomos pesados. O sal usado foi o 
iodeto de sódio (NaI 0,1-0,5M). Da mesma forma, fez-se com o ligante, onde outros cristais foram deixados imersos em soluções contendo c-di-GMP (2 mM) por 16h e submetidos posteriormente à difração.

\subsubsection{Resolução estrutural por difração de raios-X}

Foram coletados dois excelentes conjuntos de dados, um derivado de NaI (PelD ${ }^{176-}$ ${ }^{455}+$ iodo) e outro em complexo com c-di-GMP (PelD $\left.{ }^{176-455}+\mathrm{c}-\mathrm{di}-\mathrm{GMP}\right)$, usando fontes de raio$\mathrm{X}$ provenientes de um ânodo rotatório coletados no laboratório de cristalografia do Instituto de Física de São Carlos - USP, equipado com detector de imagens do tipo R-axis IV $^{++}$ (Rigaku).

Para a proteção dos cristais contra o congelamento, antes da irradiação, os mesmos foram embebidos em uma solução idêntica à solução do poço acrescida de $25 \%$ (V/v) de etileno glicol (1, 2 etanodiol), álcool de fórmula $\mathrm{HO}-\mathrm{CH}_{2} \mathrm{CH}_{2}-\mathrm{OH}$. Durante o processo de irradiação os cristais foram mantidos em fluxo de nitrogênio para minimizar os danos da radiação ao cristal. As imagens de difração foram processadas em softwares específicos, com o auxílio do pacote de programas XDS. (85)

O problema das fases foi resolvido pelo método de $S A D$. (86) A posição dos átomos de iodo foi determinada por métodos diretos com ajuda do programa SHELXD. (87) O sinal anômalo do derivado de iodo possibilitou a determinação das posições dos átomos pesados no cristal. Essas posições foram usadas pelo programa PHENIX (88) para o cálculo das fases. Usando os programas PHENIX (88) e COOT (89) para um refinamento interativo foi possível visualizar o mapa de densidade eletrônica e construir um modelo das estruturas.

Após o refinamento, os modelos foram validados utilizando-se os métodos: avaliação do valor de $\mathrm{R}_{\mathrm{work}}$ e $\mathrm{R}_{\text {free}}$; validação pelos programas MolProbity (90) e ProCheck (91). Depois de validadas, as estruturas foram submetidas à análise estrutural e funcional, em comparação a outras estruturas, com domínios semelhantes depositadas no PDB. 


\section{Papitulo 4}

\section{Qesultados e Discussã̃o}

Neste capítulo serão apresentados os resultados obtidos desde a clonagem dos genes das proteínas recombinantes, até os estudos biofísicos e estruturais da proteína PelD. Elucidando seu importante papel na via de sinalização responsável pela formação de exopolissacarídeos em Pseudomonas aeruginosa (PA14) através da proposta do seu mecanismo de ativação por c-diGMP. 


\subsection{RESULTADOS E DISCUSSÃO}

\subsubsection{Análise da sequência de aminoácidos e delimitação da construção solúvel de PelD utilizando as ferramentas de bioinformática}

A proteína PelD de $P$. aeruginosa (PA14) possui um total de 455 resíduos de aminoácidos e massa molecular teórica de $51,07 \mathrm{kDa}$, com ponto isoelétrico teórico igual a 5,52, conforme calculado pela ferramenta ExPASy. (58) Como a PelD é uma proteína de membrana, contendo domínios citosólicos $(29,58)$, optou-se por estudar inicialmente sua parte solúvel, dadas as dificuldades técnicas de se trabalhar com proteínas de membrana. Portanto, as construções clonadas foram delimitadas a partir de uma análise dos domínios conservados, da previsão dos elementos de estruturas secundárias e de hélices transmembranares presentes em PelD.

A análise de domínios da sequência de PelD de P. aeruginosa (PA14) através do servidor Pfam (92) e Phyre Server (61) revelou três domínios bem conservados: um domínio com função desconhecida, o DUF4118, localizado entre os resíduos 18-117, com E-value de 6,2e-26, o domínio GAF, conhecido por realizar interação proteica e ligar pequenas moléculas, localizado entre os resíduos 180-309, com E-value de 6,3e-13 e o domínio GGDEF, caracterizado como domínio ativo em diguanilato ciclases que sintetizam c-di-GMP, localizado entre os resíduos 320-455. (figura 10).

N-terminal

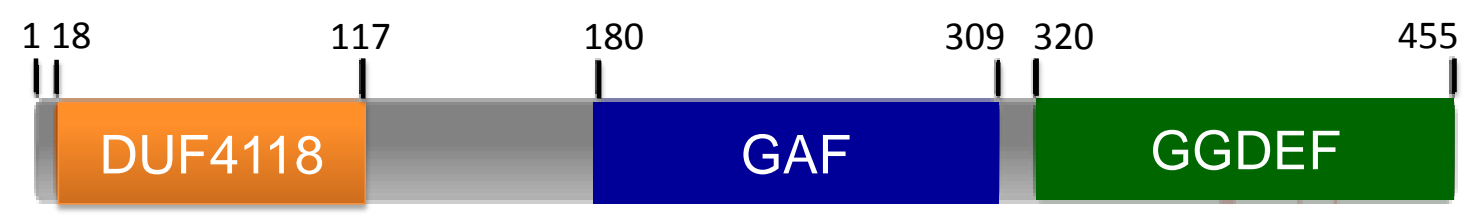

Figura 10 - Desenho esquemático dos domínios conservados presentes na proteína PelD. A predição foi realizada através dos programas Pfam (96) e Phyre Server (67). Em laranja DUF4118 (18-117), em azul o GAF (180-309) e em verde o GGDEF (320-455). 
Como esperado, uma predição das hélices transmembranares de PelD com o programa HMMTOP (59) identificou quatro hélices hidrofóbicas no N-terminal da proteína, compreendendo os resíduos 1-110 (figura 11). Essa região coincide com o domínio de função desconhecida DUF4118, o qual aparece recorrentemente em proteínas de sinalização bacteriana. Além das proteínas homólogas a PelD, uma análise de arquiteturas proteicas contendo esse domínio (DUF4118) mostra sua presença em outros domínios de sinalização, tais como: PAS, reguladores de resposta e principalmente histidina-quinases.

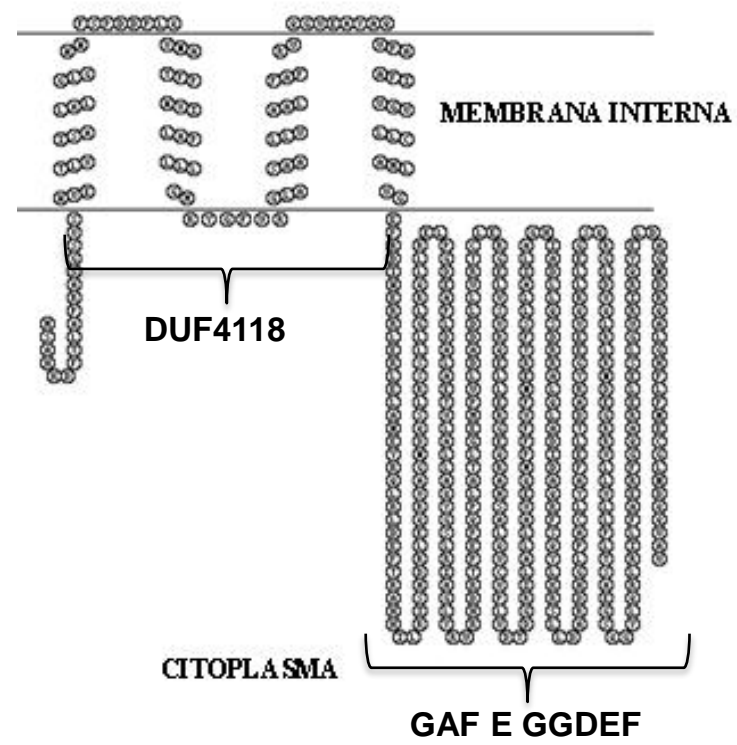

Figura 11 - Predição de hélices transmembranas e topologia da proteína PelD realizada através do programa HMMTOP versão 2.0. (59) A figura mostra que a proteína PelD possue 4 hélices transmembranas (membrana interna), que compreende o domínio DUF4118, onde a primeira está localizada entre os resíduos 19-35, a segunda entre o 44-60, a terceira entre 67-83 e a quarta entre $92-108$. Sendo que, a partir do resíduo 111 inicia sua porção citoplasmática, que compreende os domínios GAF e GGDEF.

Uma outra análise de bioinformática bastante importante feita com PelD, foi a análise de predição de coiled-coil (figura 12) que analisa a possibilidade de uma determinada região da proteína ter a capacidade de formar coiled-coil a partir de sua sequência primária. Essa estrutura, compreende de hélices espiraladas e está intimamente envolvida com a dimerização da proteína, o que pode consequentemente está relacionada com sua função proteica. De acordo com as predições feitas através do programa Marcoil (62), PelD apresenta duas regiões envolvidas na formação de coiled-coil, as quais estão localizadas entre o domínio transmembranar DUF4118 e o início do domínio citoplasmático GAF, como pode ser observado na figura 12. O que pode está relacionado ao seu estado oligomérico e consequente 
função proteica, uma vez que a formação de coiled-coil é caracterizada pela formação de oligômeros, podendo assim indicar que PelD pode ser dimérica in vivo.

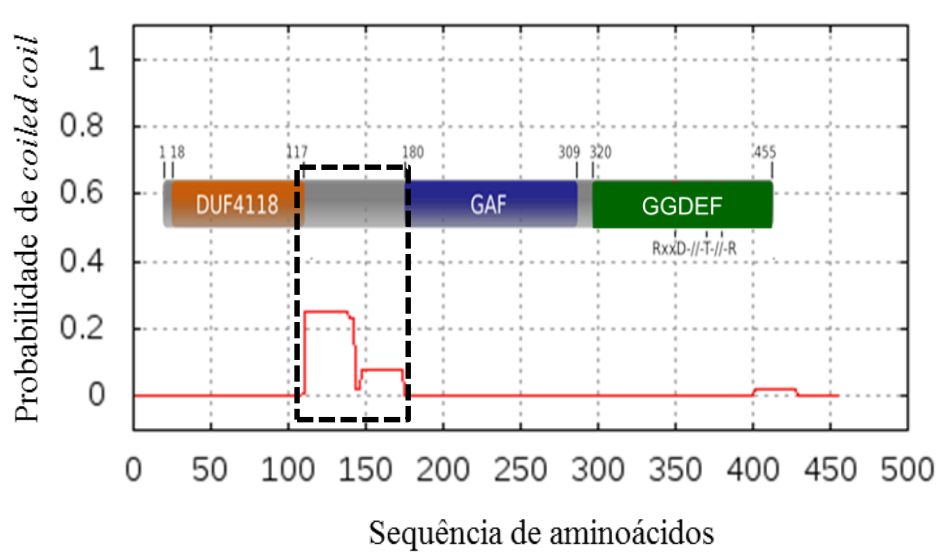

Figura 12 - Predição de coiled-coil da proteína PelD, realizada através do programa MARCOIL. (62) A figura mostra que a proteína PelD possui duas regiões com probabilidade de formar coiled-coil, ambas estão entre o domínio transmembranar DUF4118 e o domínio citoplasmático GAF.

Adicionalmente, resultados de predição de estruturas secundárias apresentados pelo programa PSIPRED (60) indicaram uma grande hélice a partir da $\mathrm{Ala}^{94}$ até Ala ${ }^{154}$ (figura 13). De acordo com alguns estudos o ideal é que o truncamento de uma proteína para se excluir alguma parte deve ser feito em regiões previstas como loops, para evitar possíveis instabilidades na proteína expressa. No entanto, essa grande hélice que conecta o domínio transmembranar DUF4118 com o domínio GAF na parte solúvel da proteína, está potencialmente envolvida na dimerização da parte citoplasmática de PelD uma vez que estudos prévios demonstraram que ela possui características para formar um "coiled-coil". (29-30)

Dessa forma, decidiu-se "truncar" inicialmente a proteína a partir do resíduo 111, gerando primers para clonagem inicial do fragmento 111-455, o qual deveria gerar uma proteína contendo toda a parte solúvel citoplasmática de PelD. Sendo assim, primers foram desenhados para clonagem dos domínios GAF e GGDEF isolados, bem como construções contendo os domínios GAF-GGDEF separadamente. 


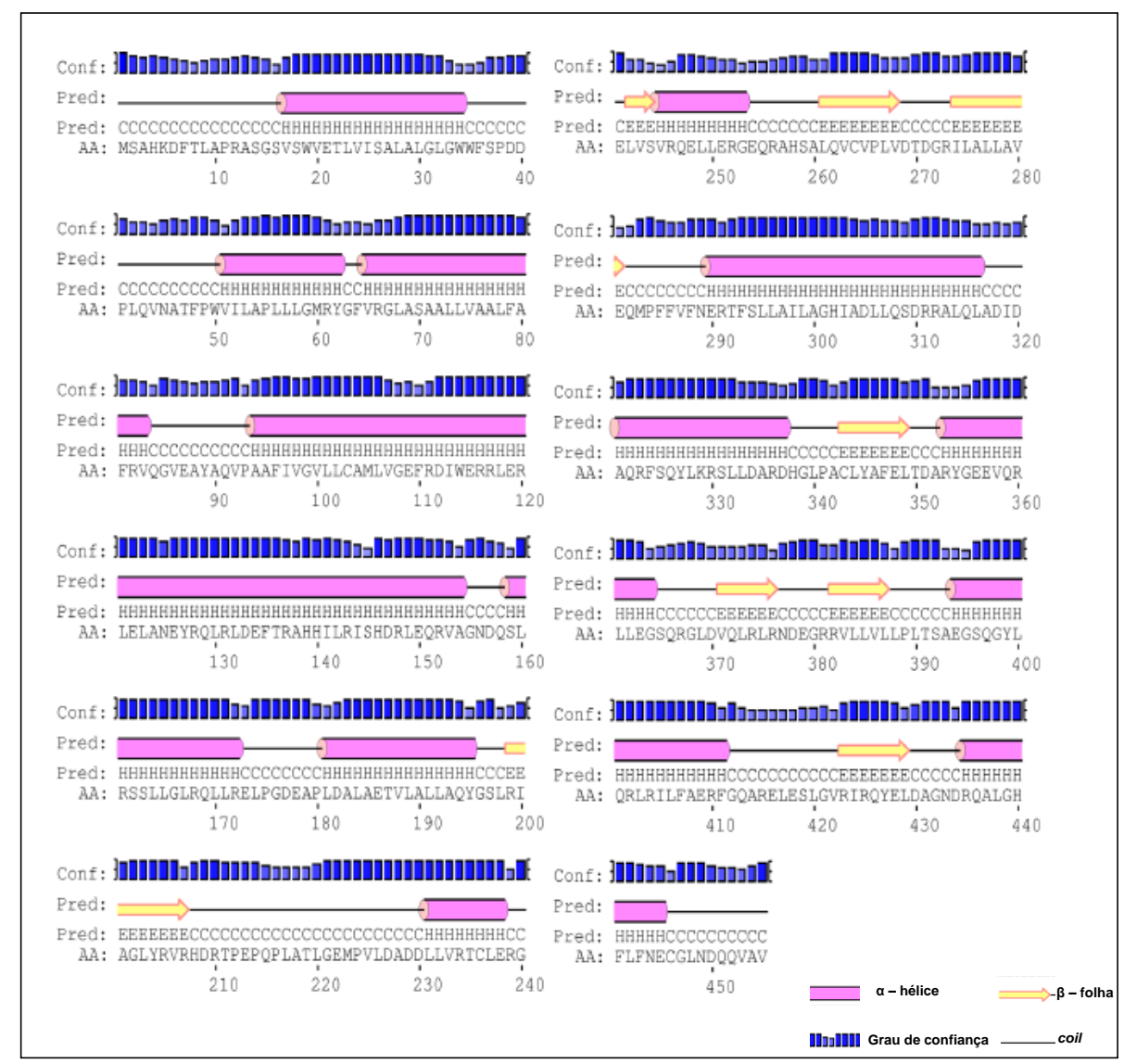

Figura 13 - Predição de estruturas secundárias de PelD a partir da sequência primária, usando o programa PSIPRED. (60) As hélices- $\alpha$ estão indicadas em rosa e as folhas- $\beta$ em amarelo. Acima do diagrama de estruturas secundárias encontra-se uma escala com a confiabilidade da predição e abaixo o código de letras para hélices $\alpha(\mathrm{H})$, folhas $\beta(\mathrm{E})$ e loops $(\mathrm{C})$, bem como a sequência primária de PelD.

Tendo como base todas as predições de bioinformática citadas acima, foram desenhadas várias construções redundantes da proteína PelD, que diferem apenas pela presença de alguns resíduos nos pontos de truncagem. Essa estratégia foi adotada visando um aumento na probabilidade de se conseguir uma construção cristalizável de PelD. O total de 11 construções previstas e os respectivos primers encontram-se na tabela 3. 


\subsubsection{Amplificação e clonagem das construções de PelD em vetor de expressão pET- SUMO}

As construções solúveis de PelD foram amplificadas utilizando-se os primers descritos na tabela 3, a partir do DNA genômico de P. aeruginosa PA14. Visando a clonagem direta no vetor de expressão pET-SUMO, todos os primers incluíam quatro bases na posição 5', antes dos sítios das endonucleases. A inclusão dessas bases garante a máxima eficiência das enzimas de restrição na clivagem dos produtos de PCR amplificados. Após a ligação das construções amplificadas no vetor pET-SUMO, bactérias competentes E. coli DH5 $\alpha$ foram transformadas com as misturas de ligação para seleção dos plasmídeos recombinantes.

Para cada transformação, algumas colônias foram selecionadas, os plasmídeos foram recuperados e digeridos com enzimas de restrição adequadas, para confirmação da presença do inserto. Pôde-se constatar através das bandas no gel de agarose que os tamanhos são compatíveis com o esperado e que, portanto a clonagem funcionou para todas as construções, com exceção de um dos domínios GAF amplificados (PelD ${ }^{176-314}$ ) (figura 14). Com a confirmação adicional da presença do inserto nas colônias selecionadas, realizou-se uma análise através da técnica de sequenciamento e somente após a confirmação da ausência de mutações partiu-se para os testes de indução, solubilidade e expressão e purificação.

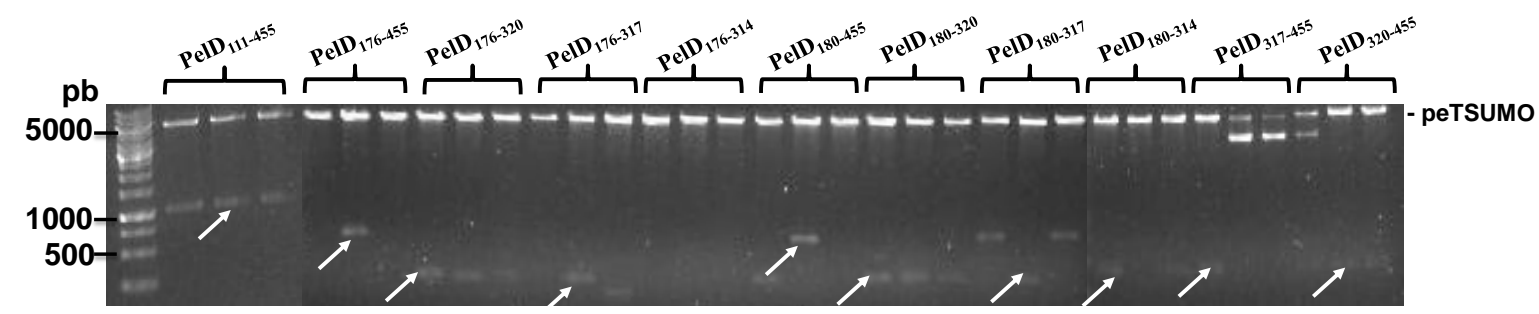

Figura 14 - Eletroforese em gel de agarose 1\%, TAE (1x) mostrando os produtos de digestão de três clones diferentes de cada uma das 11 construções solúveis da proteína recombinante PelD. As bandas em destaque relativas ao vetor pET-SUMO aparecem em torno de 5000pb e os insertos, com diferentes tamanhos, estão apontados com uma seta branca.

Como será apresentado nas seções seguintes, os trabalhos de cristalização, determinação de estado oligomérico e afinidade por c-di-GMP, análises de estrutura 
secundária foram realizadas somente com duas construções (PelD ${ }^{176-455}$ e PelD ${ }^{111-455}$ ). Dessa forma, não foi dispendido maiores esforços para clonagem da construção PelD ${ }^{176-314}$.

\subsubsection{Expressão e purificação}

Para determinação de protocolos de expressão e purificação, todas as construções de PelD clonadas com sucesso foram transformadas em bactérias BL21 (DE3). As colônias isoladas, relativas a cada um dos clones, foram cultivadas em diferentes condições de temperatura e concentração de IPTG, visando à otimização da produção de proteína na sua forma solúvel. Observou-se que a $37^{\circ} \mathrm{C}$, independentemente da concentração de IPTG, a maior parte das construções encontravam-se na fração insolúvel (gel não mostrado) após indução por 3 horas. Por outro lado, com a expressão a $18^{\circ} \mathrm{C}$ por 16 horas, foi possível a obtenção de quantidade satisfatória das proteínas recombinantes solúveis, sendo que a concentração de 0,01 mM de IPTG já era suficiente para observar indução da expressão. Dessa forma, estabeleceu-se a condição de expressão a $18^{\circ} \mathrm{C}$ por 16 horas, utilizando a concentração de 0,5 mM de IPTG, para garantir a indução de grande quantidade de proteína. A figura 15 mostra um exemplo da análise em SDS-PAGE da avaliação das condições de expressão para a construção PelD ${ }^{111-455}$.

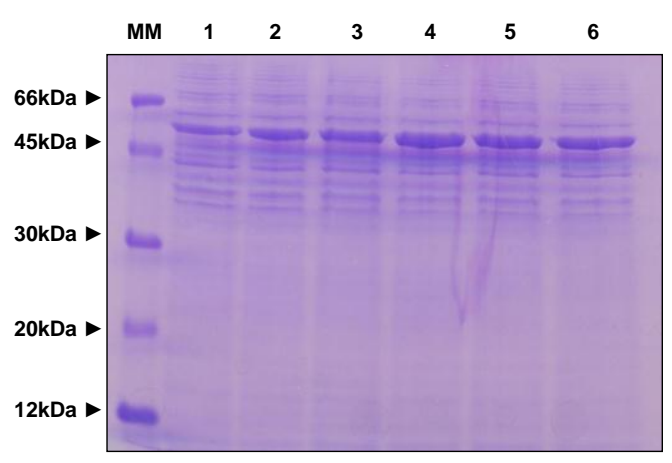

Figura 15 - Análise em SDS-PAGE $15 \%$ dos testes de indução a $18^{\circ} \mathrm{C}$ em E. coli BL21(DE3) para PelD ${ }^{111-455}$. (MM) Marcador de massa molecular; (1) Fração solúvel não induzida; (2-6) Frações solúveis com concentrações crescentes de IPTG $(0,01 \mathrm{mM}, 0,1 \mathrm{mM}, 0,3 \mathrm{mM}, 0,5 \mathrm{mM}$ e $1 \mathrm{mM})$.

Como já mencionado, a estratégia de se trabalhar com múltiplas construções visava especialmente um aumento na probabilidade da obtenção de cristais adequados para determinação estrutural de PelD. Sendo assim, purificações paralelas foram conduzidas em 
uma pequena escala, produzindo proteína suficiente para um "screen” inicial de cristalização apenas com o Kit Index HT (Hampton Research). Nesses experimentos foi possível observar cristais somente para a construção PelD ${ }^{176-455}$, que engloba os dois domínios citoplasmáticos conservados em PelD (GAF e GGDEF degenerado). Sendo assim tornou-se desnecessário a continuação dos trabalhos com as construções dos domínios isolados de PelD (tais como PelD ${ }^{176-320}$, GAF, e PelD ${ }^{320-455}$, GGDEF, por exemplo), uma vez que de um ponto de vista funcional e estrutural a construção PelD ${ }^{176-455}$ contém mais informação. Interessante também destacar que uma construção PelD ${ }^{180-455}$, apesar de possuir apenas 4 resíduos a menos que PelD ${ }^{176-455}$, não cristalizou nos ensaios iniciais, indicando que de fato uma pequena mudança estrutural pode ter grande impacto na cristalizabilidade da proteína recombinante.

Além da construção PelD ${ }^{176-455}$, também foram desenvolvidos trabalhos com a construção PelD ${ }^{111-455}$, a qual engloba toda a porção solúvel citoplamática de PelD, incluindo a hélice juxtamembrana essencial para dimerização de PelD citoplasmática. Dessa forma, desse ponto em diante todos os resultados apresentados serão em referência a essas duas construções.

As purificações de PelD ${ }^{111-455}$ e PelD ${ }^{176-455}$ foram estabelecidas com o mesmo protocolo e seguiram várias etapas: cromatografia de afinidade por íons metálicos imobilizados (IMAC) (64), clivagem da 6xHis-SUMO com a protease 6xHis-Ulp1, troca de tampão para remoção do imidazol, re-cromatografia (IMAC) para eliminação do 6xHisSUMO e 6xHis-Ulp1 e cromatografia por exclusão molecular em coluna Superdex 75 10/300 (GE).

Para produção em larga escala, as células provenientes de $2 \mathrm{~L}$ de cultura foram centrifugadas, ressuspensas em tampão de lise e sonicadas. Uma nova centrifugação removeu os detritos celulares e bactérias não lisadas do sobrenadante, que continha as construções de PelD recombinantes. O lisado foi então incubado com a resina Talon (íons $\mathrm{Co}^{2+}$ imobilizados) e lavado com tampão de lise para remoção de contaminantes que não interagem com a resina. A eluição das construções de PelD foi realizada com a aplicação de um gradiente crescente de imidazol no tampão (10 mM- $500 \mathrm{mM})$. Amostras do pellet, sobrenadante, lavagens e eluição da proteína com gradiente de imidazol foram visualizadas em gel de poliacrilamida $15 \%$ corado com coomassie blue (figura 16). 

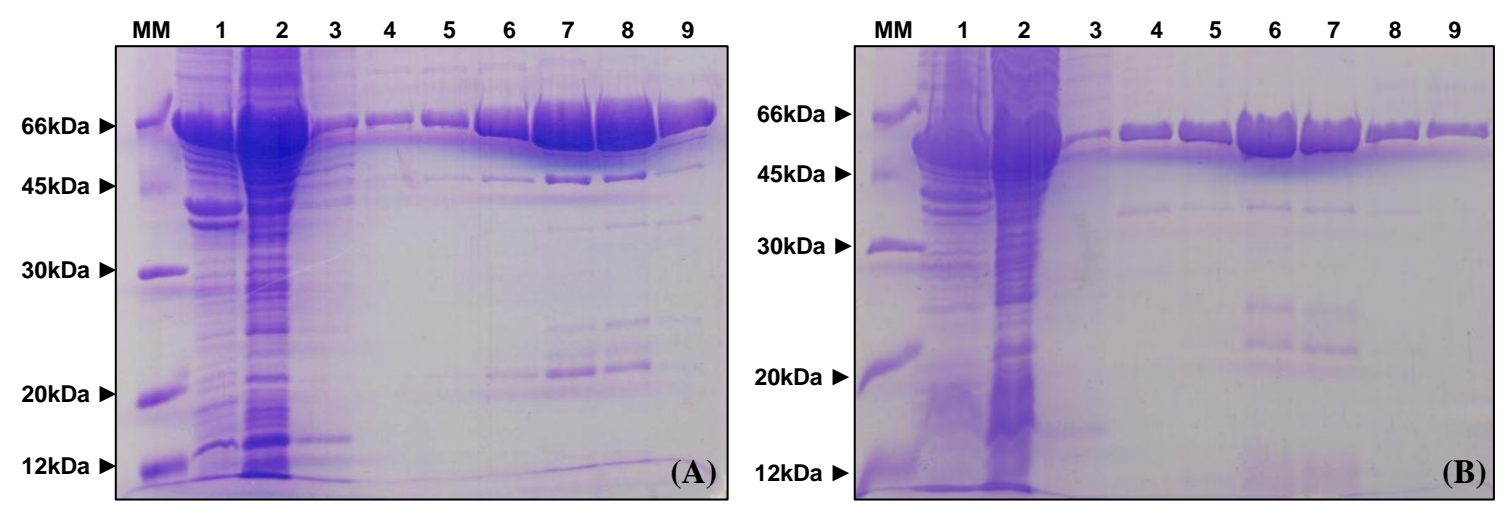

Figura 16 - Análise eletroforética da primeira etapa de purificação das construções de PelD recombinantes em resina Talon. (A) SDS-PAGE 15\% para construção PelD ${ }^{111-455}$ e (B) para construção PelD ${ }^{176-455}$, onde cada canaleta representa as frações: (MM) marcador de massa molecular; (1) pellet; (2) sobrenadante; (3) lavagem; (4-9) eluição com imidazol (10, 20, 50, 100, 250 e $500 \mathrm{mM}$ )

As frações com maior teor de pureza foram submetidas a uma cromatografia em coluna HiPrep 10/16 dessalting (GE) para a retirada do imidazol. Feito isso, as amostras de ambas as proteínas foram submetidas à clivagem com a protease $6 x H i s-U l p 1(1 \mathrm{mg} / \mathrm{mL}$ de protease para $30 \mathrm{mg} / \mathrm{mL}$ de proteína de fusão) por $1 \mathrm{~h}$ a temperatura ambiente $\left(\sim 25^{\circ} \mathrm{C}\right)$. Essa etapa de clivagem da 6xHis-SUMO da proteína de fusão foi otimizado após vários testes variando-se tempo de incubação (1h, $2 \mathrm{~h}, 3$ e overnight), temperatura $\left(\sim 25^{\circ} \mathrm{C}\right.$ e $\left.18^{\circ} \mathrm{C}\right)$ e razão de massa de protease:proteína de fusão (1:10, 1:20 e 1:30) (dados não mostrados).
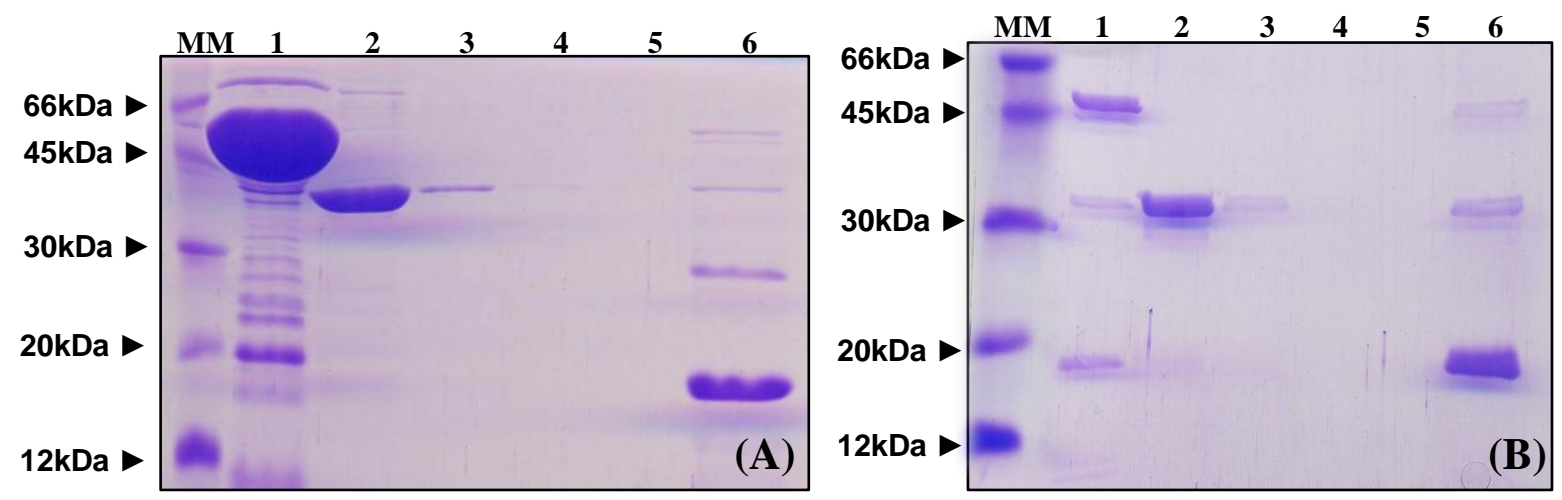

Figura 17 - Análise eletroforética da clivagem e segunda IMAC das construções de PelD recombinantes. (A) SDS-PAGE $15 \%$ para construção PelD ${ }^{111-455}$ e (B) para PelD ${ }^{176-455}$. (MM) marcador de massa molecular; (1) $1^{\mathrm{a}}$ IMAC, antes da clivagem com Ulp1; (2) Fração que não interage com a Talon ( $2^{\mathrm{a}}$ IMAC), após clivagem. As bandas de PelD ${ }^{111-455}$ e PelD $^{176-455}$ aparecem com a massas esperadas em torno de $39 \mathrm{kDa}$ e $30 \mathrm{kDa}$, respectivamente; (3-4) lavagem da coluna com tampão sem imidazol $\left(2^{\mathrm{a}}\right.$ IMAC); (6) eluição da SUMO-tag ( 13 kDa) protease Ulp1 ( 30 kDa) com $500 \mathrm{mM}$ Imidazol $\left(2^{\mathrm{a}}\right.$ IMAC).

Uma nova cromatografia em resina talon foi realizada para separar a 6xHis-SUMO clivada e 6xHis-Ulp1 das construções de PelD (figura 17). Pela figura acima ficou evidente 
que o protocolo otimizado possibilitou a obtenção de proteína pura para ambas as construções de PelD (figura 17, canaleta 2).

Apesar das etapas anteriores de purificação terem permitido a obtenção de proteínas com alto grau de pureza, ensaios de cristalização demandam amostras homogêneas, ou seja, sem agregados não específicos. Dessa forma, uma etapa adicional de cromatografia de exclusão molecular em coluna Superdex 75 10/300 (GE) foi realizada para separação de eventuais agregados proteicos das construções de PelD.

São notáveis dois picos bem definidos nos perfis cromatográficos de ambas construções. Como esperado, o primeiro correspondente a agregados proteicos, já que sua eluição se deu no void ( 8 mL) da coluna Superdex 75 10/300 (GE). O segundo pico de cada purificação aparece bem definido em $\sim 11,00 \mathrm{~mL}$ e $\sim 12,00 \mathrm{~mL}$, correspondente às frações no estado monomérico em solução de PelD ${ }^{111-455-}$ e PelD ${ }^{176-455}$, respectivamente (figura 18).
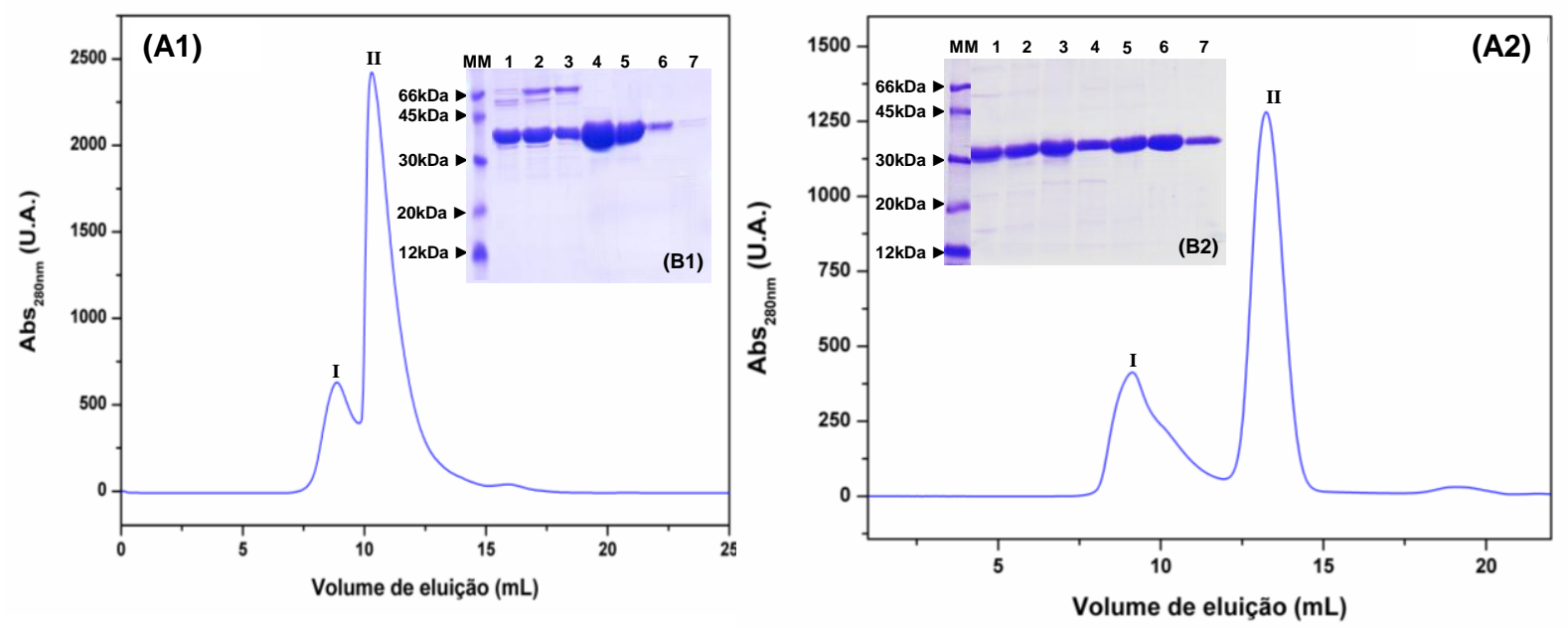

Figura 18 - Perfil de eluição em coluna Superdex 75 10/30 (GE) e análise eletroforética da última etapa de purificação das proteínas recombinantes. (A1) Cromatograma da PelD ${ }^{111-455}$ e (A2) da PelD ${ }^{176-455}$; em destaque SDS-PAGE 15\% mostrando frações da gel filtração, (B1) (1-3) correspondem ao pico I e (4-7) ao pico II; (B2) (1-3) correspondem ao pico I e (4-7) ao pico II.

O procedimento otimizado de expressão e purificação permitiu a obtenção de grande quantidade de proteína com grau de pureza e homogeneidade elevada, o que possibilitou os ensaios biofísicos e estruturais. Foram purificados aproximadamente $10 \mathrm{mg}$ da construção PelD ${ }^{111-455}$ e 5 mg da construção PelD ${ }^{176-455}$ por litro de cultura. 


\subsubsection{Cristalização, coleta e processamento dos dados de difração de PelD ${ }^{176-455}$}

Como foi dito anteriormente não obtivemos sucesso na cristalização da construção PelD ${ }^{111-455}$. Isto se deve principalmente ao fato desta construção apresentar parte de uma grande hélice transmembranar envolvida na formação de coiled-coil, predito por bioinformática. Assim, os resultados apresentados nesta seção referem-se apenas a construção PelD ${ }^{176-455}$.

Com o objetivo de se obter informações experimentais de alta resolução acerca da estrutura tridimensional de PelD ${ }^{176-455}$, com e sem o ligante c-di-GMP, foram realizadas inúmeras triagens de condições de cristalização, como descrito na seção 3.1.15. Observaramse microcristais em duas condições do kit Index HT (Hampton Research): Sulfato de amônio 0,2 M, Bis-Tris 0,1M pH 6,5, 25\% Polietileno glicol 3,350 e Sulfato de lítio monohidratado 0,2M, Bis-tris 0,1M pH 6,5, 25\% Polietileno glicol 3,350. Tendo encontrado condições iniciais partiu-se então para um refinamento visando à reprodução e obtenção de cristais adequados para coleta de dados de difração de raios X. Nos experimentos de otimização, os cristais cresceram em forma de placas finas em aproximadamente dois dias e em uma semana atingiram sua maior dimensão (figura 19).
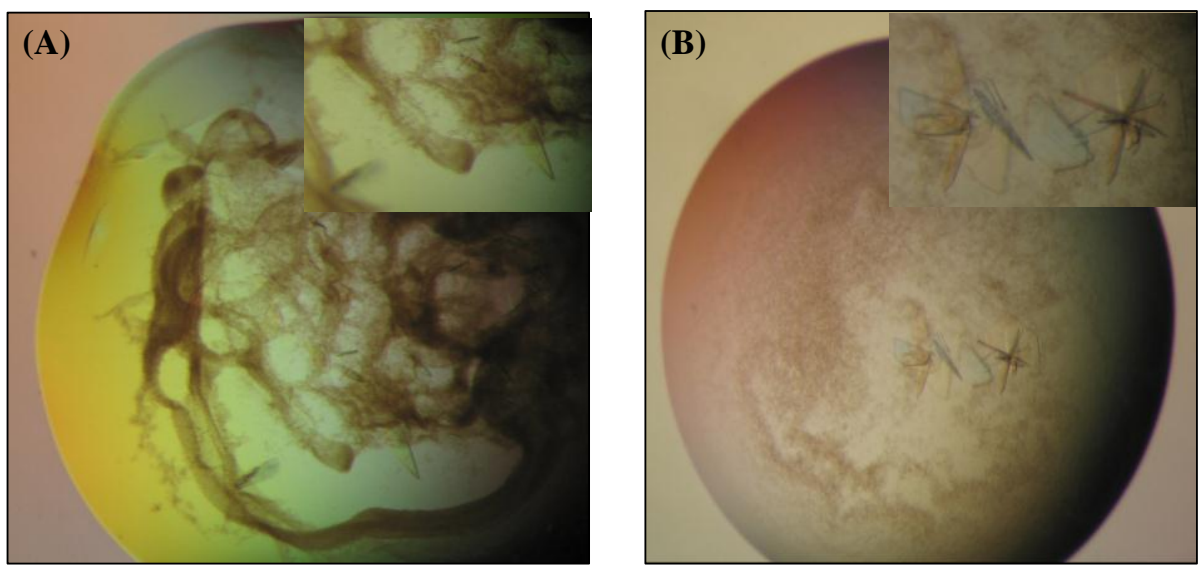

Figura 19 - Cristais de PelD ${ }^{176-455}$ obtidos após a otimização das condições iniciais. (A) Cristais crescidos na condição Bis-tris 0,1 M (pH 6,5), Sulfato de amônia 0,2 M, PEG $335025 \%$ e (B) Cristais crescidos na condição Bis-tris 0,1 M (pH6,5), Sulfato de lítio monohidratado 0,2 M, PEG 3350 $25 \%$. Em destaque um zoom dos cristais. 
Os cristais obtidos foram submetidos à difração de raios-X no Laboratório de Cristalografia do IFSC (figura 20). Dois excelentes conjuntos de dados foram coletados, um derivado de NaI (PelD ${ }^{176-455}+$ iodo) e outro em complexo com c-di-GMP (PelD ${ }^{176-455}+$ c-diGMP), ambos provenientes de soakings de cristais nativos em soluções contendo as respectivas moléculas. Os cristais pertencem ao grupo espacial C2 e difrataram até uma resolução máxima de 1,9 e 2,3 $\AA$, PelD ${ }^{176-455}+$ iodo e PelD ${ }^{176-455}+\mathrm{c}$-di-GMP respectivamente.

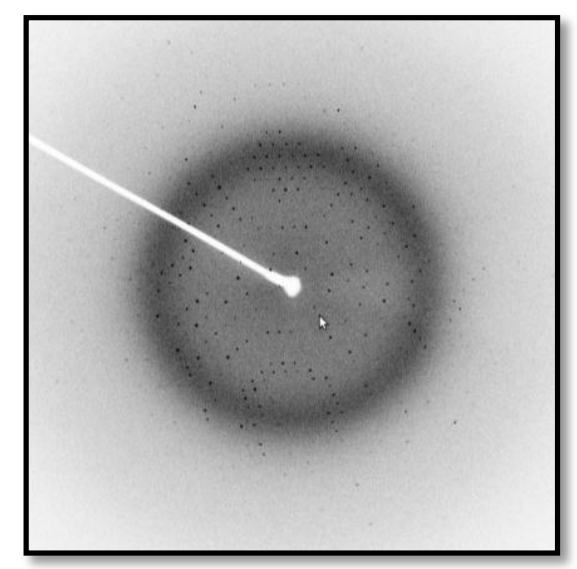

Figura 20 - Imagem do padrão de difração de raios X típico dos cristais pertencentes ao grupo espacial C2 de PelD ${ }^{176-455}$.

Baseando-se na massa molecular calculada para essa construção, uma estimativa para

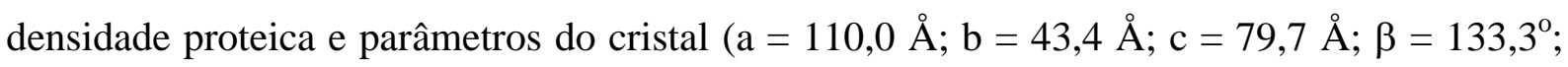
cristal derivado de iodo), apenas uma molécula de PelD ${ }^{176-455}$ ocupa a unidade assimétrica do cristal, que possui um volume de solvente de aproximadamente $45 \%$. A tabela 5 mostra as estatísticas do processamento dos conjuntos coletados, realizado com o programa XDS. $(85,87)$ 
Tabela 5 - Estatísticas da coleta e processamento dos dados de difração de raios X e refinamento das estruturas de PelD ${ }^{176-455}$ na forma apo e complexada com c-di-GMP.

\begin{tabular}{|c|c|c|}
\hline Coleta de dados & PelD $_{176-455}$ soaking com iodo & PelD $_{176-455}+$ c-di-GMP \\
\hline Detector & Rigaku 007HF & Rigaku 007HF \\
\hline$\lambda(\AA)$ & 1,5418 & 1,5418 \\
\hline Grupo Espacial & $\mathrm{C} 2$ & $\mathrm{C} 2$ \\
\hline \multicolumn{3}{|l|}{ Parâmetros da cela } \\
\hline a, b, c ( $(\AA)$ & 110,$0 ; 43,4 ; 79.7$ & 110,$2 ; 42,6 ; 80,0$ \\
\hline$\alpha, \beta, \gamma\left({ }^{\circ}\right)$ & 90,$0 ; 133,3 ; 90.0$ & 90,$0 ; 132,5 ; 90,0$ \\
\hline Resolução $(\AA)$ & $1,9(2,01-1,9)^{\mathrm{c}}$ & $2,3(2,42-2,3)^{\mathrm{c}}$ \\
\hline \multicolumn{3}{|l|}{ Número de reflexões } \\
\hline Totais & $93770(12292)^{\mathrm{c}}$ & $64382(9271)^{\mathrm{c}}$ \\
\hline Únicas & $41299(6142)^{\mathrm{c}}$ & $12223(1762)^{c}$ \\
\hline Completeza $(\%)$ & $96,7(89,9)^{\mathrm{c}}$ & $95,3(86,9)^{\mathrm{c}}$ \\
\hline Redundância & $2,3(2,0)^{\mathrm{c}}$ & $5,3(5,3)^{\mathrm{c}}$ \\
\hline$I / \sigma I$ & $12,9(2,5)^{\mathrm{c}}$ & $18,1(6,0)^{\mathrm{c}}$ \\
\hline$R_{\text {meas }}(\%)^{\mathrm{a}}$ & $6,7(44,1)^{\mathrm{c}}$ & $8,2(30,5)^{\mathrm{c}}$ \\
\hline \multicolumn{3}{|l|}{ Refinamento } \\
\hline$R_{\text {work }} / R_{\text {free }}(\%)^{\mathrm{b}}$ & $18,9 / 21,5$ & $20,5 / 25,7$ \\
\hline \multicolumn{3}{|l|}{$\mathrm{RMSD}^{\mathrm{d}}$} \\
\hline Comprimento da ligação (Å) & 0,003 & 0,008 \\
\hline Comprimento dos ângulos $\left(^{\circ}\right)$ & 0,870 & 1,217 \\
\hline \multicolumn{3}{|l|}{ Número de átomos } \\
\hline Proteína & 2120 & 2014 \\
\hline Água & 213 & 81 \\
\hline Iodo & 4 & --- \\
\hline c-di-GMP & --- & 46 \\
\hline \multicolumn{3}{|l|}{ Média dos B-factors $\left(\AA^{2}\right)$} \\
\hline Proteína & 28,1 & 27,6 \\
\hline Água & 35,3 & 35,0 \\
\hline Iodo & 31,2 & --- \\
\hline c-di-GMP & --- & 21,4 \\
\hline \multicolumn{3}{|l|}{ Ramachandram (\%) } \\
\hline Região mais favorável & 92,8 & 93,7 \\
\hline Região permitida & 7,2 & 6,3 \\
\hline Região adicional permitida & 0,0 & 0,0 \\
\hline Região não permitida & 0,0 & 0,0 \\
\hline
\end{tabular}

${ }^{\mathrm{a}} \mathrm{R}_{\text {meas }}=\Sigma_{\mathrm{h}}\left(\mathrm{n}_{\mathrm{h}} / \mathrm{n}_{\mathrm{h}}-1\right)^{1 / 2} \Sigma_{\mathrm{i}}\left|\mathrm{I}_{\mathrm{i}}(\mathrm{h})-<\mathrm{I}(\mathrm{h})>\right| / \Sigma_{\mathrm{h}} \Sigma_{\mathrm{i}} \mathrm{I}_{\mathrm{i}}(\mathrm{h})$, onde $\mathrm{I}_{\mathrm{i}}(\mathrm{h})$ e $<\mathrm{I}(\mathrm{h})>$ são a $\mathrm{i}^{\text {th }}$ intensidade média e $\mathrm{n}_{\mathrm{h}}$ é a multiplicidade de todas as reflexões $\mathrm{h}$ com simetrias equivalentes. (81)

${ }^{\mathrm{b}} \mathrm{R}_{\text {work }}=\Sigma|| \mathrm{F}_{\text {obs }}|-\mathrm{k}| \mathrm{F}_{\text {cal }} \| /\left|\mathrm{F}_{\mathrm{obs}}\right|$, onde o $\mathrm{F}_{\text {cal }}$ é a amplitude do fator de estrutura calculado do modelo e $\mathrm{F}_{\mathrm{obs}}$ é a amplitude do fator de estrutura observado do modelo. $\mathrm{R}_{\text {free }}$ é calculado com base em $5 \%$ do conjunto de reflexões que não é utilizado durante o refinamento. (82)

${ }^{\mathrm{c}}$ Valores entre parênteses referem-se aos valores das faixas de mais alta resolução.

${ }^{\mathrm{d}}$ Desvio da raiz quadrada média do conjunto de parâmetros para estereoquímica ideal.

${ }^{\text {e}}$ Valores calculados através do programa ProCheck. (91) 


\subsubsection{Determinação da estrutura cristalográfica de PelD ${ }^{176-455}$}

A estrutura de PelD ${ }^{176-455}$ foi resolvida pelo método $S A D$ (86), usando a técnica de soaking (82) rápido dos cristais em solução crioprotetora contendo alta concentração de NaI. A partir das posições dos íons de iodo encontrados com o programa SHELXD (87), fases iniciais foram calculadas com o programa PHENIX (88) e melhoradas com procedimentos de modificação de densidade eletrônica. O modelo foi construído e posteriormente refinado com os programas PHENIX (88) e COOT (89) até valores finais de $\mathrm{R}_{\text {factor }}$ e $\mathrm{R}_{\text {free }}$ de $18,9 \%$ e 21,5\%, respectivamente. $\mathrm{O}$ modelo final possui ótima estereoquímica e todos os resíduos foram construídos, com exceção dos primeiros 4 resíduos do N-terminal e de alguns resíduos do loop que conecta as fitas $\beta 3$ e $\beta 4$. Como já mencionado, um segundo conjunto de dados foi coletado a partir de cristais imersos em solução contendo o ligante de c-di-GMP. Essa estrutura foi refinada a 2,3 $\AA$, apresentando estatísticas finais de $R_{\text {factor }}=20,5 \%$ e $R_{\text {free }}=$ 25,7\% (tabela 5). Essa estrutura continha de fato o ligante complexado à proteína e será discutida na seção 4.1.7.

Para validação das estruturas finais, foi utilizado o programa MolProbity (90), que além de fornecer o gráfico de Ramachandran, também analisa contatos atômicos e detecta problemas estéricos no interior das moléculas através do cálculo das ligações de hidrogênio e contatos de van der Waals nas interfaces entre os componentes. Outra ferramenta do programa é a análise do desvio do carbono- $\beta$ em relação à cadeia central (um sinal de que a torção da cadeia lateral subsequente talvez esteja errada). (90) Dados gerados destas análises podem ser visualizados na tabela 6 .

Tabela 6 - Análise dos parâmetros de validação dos dois conjuntos de dados da PelD gerados pelo programa MolProbity (90)

\begin{tabular}{cccc}
\hline Parâmetros analisados & PelD $_{\mathbf{1 7 6 - 4 5 5}}$ com Iodo & PelD $_{\mathbf{1 7 6 - 4 5 5}}+$ c-di-GMP & Referências $^{\text {Clashscore }}{ }^{1}$ \\
$10,04 \AA$ & $3,36 \AA$ & $>0,4 \AA$ \\
Rotâmeros ruins & $7,34 \%$ & $8,53 \%$ & $<1,0 \%$ \\
Desvio C $\beta>0,25 \AA$ & 0 & 0 & 0 \\
Resíduos com ligações ruins & $0,00 \%$ & $0,00 \%$ & $0 \%$ \\
Resíduos com ângulos ruins & $0,37 \%$ & $0,00 \%$ & $<0,1 \%$ \\
\hline${ }^{1}$ Número de sobreposições ruins para cada 1000 átomos & &
\end{tabular}

${ }^{1}$ Número de sobreposições ruins para cada 1000 átomos 
Outro método de validação foi à verificação detalhada da estereoquímica da estrutura proteica através da análise gráfica dos ângulos diedros da cadeia principal. Um dos gráficos gerados pelos programas MolProbity (90) e Procheck (91) é o Ramachandran (82,90-91), que cruza os valores dos ângulos $\phi$ (phi) e $\psi$ (psi) de modo que eles apresentem-se em combinações preferenciais de seus valores, com base na conformação e na menor energia de ligação dos resíduos. Desvios na conformação preferencial dos resíduos são usados para indicar possíveis erros na estrutura. O gráfico de Ramachandran divide-se em quatro áreas: área amplamente favorável, área adicional permitida, área amplamente permitida e área não permitida. (82) Em um modelo considerado ideal, o número de resíduos encontrados na área não permitida deve ser inferior a $0,5 \%$, sendo que valores próximos ou acima de 0,5 são incomum, os resíduos na área amplamente favorável deve ser igual ou superior a 90\%. (82)

Para PelD ${ }^{176-455}$ o gráfico de Ramachandran pode ser observado na figura 21 , onde mostra que a maioria dos resíduos encontram-se em regiões amplamente favoráveis para os dois conjuntos de dados analisados. Ambos foram gerados pelo programa MolProbity. (90) Os valores correspondentes a cada região do gráfico estão descritos na tabela 7, que mostra os valores gerados pelo Procheck. (91) Os mesmos estão de acordo com MolProbity (90) e apresentam valores dentro dos parâmetros aceitáveis, indicando alta qualidade estrutural.

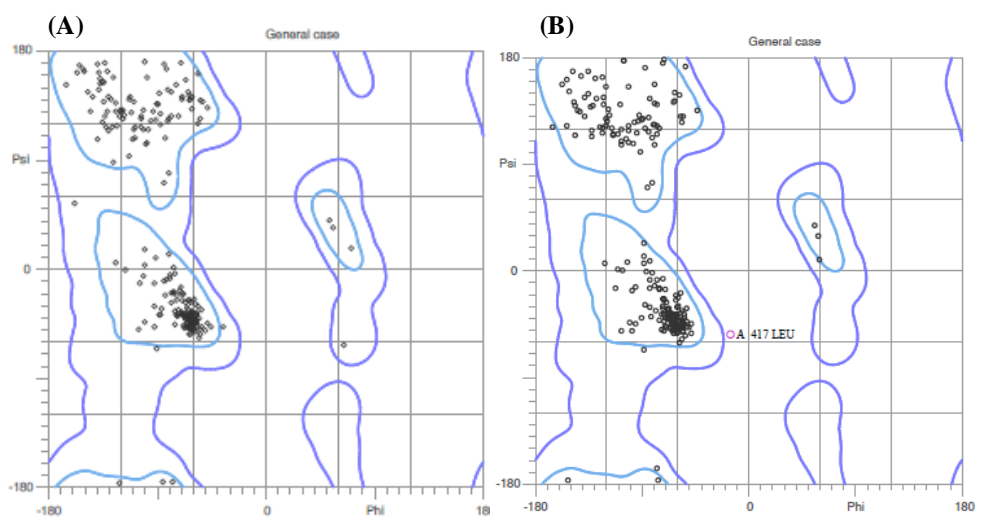

Figura 21 - Diagrama de Ramachandran (90) mostrando a distribuição dos ângulos $\phi$ e $\psi$ de cada resíduo, para os dois conjunto de dados (A) PelD ${ }^{176-455}$ soaking com Iodo e (B) PelD ${ }^{176-455}+\mathrm{c}$-di-GMP. As áreas rodeadas em azul claro representam as conformações que não envolvem sobreposição estérica e, portanto, são totalmente permitidas. As áreas em azul escuro indicam as conformações permitidas nos limites extremos de contatos atômicos desfavoráveis.

Análises energéticas de interação na rede cristalina (servidor PISA) revelaram que PelD ${ }^{176-455}$ é um monômero, com uma molécula na unidade assimétrica. Como esperado, o N- 
terminal apresenta o domínio GAF, que se conecta ao domínio GGDEF degenerado por um loop compreendendo os resíduos 307-320. Este loop encontra-se entre a hélice $\alpha 4$ do domínio GAF e hélice $\alpha 1$ do domínio GGDEF (figura 22). O domínio GAF é composto por quatro hélices $\alpha$ e cinco fitas $\beta$, com a seguinte topologia $\alpha \beta \beta \alpha \beta \beta \beta \alpha \alpha$. A parte central do domínio é composta por cinco fitas $\beta(\beta 1, \beta 2, \beta 3, \beta 4$ e $\beta 5)$ antiparalelas, rodeadas por quatro hélices $\alpha$ $(\alpha 1, \alpha 2, \alpha 3$ e $\alpha 4)$ de tamanho variado (figura 22). O domínio GGDEF também é composto principalmente por $\alpha / \beta$, e apresenta a seguinte topologia $\alpha \beta \alpha \beta \beta \alpha \alpha \beta \alpha$, tendo sua parte central composta por fitas $\beta(\beta 6, \beta 7, \beta 8, \beta 9)$ antiparalela. As fitas $\beta$ centrais são rodeadas por hélices $\alpha$ que ficam expostas ao solvente. Resíduos envolvidos na ligação com c-di-GMP se localizam em dois segmentos: o primeiro compreende o loop conectando $\alpha 6$ e $\beta 7\left(\mathrm{R}^{367} \mathrm{XxD}^{370}\right)$ e o segundo corresponde aos resíduos $\mathrm{T}^{391}$ no loop que fica entre $\beta 8$ e $7 \alpha$ e $\left(\mathrm{R}^{402}\right)$ na hélice $\alpha 7$.

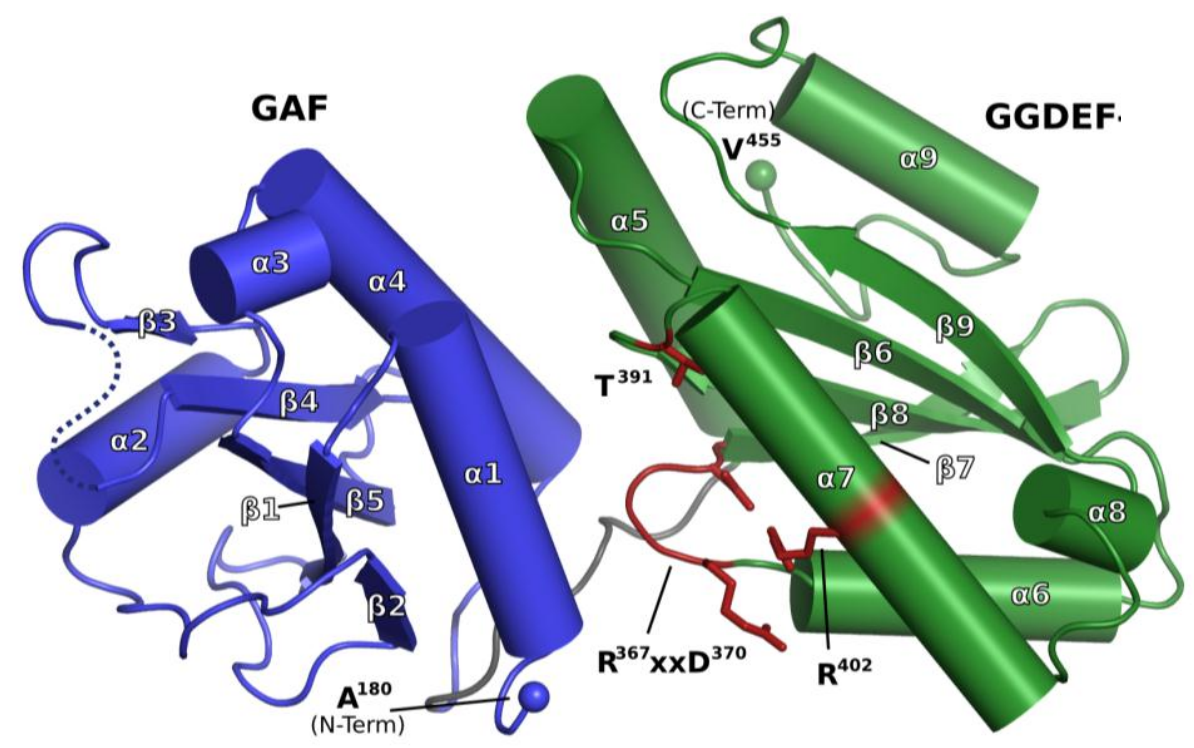

Figura 22 - Análise topológica da estrutura tridimensional da proteína PelD ${ }^{176-455}$ correspondendo no N-terminal de uma $\mathrm{A}^{180}$ e no C-terminal uma $\mathrm{V}^{455}$. Em azul o domínio GAF, em verde o domínio GGDEF degenerado e em vermelho os resíduos envolvidos na ligação com c-di-GMP; o primeiro segmento consiste $\alpha 6-\beta 7:\left(\mathrm{R}^{367} \mathrm{xxD}^{370}\right)$ e o segundo $\beta 8-\alpha 7: \mathrm{T}^{391}$ e $\mathrm{R}^{402}$. Imagem gerada pelo pymol (93)

\subsubsection{Análise dos domínios conservados de PelD ${ }^{176-455}$}

Foi realizada uma análise da estrutura tridimensional com cada domínio de PelD ${ }^{176-455}$ através do servidor DALI (94), que analisa as estruturas dos domínios contra um banco de dados de proteínas (PDB), revelando semelhanças biologicamente interessantes que não são 
detectáveis quando de compara as sequências primárias. Assim, várias proteínas com identidade significativa ao domínio GAF de PelD foram identificadas, dentre elas, a histidina kinase DosS (95) (código PDB: 2WEG) de Mycobacterium tuberculosis. Apesar de uma similaridade sequencial de apenas 11\%, 98 resíduos do domínio GAF foram sobrepostos (C $\alpha$ ), com r.m.s.d. de 2,4 $\AA$ (figura 23). No entanto, mesmo apresentando uma identidade estrutural considerável em ambas proteínas, o domínio GAF apresenta diferentes funções. Para DosS de M. Tuberculosis o GAF desempenha o papel de domínio sensor, em resposta à limitação de oxigênio no meio. Entretanto, esta proteína faz parte de um sistema regulatório de dois componentes, onde se liga a outra proteína (DosT) contendo um tipo diferente de domínio GAF, o GAF B. (95)

(A)

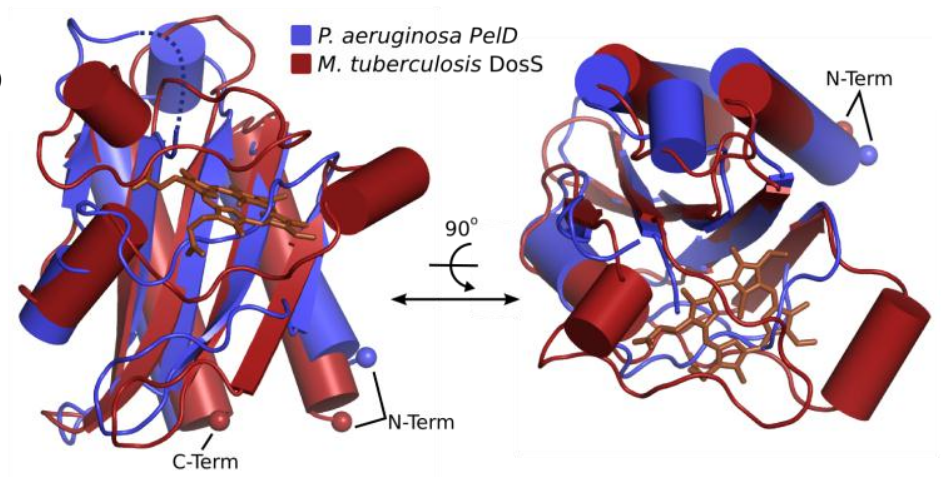

( B )

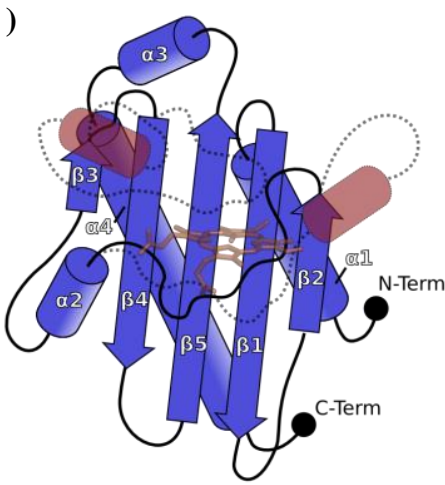

Figura 23 - Comparação estrutural dos domínios GAF. Em azul PelD de P. aeruginosa e em vermelho a histidina kinase DosS de M. tuberculosis. (A) Sobreposição do domínio GAF conservado nas duas proteínas, mostrando pequenas diferenças e (B) Diagrama topológico destacando as duas pequenas hélices $\alpha$ em oposição a PelD. Imagem gerada pelo pymol (93)

É também pertinente observar que domínios GAF podem funcionar como domínios de ligação a cGMP ou cAMP, no entanto estudos mostraram por meio de experiências bioquímicas que em PelD, o mesmo não se liga a mononucleotídeos cíclicos. (95)

Em PelD o domínio GGDEF é topologicamente semelhante a outros domínios GGDEF. (96) No entanto, em PelD o GGDEF possui aproximadamente 20-25 resíduos a menos do que em outros equivalentes. Por exemplo, o C-terminal do PelD mostra uma arquitetura semelhante ao domínio GGDEF encontrado PleD de Caulobacter vibrioides $(56,97$ ) (código PDB: 2V0N) uma diguanilato ciclase ativa (figura 24). Apesar da alta semelhança tridimensional (127 C $\alpha$ sobrepostos com r.m.s.d. de 2,1 $\AA$ ), a identidade 
sequencial fica em apenas $17 \%$. A principal diferença topológica do domínio de PelD, em relação aos GGDEFs clássicos, consiste na ausência da última fita $\beta$ da folha central (fita $\beta 8$ de PleD, figura 24), sendo que a hélice $\alpha 9$ que faz conexão com essa fita (hélice $\alpha$ de PelD e PleD, figura 24) possui uma orientação diferente em PelD (figura 24).

(A)

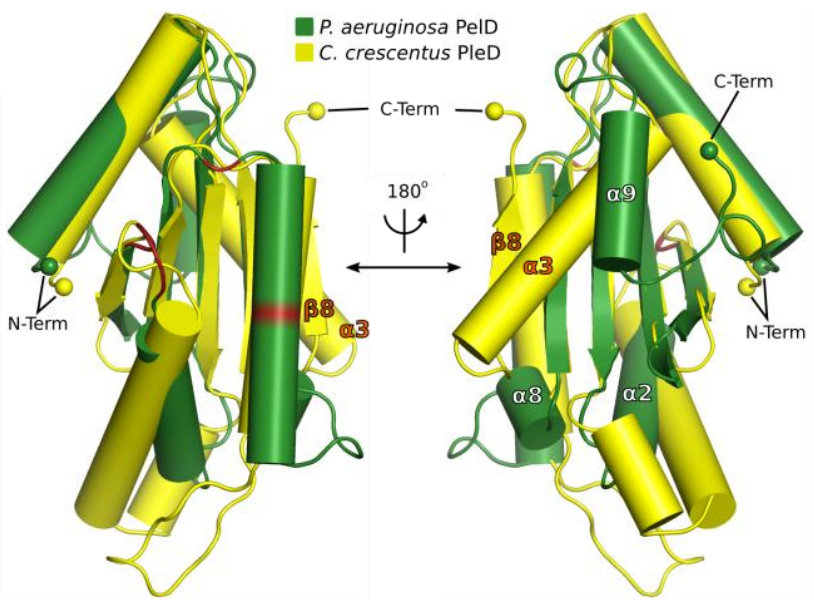

( B )

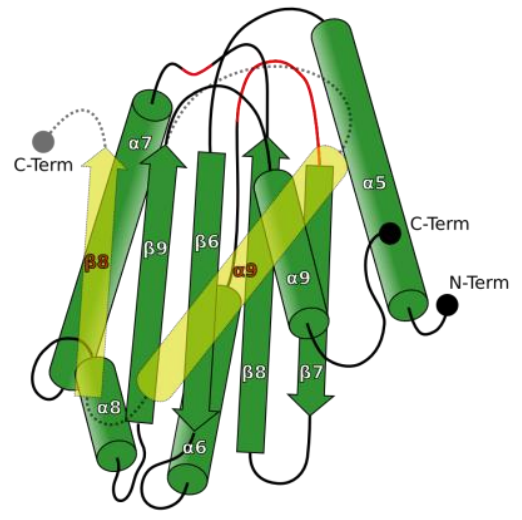

Figura 24 - Comparação estrutural dos domínios GGDEF de PelD de $P$. aeruginosa em verde e PleD de Caulobacter crescentus (103) em amarelo. (A) Sobreposição do domínio GGDEF conservado nas duas proteínas, mostrando as diferenças estruturais do domínio de PelD; (B) Diagrama topológico de PelD, destacando os principais elementos diferentes dos domínios GGDEF clássicos. Imagem gerada pelo pymol (93)

Em PelD o GGDEF encontrado no C-terminal é degenerado e portanto não desempenha função catalítica, pois os resíduos conservados requeridos para esta característica estão ausentes em sua sequência, sendo encontrados os resíduos RNDEG (29-30) (figura 25). Adicionalmente, a estrutura ainda revelou que as fitas $\beta$ conectadas pelo loop contendo o motivo GGDEF das diguanilato ciclases (fitas $\beta 7$ e $\quad \beta 8$ ) são maiores em PelD, desconfigurando assim toda a estrutura do sítio catalítico característico do domínio GGDEF (figura 25). 


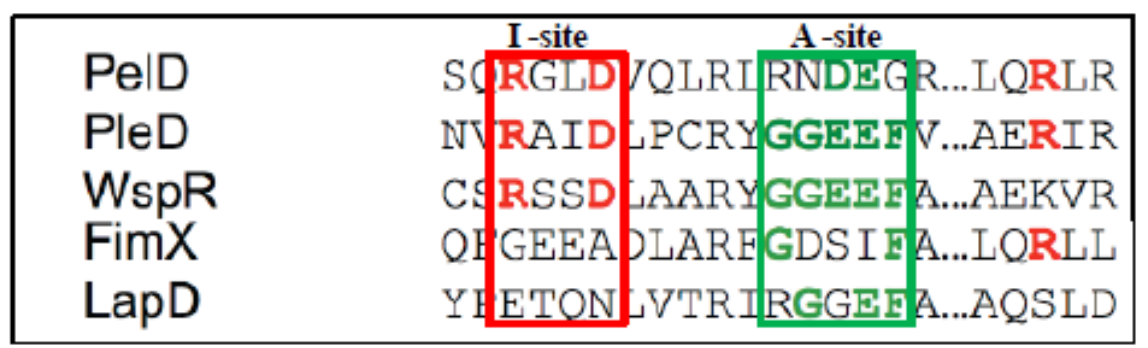

Figura 25 - Alinhamento múltiplo entre a PelD de P. aeruginosa (GGDEF degenerado) e as diversas proteínas que ligam c-di-GMP: PleD de C. crescentus (96) (DGC), WspR de P. fluorescens (97) (DGC), FimX de $P$. aeruginosa (98) (EAL degenerado), LapD de P. fluorescens (99) (EAL degenerado). Em vermelho os resíduos correspondentes ao sítio inibitório (motivo RxxD) e em verde os resíduos sítio ativo (GGD/EF).

No entanto, a proteína é capaz de se ligar a c-di-GMP devido à conservação dos resíduos $\mathrm{R}^{367} \mathrm{xxD}^{370}$ (figura 26), que corresponde ao sítio-I encontrado em diguanilato ciclases, como PleD de Caulobacter crescentus (96), WspR de Pseudomonas aeruginosa (98) e Maqu_2607 de Marinobacter aquaeolei. (29-30)

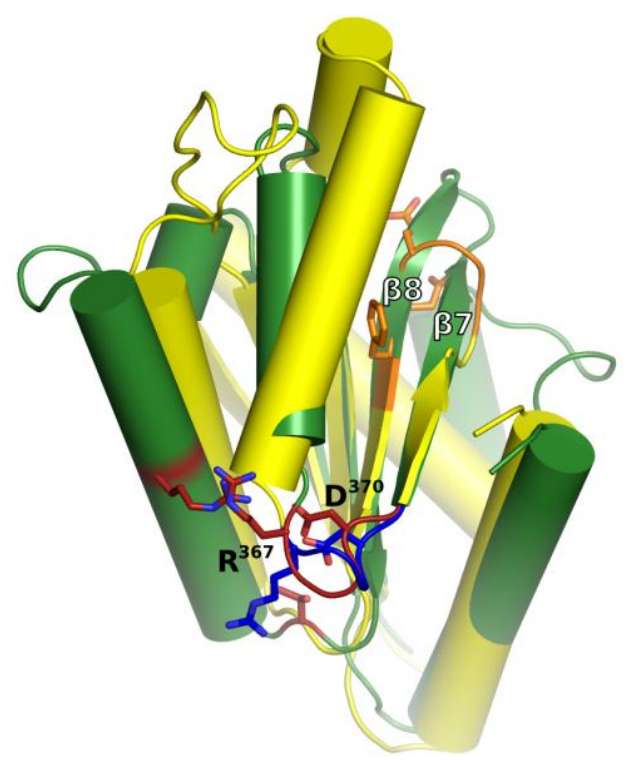

Figura 26 - Sobreposição estrutural do domínio GGDEF de PelD de $P$. aeruginosa (verde) e PleD de $C$. crescentus (amarelo). Em destaque encontram-se os resíduos do motivo GGDEF de PleD (laranja) e dos resíduos que compõem o sítio inibitório das proteínas (PelD em vermelho e PleD em azul). Imagem gerada pelo Pymol (93)

Embora os resíduos $\mathrm{D}^{378}$ e $\mathrm{E}^{379}$, cataliticamente requeridos para coordenação de íon metálico em DGCs, sejam conservados em PelD, eles apontam para longe da posição do "bolsão" de ligação de GTP no sítio ativo e, portanto, não podem contribuir para ligação de substrato ou catálise. Em resumo, a ausência dos resíduos necessários para atividade 
catalítica, bem como grandes diferenças estruturais em relação às diguanilato ciclases ativas, contribuem para a falta de um sítio ativo competente no domínio GGDEF de PelD, tornando assim um domínio GGDEF degenerado, ou seja, sem função catalítica.

Os sistemas efetores envolvendo sinalização através de c-di-GMP mais estudados até o momento, ou até mesmo o mecanismo catalítico das DGC, envolvem grandes mudanças estruturais causadas pela ligação e c-di-GMP. Geralmente o sítio de ligação encontra-se na interface entre domínios, de tal forma que a interação com c-di-GMP quebra essas interfaces e promovem o rearranjo dos domínios, como no caso de LapD de $P$. fluorescens e FimX de $P$. aeruginosa.(99-100) Nesse sentido, apesar do potencial sítio de ligação de c-di-GMP em PelD encontrar-se próximo à interface entre os domínios GAF e GGDEF, provavelmente a ligação dessa molécula não deveria acarretar grandes mudanças estruturais. A interface de interação entre os domínios, que envolve principalmente a hélice $\alpha 4$ do domínio GAF e hélice $\alpha 1$ do domínio GGDEF, apresenta notavelmente uma predominância de resíduos hidrofóbicos, como por exemplo Leu ${ }^{298}$, Leu ${ }^{369}$, Leu ${ }^{390}, \mathrm{Leu}^{340}$ e Ile ${ }^{298}$ (figura 27). Além de conferir estabilidade para estrutura de PelD ${ }^{176-455}$ como um todo, a exposição de tais resíduos ao solvente, o que ocorreria em um eventual rearranjo estrutural, parece ser bastante desfavorável. Adicionalmente, a interação de c-di-GMP com PelD envolve exclusivamente resíduos do domínio GGDEF, como será visto na próxima seção.

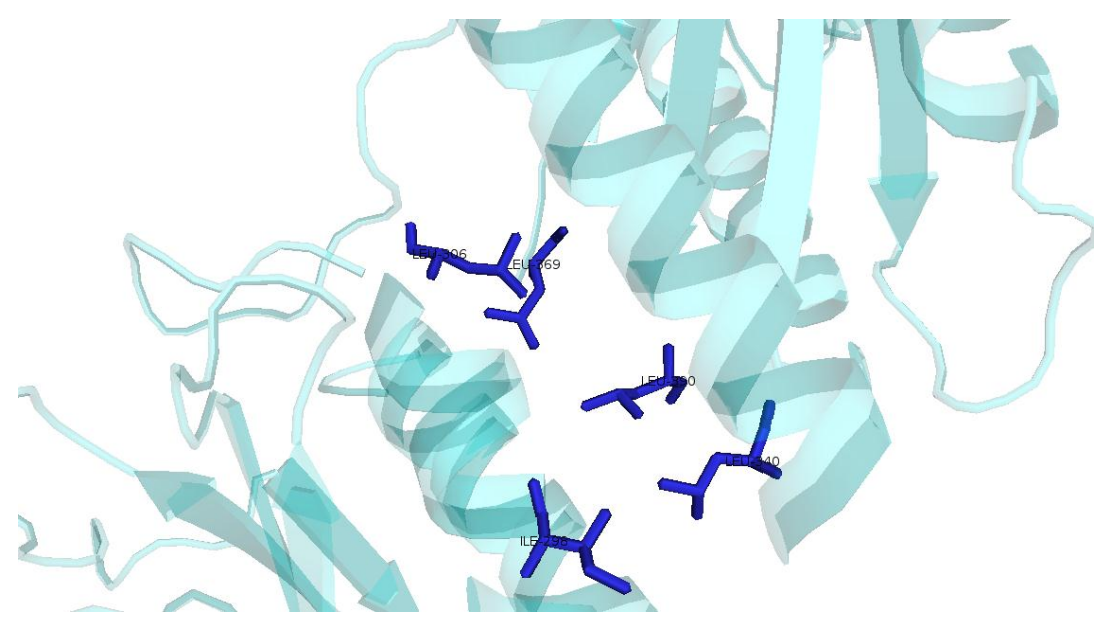

Figura 27 - Representação dos resíduos envolvidos na interação entre os domínios GAF (N-terminal) e GGDEF (C-terminal) de PelD ${ }^{176-455}$. São eles Leu ${ }^{305}, \mathrm{Leu}^{369}, \mathrm{Leu}^{340}, \mathrm{Leu}^{390}, \mathrm{Ile}^{298}$, todos apolares. Imagem gerada pelo programa Pymol. (93) 


\subsubsection{Sítio de ligação de c-di-GMP na estrutura de PelD ${ }^{176-455}$}

A estrutura tridimensional de PelD ${ }^{176-455}$ complexada com o ligante c-di-GMP revelou que apenas uma molécula de c-di-GMP se liga ao degenerado domínio GGDEF, exatamente no sítio-I, previsto como sítio alostérico em DGCs. Este por sua vez, apresenta-se em uma conformação fechada dentro de um "bolsão" aberto e raso, com apenas uma guanina (Gua-1) no "bolsão" e a outra guanina (Gua-2) totalmente exposta ao solvente (figura 28). Os dois anéis de guanina são paralelos um ao outro e ambos são verticalmente ligados a um macrociclo de 12 membros, formado por duas ligações fosfodiéster entre as duas moléculas de GMP, apresentando-se em forma de clipe simétrico. As interações com c-di-GMP ocorrem principalmente através de dois segmentos: um loop composto pelos resíduos $\mathrm{Arg}^{367}$ por $\operatorname{Asp}^{370}$ (motivo RxxD) e um segmento de $\beta$-loop- $\alpha$ englobando a $\mathrm{Thr}^{391} \mathrm{Arg}^{402}$. Dentro destas regiões, os resíduos $\mathrm{Arg}^{367}, \mathrm{Asp}^{370}$, e $\mathrm{Arg}^{402}$ são responsáveis pela maior parte das interações com c-di-GMP. Um dos oxigênios da $\mathrm{Asp}^{370}$ faz uma ligação de hidrogênio com o N-2 de Gua-1, e o segundo forma uma ligação de hidrogênio com N-1 de Gua-1. Já o resíduo Arg ${ }^{402}$ faz ligação de hidrogênio com O-6 e N-7 de Gua-1. A cadeia lateral de Arg ${ }^{367}$, carregado positivamente, interage com os grupos fosfato negativamente carregados do anel de c-di-GMP através de duas moléculas de água. Adicionalmente, o grupo guanidina do mesmo resíduo insere-se no âmbito do anel da Gua-2 e faz interações não covalentes do tipo elétrons $\pi$ com a mesma (figura 28). (29-30)
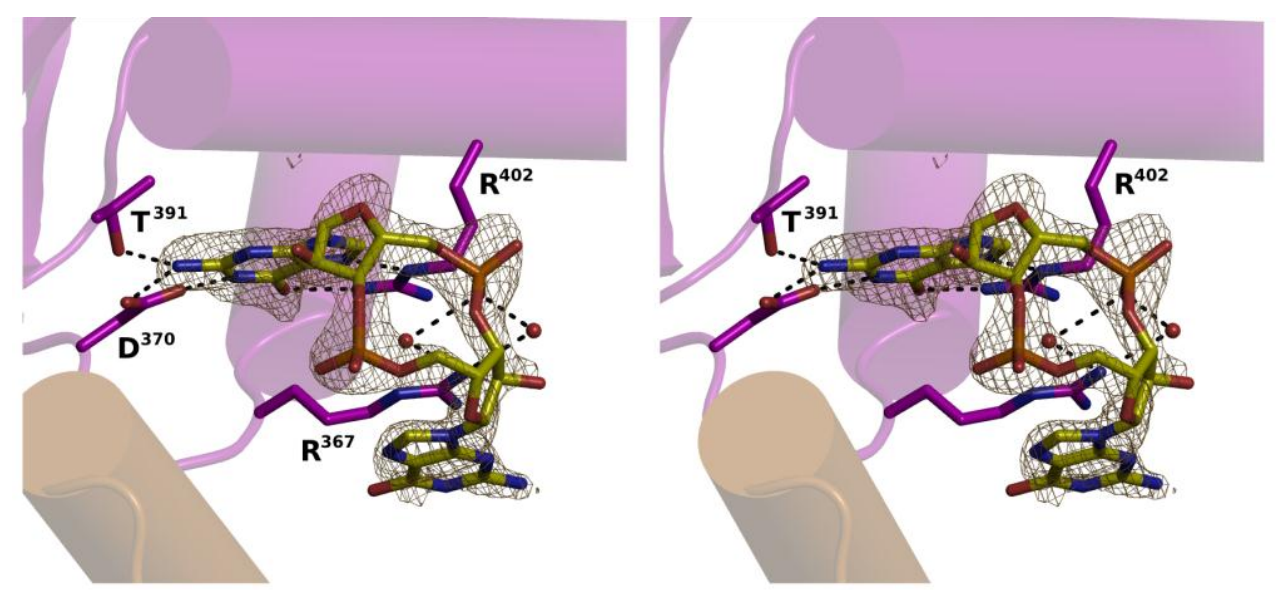

Figura 28 - Visão estéreo da interação de c-di-GMP no sítio de ligação RxxD de PelD. Os principais resíduos de interação estão destacados e o mapa densidade (Fo - Fc) está representado em torno da molécula de c-di-GMP com um contorno de 5 sigma. Imagem gerada pelo programa Pymol. (93) 
Esta ligação de PelD ${ }^{176-455}$ com c-di-GMP em configuração fechada é semelhante às estruturas de cocristalização de PleD (97) ,WspR (98), e do domínio PilZ da proteína VCA0042 de V. Cholera, mas de forma distinta em que FimX (99), LapD (100), em que o cdi-GMP adota uma conformação estendida e inserida em um "bolso" fundo vinculativo.

Além disso, o c-di-GMP pode apresentar-se em várias formas oligoméricas dependendo da solução. Ele pode ser encontrado nas formas dimérica, tetramérica, ou mesmo como agregados maiores, como visto anteriormente. (55) Por exemplo, na presença de magnésio, um cátion divalente, o c-di-GMP apresenta-se na forma dimérica, já na presença de cátion monovalente como o potássio ele pode formar um tetrâmero ou octâmero. Em WspR duas moléculas de c-di-GMP estão intercaladas como dímeros, onde o mesmo se liga e inibe a atividade alostericamente DGC.(98)

Esta forma de ligação c-di-GMP em PelD ${ }^{176-455}$ é surpreendente no contexto de inibição por produto das diguanilato ciclases mais estudas. Nos casos de PleD (97) e WspR (98), por exemplo, o sítio inibitório dos domínios GGDEF são ocupados por duas moléculas intercaladas de c-di-GMP, uma configuração também observada em outros receptores dessa molécula, tal como VpsT de $V$. Cholereae. Esse modo de ligação incomum poderia em um primeiro momento levantar a suspeita de ser artefato irrelevante biologicamente, uma vez que a estrutura foi obtida por soaking do ligante no cristal nativo, o qual poderia induzir um tipo de ligação não nativo. No entanto, muito recentemente, uma construção de PelD (resíduos 158-455) do homólogo muito próximo $P$. aeruginosa PA01 foi resolvida em complexo com cdi-GMP a partir de co-cristalização. (30) O modo de ligação de c-di-GMP é virtualmente idêntico ao observado na estrutura resolvida nesse trabalho, apresentando uma molécula de cdi-GMP no sítio de ligação. Nesse caso a hipótese de artefato fica mais distante já que o complexo foi formado em solução antes da cristalização. Para aumentar o grau de complexidade na compreensão do modo de funcionamento de PelD, à mesma época da estrutura mencionada uma segunda estrutura de PelD, nesse caso uma construção com os resíduos 156-455 de $P$. aeruginosa PA14, foi reportada com 2 moléculas de c-di-GMP intercaladas no sítio de ligação (mesmo modo de interação encontrado nos sítios inibitórios de PleD e WspR). (29-30)

Esse tipo de polimorfismo no modo de ligação de c-di-GMP a receptores já tinha sido observado em algumas proteínas com o domínio PilZ, como VCA0042 de V. Cholera e 
PA4297 de $P$. aeruginosa. Nesses casos a ligação de c-di-GMP no sítio de interação é muito parecida com as encontradas em PelD ${ }^{176-455}$.

\subsubsection{Comparação das estruturas de PelD com e sem c-di-GMP}

Com relação a mudanças estruturais causadas pela ligação de c-di-GMP em PelD, de fato a estrutura praticamente permanece a mesma (r.m.s.d. de $0,7 \AA$ sobre todos os $\mathrm{C} \alpha$ sobrepostos), com exceção do rearranjo de algumas cadeias laterais no sítio de ligação sendo que, como previsto o domínio GAF não participa da interação com o ligante (figura 29).

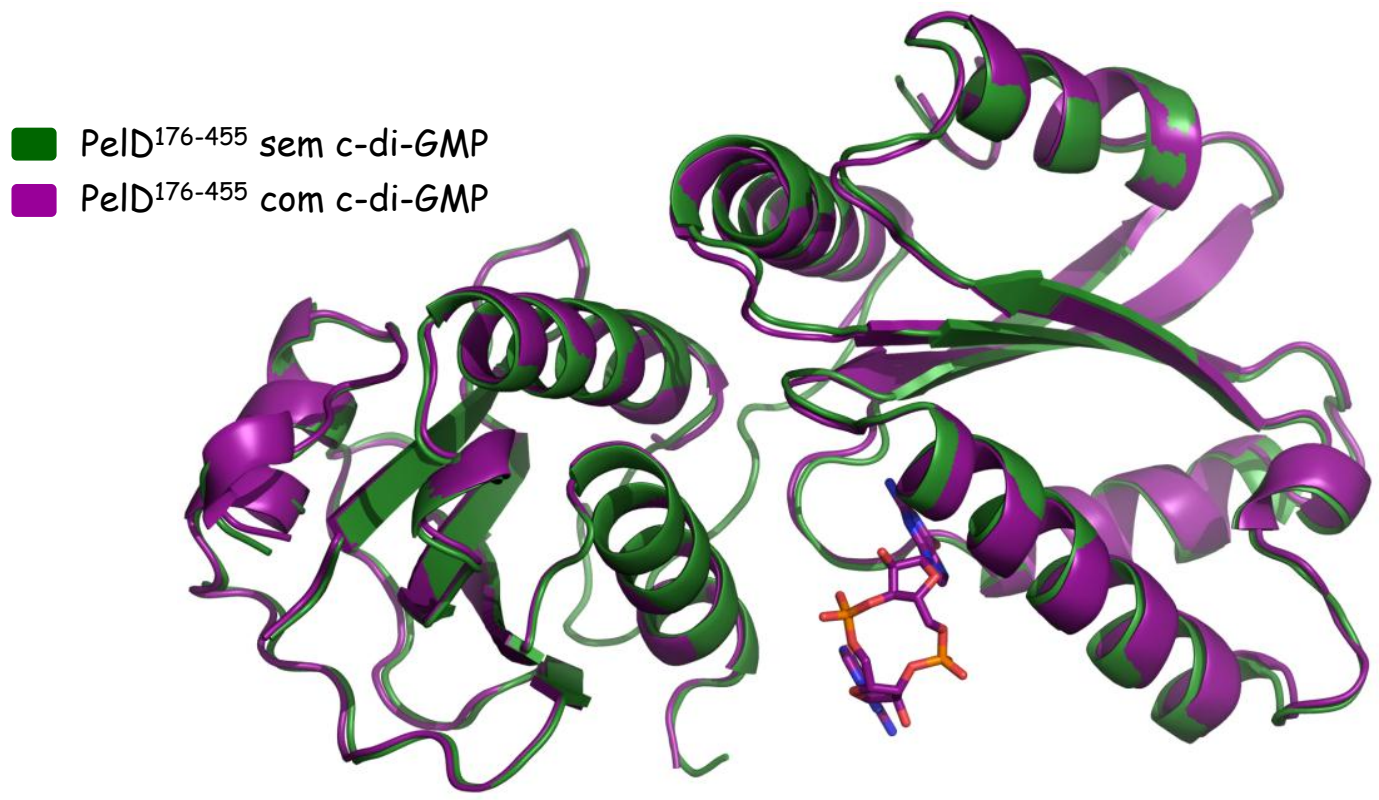

Figura 29 - Sobreposição estrutural das estruturas resolvidas de PelD ${ }^{176-455}$ nas forma com e sem c-di-GMP. Imagem gerada pelo programa Pymol. (93)

\subsubsection{Potencial papel de c-di-GMP na ativação de PelD}

Apesar de termos determinado com sucesso estruturas de uma construção solúvel de PelD tanto com e sem c-di-GMP, a grande semelhança estrutural entre essas formas impossibilitou o levantamento de uma hipótese para o mecanismo de ativação de PelD por cdi-GMP. De fato, em outros sistemas efetores já estudados, os mecanismos de ativação 
envolvem grandes mudanças estruturais ou transição entre formas oligoméricas disparadas pela interação com c-di-GMP, como nos casos do receptor transmembranar LapD de $P$. Fluorescens (100-101) e o fator de transcrição VpsT de V. Cholereae. Pela mesma razão, as estruturas resolvidas por grupos independentes em 2012 (figura 30) também não revelaram o mecanismo de PelD, sendo que o alcance de tais trabalhos limitou-se a uma descrição das estruturas e das bases moleculares de reconhecimento de c-di-GMP. (29-30) Além disso, é válido ressaltar a essas estruturas apresentam praticamente o mesmo número de resíduos de aminoácidos que incluem uma região a mais que a deste trabalho, denominada por nós de hélice sinalizadora ou hélice S. Como podemos observar na figura 30, essa pequena hélice apresenta aminoácidos envolvidos na formação do motivo estrutural coiled-coil (em destaque no gráfico central).

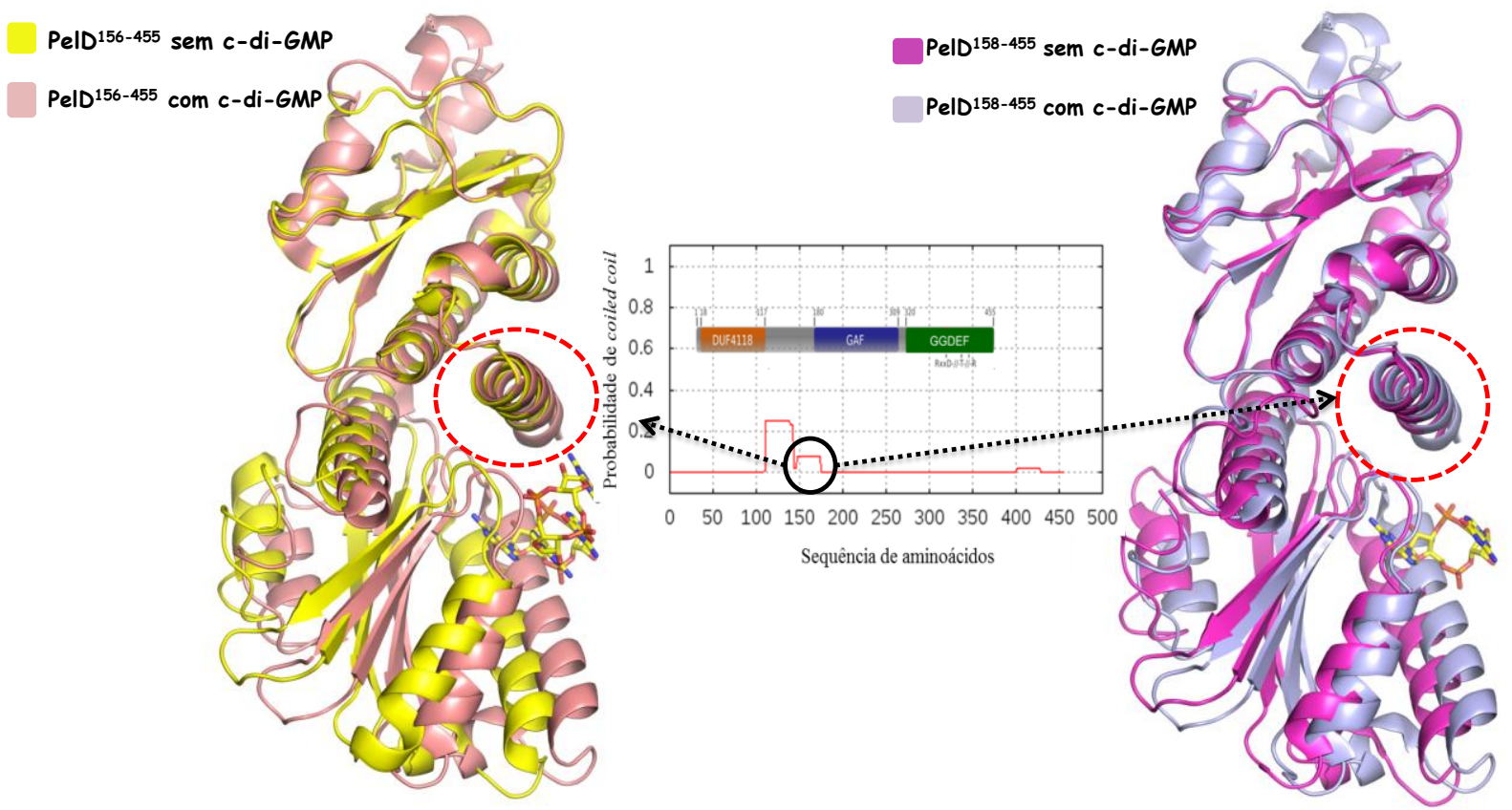

Figura 30 - Sobreposição estrutural das estruturas resolvidas de PelD ${ }^{156-455}$ (4DMZ) de P. aeruginosa PA14 e PelD $^{158-455}$ (4ETZ) de $P$. aeruginosa PA01 nas formas com e sem c-di-GMP. Imagens geradas pelo programa Pymol. (93) Em destaque a hélice- $\alpha$ presente no N-terminal do domínio GAF, região envolvida na predição de coiled-coil.

No entanto, comparando a estrutura deste trabalho com as publicadas, um enorme rearranjo inter-domínios foi observado (rotação de aproximadamente $60^{\circ}$ do domínio GGDEF, com os domínios GAF sobrepostos) (figura 31). 

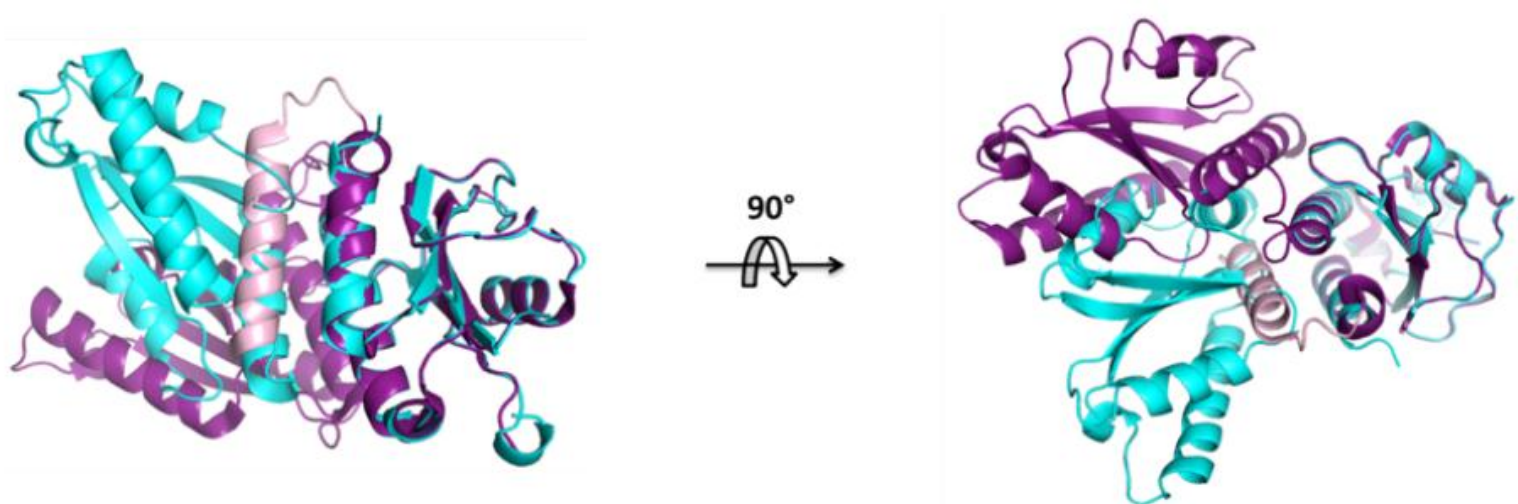

Figura 31 - Visões ortogonais da sobreposição estrutural da construção resolvida no nosso grupo (cyan) e a estrutura 4ETZ (roxo). Na figura a direita fica claro o rearranjo relativo do domínio GGDEF em relação ao domínio GAF. Em rosa está representada a hélice S (resíduos 158-176). Imagem gerada pelo Pymol. (93)

Os resíduos extras (em torno de 20 na porção N-terminal) contidos nas construções cristalizadas nos trabalhos mencionados apresentam uma pequena probabilidade de estarem engajados na continuação do coiled-coil da hélice juxtamembrana de PelD (29-30) No entanto, apesar desse segmento de fato formar uma hélice- $\alpha$, nas estruturas reportadas ela se encontra exatamente na interface entre os domínios GAF e GGDEF de PelD (figura 31, hélice S). Adicionalmente, o sítio de ligação de c-di-GMP envolve interação com essa hélice, sendo que o resíduo $\mathrm{R}^{161}$ coordena os grupos fosfato do c-di-GMP na estrutura que contem a forma dimérica intercalada. Dessa forma, embora independentemente as estruturas apresentadas nesse trabalho e nos dois publicados em 2012 não forneçam bases para proposta do papel de c-di-GMP na ativação de PelD, conjuntamente elas indicam qual deve ser sua função. A ligação de c-di-GMP, provavelmente dimérico intercalado, no sítio-I do domínio GGDEF desestabiliza a interação da hélice no sulco inter-domínios, deslocando-a. Concomitantemente, a exposição de resíduos hidrofóbicos, ora ocluídos na interação com a hélice $S$, induz automaticamente o rearranjo relativo dos domínios GGDEF e GAF de PelD. Nessa proposta, a hélice teria uma função auto-inibitória no mecanismo de ativação, semelhante ao observado em LapD (100) e por esse motivo denominamos esse motivo estrutural de hélice $S$, ou hélice sinalizadora.

De fato, análises estruturais suportam esse papel para c-di-GMP na ativação de PelD. Uma comparação entre as estruturas contendo a hélice extra nas formas apo, com um e dois cdi-GMP mostra um deslocamento progressivo do domínio GGDEF em relação à hélice (figura 32). 


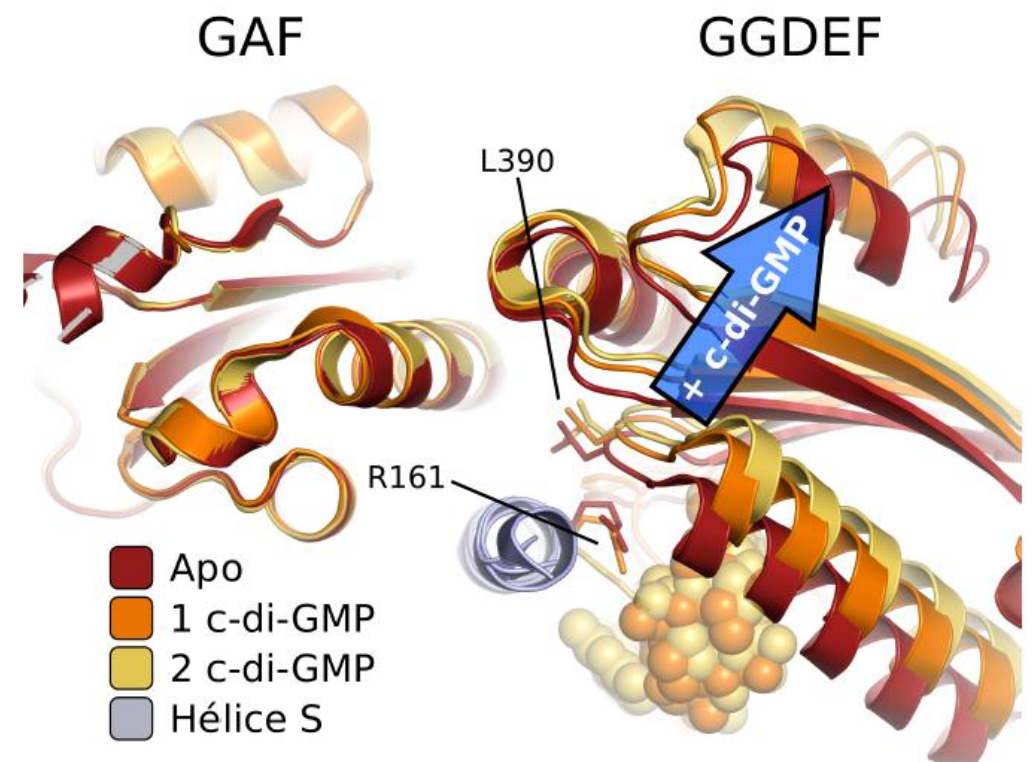

Figura 32 - Comparação estrutural entre as forma apo e complexadas com c-di-GMP de estruturas de PelD contendo a hélice S. Destaque para os resíduos L390, que se afasta da hélice com ligação de c-diGMP, e R161 que interage com a forma dimérica intercalada de c-di-GMP no sítio-I do domínio GGDEF. Imagem gerada pelo Pymol. (93)

Por outro lado, o deslocamento da hélice expõe uma série de resíduos hidrofóbicos dos domínios GAF e GGDEF que estavam em contado com a hélice, os quais estão de fato na interface inter-domínios da estrutura PelD ${ }^{176-455}$. Dessa forma, podemos argumentar que seria energeticamente mais favorável um rearranjo estrutural concomitante ao deslocamento da hélice S (figura 33).

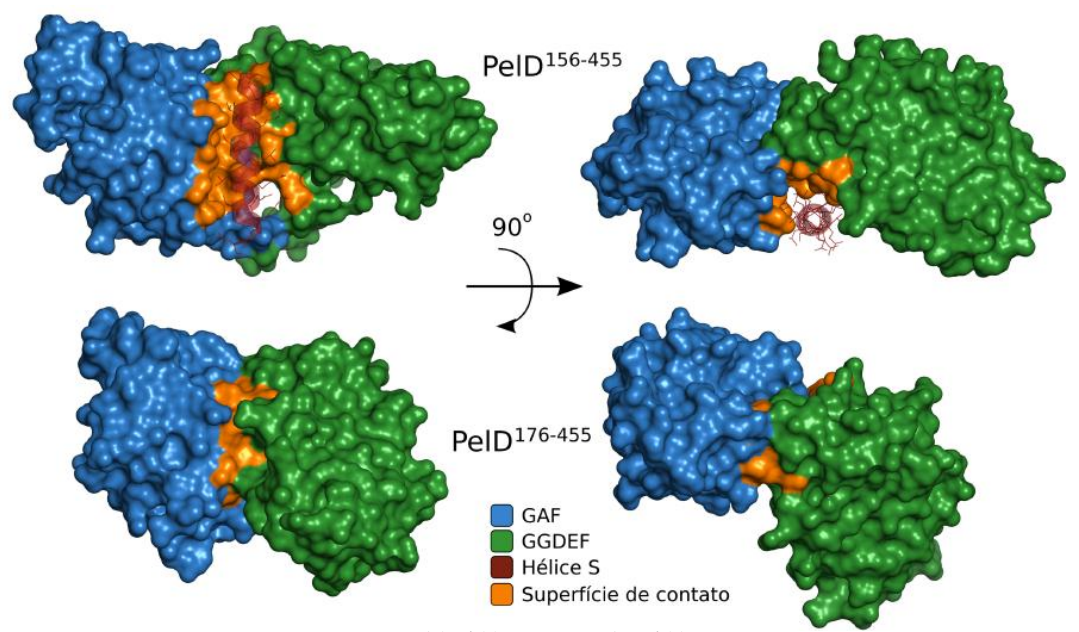

Figura 33 - Superfície das estruturas de PelD ${ }^{156-455}$ e PelD ${ }^{176-455}$ mostrando a superfície de contato (laranja) entre a hélice $\mathrm{S}$ (vermelha) e os domínios GAF (azul) e GGDEF (verde). Imagem gerada pelo Pymol. (93) 
Como essa mudança estrutural poderia estar envolvida com a função de PelD na formação da matriz do biofilme? A resposta para essa pergunta reside essencialmente em como essas mudanças estruturais são transmitidas para o domínio transmembranar de PelD. Uma pista é dada pela propensão de formação de coiled-coil da hélice juxtamenbrana e hélice $\mathrm{S}$, prevista por algorítimos computacionais.

Dessa forma, a seguir apresentamos resultados experimentais de oligomerização e afinidade por c-di-GMP de uma construção contendo toda a parte solúvel de PelD (resíduos 111-455), além da construção cristalizada. Aqui ressaltamos que os trabalhos que apresentaram as estruturas de PelD falharam em conseguir amostra pura de construções contendo a hélice juxtamembrana prevista.

\subsubsection{Afinidade, estequiometria e termodinâmica de ligação de c-di-GMP em PelD}

A técnica de calorimetria de titulação isotérmica foi utilizada para caracterizar termodinamicamente os complexos de PelD ${ }^{111-455}$ e PelD ${ }^{176-455}$ com c-di-GMP. Os dados mostram picos exotérmicos de interação (negativos) e picos endotérmicos (positivos) de diluição do ligante c-di-GMP em tampão Tris-HCl $25 \mathrm{mM}(\mathrm{pH}$ 8,0)/ $\mathrm{NaCl} 500 \mathrm{mM}$ (figura 34).

Ambas as construções de PelD ligam-se a c-di-GMP com afinidade micromolar, no entanto foi observado uma maior constante de dissociação para PelD ${ }^{176-455}$ do que para PelD ${ }^{111-455}$, como pode ser visto na tabela 7 . Isto se deve principalmente à estabilidade das proteínas na forma apo, um dos fatores que interferem na afinidade pelo ligante. Quanto mais instável é a proteína na sua forma apo, mais alto tende ser sua constante de dissociação, devido à grande diferença de energia livre nos estados apo e holo. Como a constante de afinidade é inversamente proporcional à constante de dissociação podemos inferir que neste caso PelD ${ }^{176-455}$ é mais instável e portanto apresenta $K_{d}$ maior. Estes valores estão em boa concordância com estudos anteriores, onde foi usada a técnica de ressonância plasmônica de superfície (26) e obteve-se uma constante de dissociação muito semelhante. Além disso, o ITC permite medir outros parâmetros termodinâmicos importantes, como mostra a tabela 7 . 

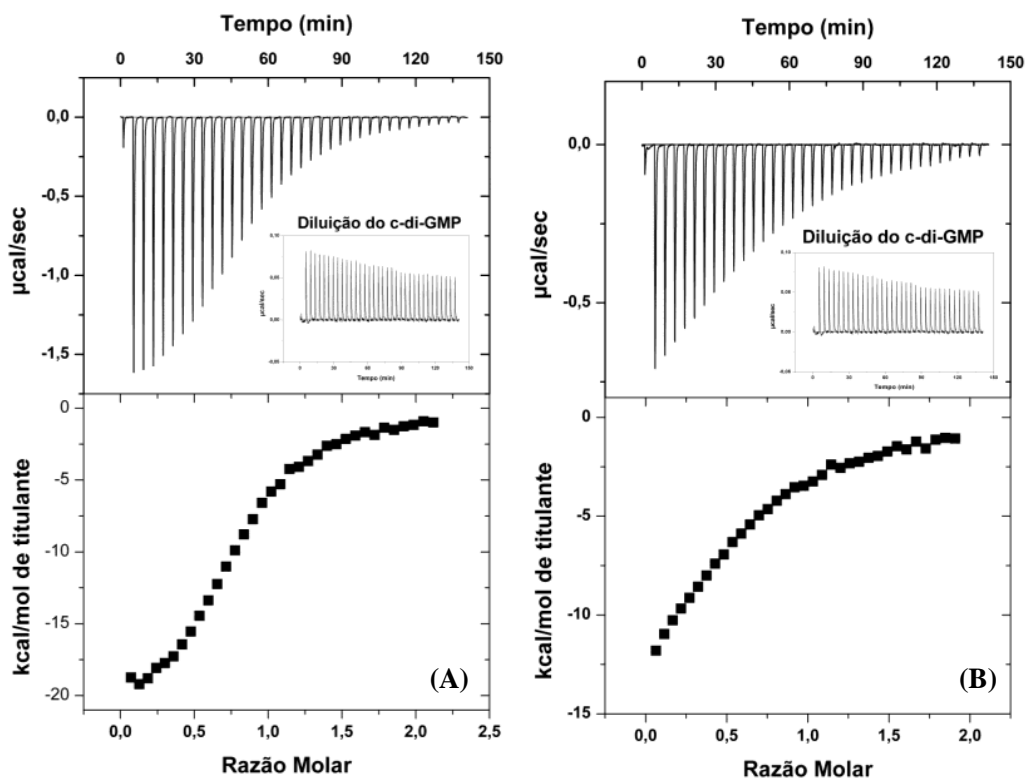

Figura 34 - Termograma da titulação isotérmica de c-di-GMP nas proteínas (A) PelD ${ }^{111-455}$ e (B) PelD ${ }^{176-455}$. O painel superior exibe as injeções e a diluição do ligante em tampão, enquanto que o painel inferior mostra os dados de integração normalizada como uma função.

Para ambas as construções a estequiometria obtida foi de $1: 1$, corroborando com a estrutura cristalina de PelD ${ }^{176-455}$ complexada com c-di-GMP. No entanto, estudos já reportados na literatura mostram que a estequiometria pode ser também de 2:1, pois em uma determinada concentração o c-di-GMP forma dímero em solução ou na presença de diferentes íons metálicos, como já foi mencionado. (29-30)

Tabela 7 - Parâmetros termodinâmicos dos complexos formados pelas duas construções de PelD à uma temperatura de $25^{\circ} \mathrm{C}$.

\begin{tabular}{|c|c|c|c|c|}
\hline Complexos & $\begin{array}{l}\text { Estequiometria } \\
(\mathbf{N})\end{array}$ & $\begin{array}{c}\mathbf{K d} \\
(\mu \mathbf{M})\end{array}$ & $\begin{array}{c}\Delta \mathbf{H} \\
(\mathbf{k c a l} / \mathbf{m o l})\end{array}$ & 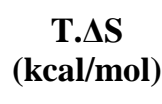 \\
\hline PelD $^{111-455}+c$-di-GMP & $0,8 \pm 0,3$ & $2,2 \pm 0,2$ & $-20,0 \pm 0,4$ & $-41,3 \pm 1,4$ \\
\hline PelD $^{176-455}+$ c-di-GMP & $0,7 \pm 0,3$ & $6,2 \pm 0,4$ & $-17,3 \pm 2,7$ & $-34,4 \pm 9,1$ \\
\hline
\end{tabular}

A interação de ambos os complexos mostra uma entropia desfavorável de ligação. Semelhantes comportamentos termodinâmicos foram observados para a proteína VCA0042 
( $\Delta \mathrm{H}=-25,1 \mathrm{kcal} / \mathrm{mol})$, que contém o domínio PilZ (56), no entanto, a magnitude dos valores é ligeiramente diferente, como mostrado na tabela 7. A entalpia de ligação reflete principalmente a força das interações (ligação de hidrogênio e contatos de van der Waals) entre o ligante e a proteína. Existem dois principais contribuintes para a entalpia de ligação, o primeiro envolve fatores favoráveis em relação à formação de interações não covalentes e segundo envolve os fatores desfavoráveis, que são regidos pela dessolvatação de grupos polares. (74-75)

A análise das estruturas de PelD ${ }^{176-455}$ e VCA0042 quando ligadas a c-di-GMP, revelou uma rede intrincada de interação que explica a entalpia de ligação elevada e favorável. Além disso, o número de ligações de hidrogênio na estrutura VCA0042 é maior do que em PelD refletindo maior afinidade de ligação. Embora PelD e PilZ tenham uma entalpia favorável grande, a ligação de ambos mostrou uma entropia desfavorável. A entropia de ligação está relacionada com alterações nos graus de liberdade do sistema. A formação do complexo restringe conformações do ligante e da proteína e, portanto, resulta em perdas de translação e de rotação da entropia de ligação.

Por outro lado, a liberação de moléculas de água associadas com a oclusão de superfícies hidrofóbicas resulta em uma contribuição entrópica favorável, efeito menos pronunciado. Além do mais, em VCA0042 o c-di-GMP induz uma alteração conformacional após a ligação restringindo a proteína-holo. Isso pode ser associado com a contribuição da entropia desfavorável maior em PelD, onde não se observa o mesmo fenômeno.

\subsubsection{Estudos de oligomerização da porção solúvel de PelD em solução}

Para verificarmos se o estado oligomérico da proteína PelD em solução e eventuais mudanças oligoméricas/conformacionais mediante interação com c-di-GMP, as técnicas de cromatografia de exclusão molecular analítica (SEC) em coluna Superdex 75 10/300 (GE) e ultracentrifugação analítica (técnica de velocidade de sedimentação) foram empregadas. Os experimentos foram realizados com a construção que cristalizou (PelD ${ }^{176-455}$ ), a qual contém os dois domínios citoplasmáticos isolados, e a construção que engloba toda a porção citoplasmática de PelD (PelD ${ }^{111-455}$ ). Este estudo comparativo é particularmente interessante 
dado que as estruturas cristalinas já reportadas na literatura e a apresentada nesse trabalho apresentam-se monoméricas no cristal. Por outro lado, estudos de bioinformática já demonstraram que a região entre o domínio DUF4118 (transmembranar) e o início do domínio GAF compreende uma região de $\sim 70$ resíduos predito como uma hélice juxtamembrana formando um dímero coiled-coil. (29-30) Dessa forma, os experimentos desenhados poderiam confirmar esse estado oligomérico previsto para porção solúvel de PelD.

No caso de SEC analítica, a coluna foi calibrada com cinco proteínas globulares de massa molecular conhecida, preparadas com o mesmo tampão de purificação de PelD (Tris$\mathrm{HCl} 25 \mathrm{mM}(\mathrm{pH} \mathrm{8,0)/} \mathrm{NaCl} 500 \mathrm{mM})$. Os volumes de eluição obtidos a partir dos perfis cromatográficos foram utilizados para montar uma curva de calibração (figura 35), permitindo calcular a massa molecular aparente de PelD ${ }^{111-455}$ (apo e holo) e PelD ${ }^{176-455}$ (apo e holo).

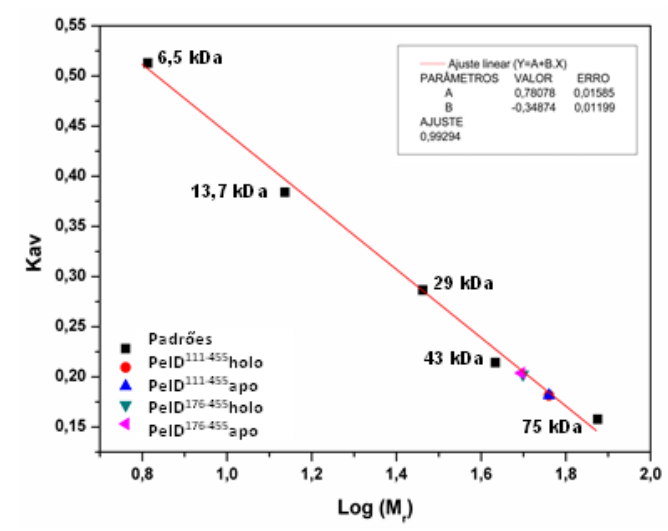

Figura 35 - Gráfico mostrando o coeficiente de partição $\left(\mathrm{K}_{\mathrm{av}}\right)$ versus o log das massas relativas dos padrões e das proteínas de interesse, a reta ajustada aos padrões e os pontos referentes às amostras de PelD nas formas apo e holo.

Utilizando o coeficiente de partição $\left(\mathrm{K}_{\mathrm{av}}\right)$ que representa os volumes de eluição relativo, que pode ser calculado como um parâmetro seguindo a equação (2). As massas das proteínas foram determinadas pela interpolação na regressão linear da curva padrão através dos valores de $\mathrm{K}_{\mathrm{av}}$. Analisando-se o perfil cromatográfico e comparando com os padrões utilizados, observamos que as proteínas em estudo encontram-se entre a Ovalbumina (43 kDa) e a Conalbumina $(75 \mathrm{kDa})$, com pico máximo de eluição em torno de 11,00mL para 
construção PelD ${ }^{111-455}$ e em torno de $11,50 \mathrm{~mL}$ para a construção PelD ${ }^{176-455}$ (figura 36). As massas moleculares aparentes calculadas para PelD ${ }^{111-455}$ tanto na forma apo, quanto na forma holo foram em torno de $53 \mathrm{kDa}$ e para PelD ${ }^{176-455}$ em ambas amostras foi de $44 \mathrm{kDa}$. Considerando que na cromatografia de exclusão por tamanho a massa molecular e a conformação da proteína contribuem para o grau de retenção da mesma (65), estes valores estão em concordância com a massa molecular monomérica de cada uma das construções. No entanto, SEC analítico é uma técnica de não-equilíbrio, onde o equilíbrio de diferentes estados oligoméricos poderia ser deslocado para uma das espécies ao longo da corrida, dada a interação diferencial das formas oligoméricas com o matriz da coluna. Isso pode ter uma interferência alta no caso de baixa afinidade na formação do oligômero, o que pode ser exatamente o caso de PelD ${ }^{111-455}$ uma vez que a truncagem da proteína pode gerar uma forma mais instável e não ideal para formação do oligômero no âmbito do proteína completa.

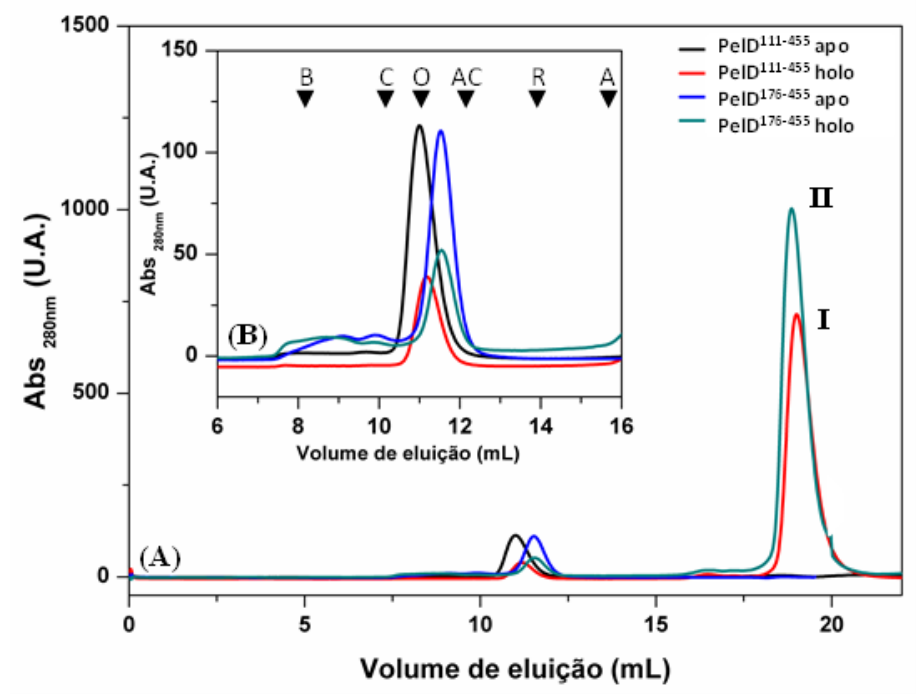

Figura 36 - Perfil cromatográfico das duas construções de PelD na forma apo e complexada com c-di-GMP. (A) Para PelD ${ }^{111-455}$ apo $(\mathrm{Ve}=11,00 \mathrm{~mL})$ e PelD ${ }^{111-455}$ holo $(\mathrm{Ve}=11,18 \mathrm{~mL})$; para PelD ${ }^{176-455}$ apo $(\mathrm{Ve}=$ $11,53 \mathrm{~mL}$ ) e PelD ${ }^{176-455}$ holo ( $\mathrm{Ve}=11,54 \mathrm{~mL}$ ); I e II correspondem a eluição do c-di-GMP; (B) Em destaque os padrões com massas moleculares conhecidas onde B- Blue Dextran, C- conalbumina, Oovalbumina, AC- anidrase carbônica, R-ribonuclease e A- aprotinina.

Diante dos dados obtidos por cromatografia de exclusão por tamanho não poderíamos afirmar com toda certeza que PelD se encontra na forma monomérica em ambas construções. Sendo assim passamos para uma análise das potenciais formas oligoméricas de PelD 
utilizando uma técnica mais absoluta, que não depende da interação das construções em um meio artificial de uma coluna cromatográfica.

Para uma análise mais precisa das formas oligoméricas de PelD ${ }^{111-455}$ e PelD ${ }^{176-455}$ em solução e determinação de seus parâmetros hidrodinâmicos, foi realizado experimentos de AUC. Análises com soluções contendo as proteínas e o ligante não foram possíveis serem realizadas pelo fato do dinucleotídeo (c-di-GMP) absorver em uma grande faixa do espectro, inclusive no mesmo comprimento de onda que a proteína absorve $(280 \mathrm{~nm})$, impossibilitando os ajustes com os softwares disponíveis.

A figura 37A mostra os dados experimentais (símbolos) e os ajustes (linhas) obtidos na AUC em função da absorbância versus a distância radial, para PelD ${ }^{111-455}$ na forma apo a $20{ }^{\circ} \mathrm{C}$ através do software SEDFIT. (72) Na figura 37B é mostrado o perfil dos resíduos obtidos a partir do ajuste dos dados da figura 37A. A distribuição de resíduos mostra a qualidade dos ajustes realizados. Quanto menor a variação em torno do zero melhor é análise dos dados.
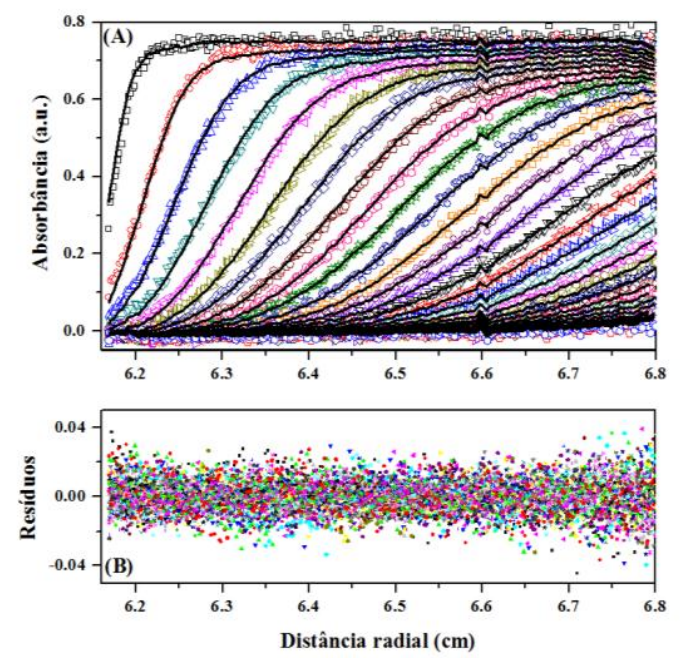

Figura 37 - Dados parciais de velocidade de sedimentação mostrando o ajuste utilizando o software SEDFIT. (76) (A) Curvas de absorbância em $280 \mathrm{~nm}$ versus o raio da cela, para PelD ${ }_{111-455}$ em tampão Tris$\mathrm{HCl} 25 \mathrm{mM}$ (pH 8,0), $\mathrm{NaCl} 500 \mathrm{mM}$. (B) Resíduos fornecidos pelo mesmo software mostrando a qualidade do ajuste.

A partir da figura do ajuste e da distribuição de resíduos pode-se inferir que o método utilizado na análise dos dados foi eficiente, pois há uma sobreposição das curvas experimentais e ajustadas pelo software SEDFIT (70-73), além disso, o RMSD obtido foi de 
apenas $8 \times 10^{-3} \pm 0,02$. As figuras 38A e 38B mostram as distribuições, c(s), dos coeficientes de sedimentação para as duas construções de PelD em três concentrações diferentes. Para evitar erros relacionados a não idealidade da amostra, como variação de temperatura, densidade, viscosidade ou mesmo não homogeneidade do tampão induzidas por $\mathrm{pH}$, força iônica, os valores de $s$ foram transformados para $s_{20, \mathrm{w}}$. Onde o $s_{20, \mathrm{w}}$ corresponde ao coeficiente de sedimentação corrigida, considerando que o solvente seja a água. (72-73)

Para PelD ${ }^{111-455}$, os experimentos de velocidade de sedimentação, no intervalo de concentração de 11 a $56 \mu \mathrm{M}$, indicaram a presença de dois picos principais com o aumento da concentração proteica. O primeiro pico em torno de 2,02 \pm 0,04 corresponde ao monômero e o segundo pico em torno de 2,82 $\pm 0,05$ corresponde ao dímero. Os valores de massa molecular e contribuição percentual para as duas espécies foram de 42,2 $\pm 0,1 \mathrm{kDa}$ e $56 \%$ para o monômero e de 71,0 $\pm 0,2 \mathrm{kDa}$ e $42 \%$ para a espécie dimérica, como mostra a figura 38. Os valores de massa molecular obtidos por AUC a partir dos coeficientes de sedimentação para as duas espécies (42,2 kDa e 71,0 kDa, picos I e II respectivamente) são coerentes com os valores de massa molecular teórica estimadas a partir da sequência de aminoácidos para monômeros e dímeros, respectivamente. A contribuição das espécies é fortemente dependente da concentração de proteína, sendo observada uma maior contribuição do segundo pico na concentração mais elevada. Já para PelD ${ }^{176-455}$, os experimentos indicaram a presença de uma componente principal com coeficiente de sedimentação padrão de $1,7 \pm 0,1$, como mostra a figura 38. Os valores de massa molecular e contribuição percentual para a única espécie presente em solução para essa construção foi de $41,2 \pm 0,1 \mathrm{kDa}$ e $87 \%$, correspondente ao monômero, também coerentes com o valor de massa molecular teórica $(31 \mathrm{kDa})$, estimada a partir da sequência de aminoácidos. 

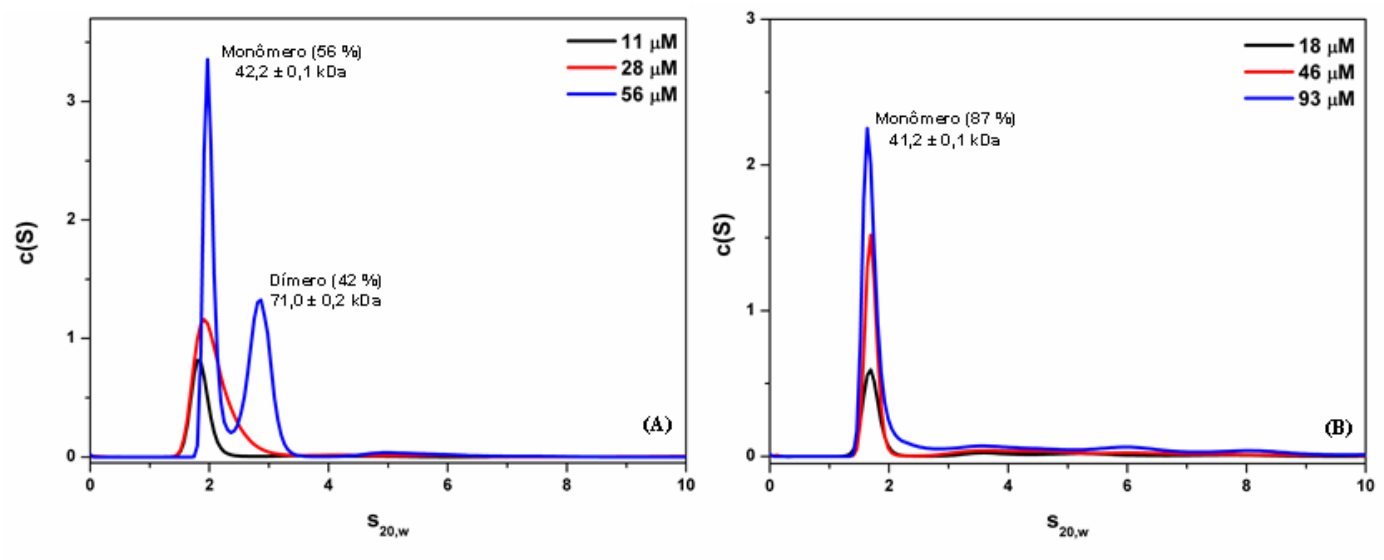

Figura 38 - Experimento de velocidade de sedimentação para as duas construções da PelD em tampão Tris-HCl $25 \mathrm{mM}(\mathrm{pH} 8,0), \mathrm{NaCl} 500 \mathrm{mM}$. (A) para PelD ${ }^{111-455}$ e (B) para PelD ${ }^{176-455}$ no intervalo de concentração correspondente a uma absorbância de 0,2 a 1 .

Desta forma, os dados apresentam um forte indício de que há uma alta heterogeneidade em solução para a construção PelD ${ }^{111-455}$, embora na gel filtração a mesma corresponde a um pico único. Isso indica de forma inequívoca que a presença da região prevista para forma um coiled-coil de fato induz dimerização dessa porção solúvel de PelD. Adicionalmente, a presença de diferentes formas oligoméricas em solução, para essa construção, pode ter impossibilitado sua cristalização. Para a construção PelD ${ }^{176-455}$ o pico único em todas as concentrações analisadas corresponde a uma espécie monomérica em solução, o que possibilitou seus estudos estruturais.

\subsubsection{Análise de dicroísmo circular das duas construções de PelD na forma apo e complexada com c-di-GMP}

Uma vez demonstrado que os resíduos 111-175 da porção solúvel de PelD (presentes na construção PelD ${ }^{111-455}$ ) induzem dimerização da proteína, estudos de Dicroísmo Circular (CD) foram realizados para se tentar determinar qual a provável estrutura secundária que esse resíduos deveriam assumir, e se ligação com c-di-GMP afeta de alguma forma essa estrutura. Utilizando as amostras de PelD ${ }^{111-455}$ e PelD ${ }^{176-455}(0,2 \mathrm{mg} / \mathrm{mL})$ apo e complexada com c-di- 
GMP na proporção de 1:2 experimentos de $\mathrm{CD}$, cujo os espectros são mostrados a seguir na figura 39.
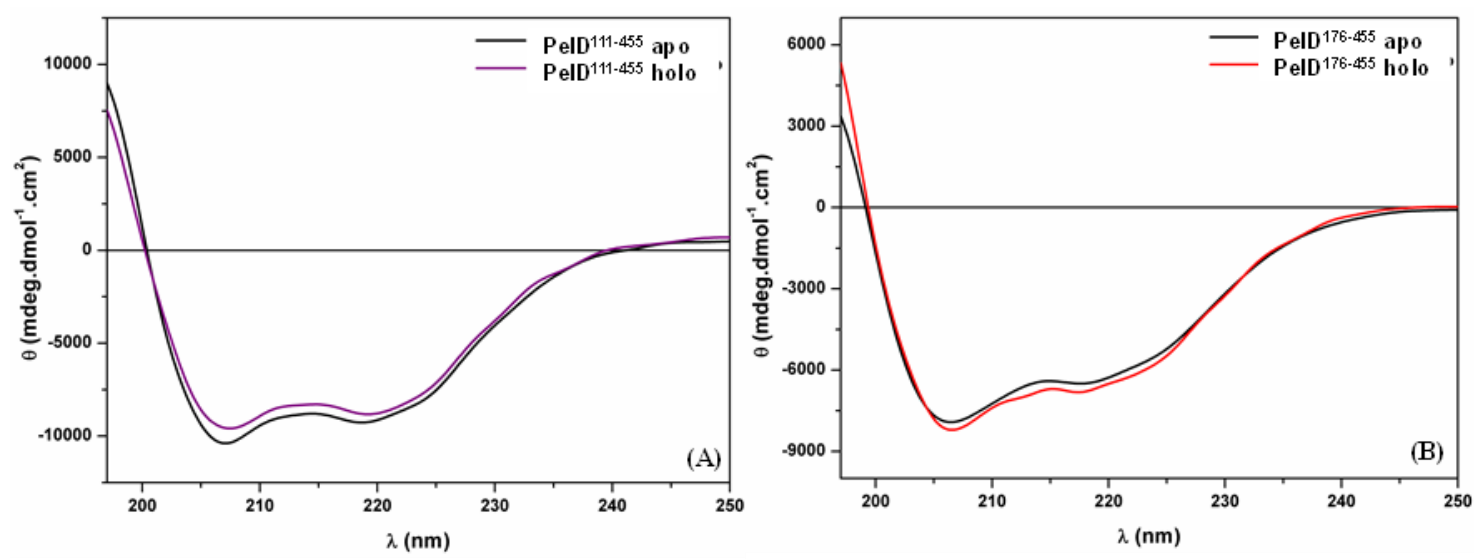

Figura 39 - Espectro de Dicroísmo Circular na região de UV-distante para (A) $\operatorname{PelD}^{111-455}$ e (B) PelD ${ }^{176-455}$ na forma apo e holo (complexada com c-di-GMP).

Notam-se picos negativos em $222 \mathrm{~nm}$ e 208-218 nm em ambos os espectros devido a transições do tipo $n-\pi^{*}$ e $\pi-\pi^{*}$, descrevendo espectros característicos de proteínas ricas em hélices- $\alpha$ e folhas- $\beta$. No entanto, fica claro que o pico em 208-218 nm é mais intenso em PelD ${ }^{176-455}$ em relação ao espectro de PelD ${ }^{11-455}$. Em vista dos espectros característicos de estruturas secundárias distintas (hélices- $\alpha$ e folhas- $\beta$ e coils), uma análise qualitativa dos espectros indica que a proporção de hélices- $\alpha$ em relação a outras estruturas secundárias em PelD ${ }^{176-455}$ é menor que a mesma proporção em PelD ${ }^{111-455}$. Podemos fazer essa afirmativa um vez que em estruturas puramente hélices- $\alpha$ o máximo de absorção em 222 nm é mais intenso que em 208-218 nm. Por outro lado, estruturas secundárias fitas- $\beta$ e coils possuem um único máximo de absorção, mais próximo de 208-218 nm. Essa análise qualitativa demonstra que a região 111-175 provavelmente se enovela em uma hélice- $\alpha$. Uma análise mais quantitativa foi realizada com a deconvolução dos espectros experimentais, por meio do programa CDpro (79-80) (tabela 8). 
Tabela 8 - Porcentagem de estruturas secundárias das proteínas recombinantes PelD ${ }^{111-455}$ e PelD ${ }^{176-455}$ (sem e com c-di-GMP). Obtidas pelo programa CDpro. (80)

\begin{tabular}{|c|c|c|c|c|}
\hline & \multicolumn{4}{|c|}{ PelD $^{111-455}$ (sem c-di-GMP) } \\
\hline & Hélice- $\alpha(\%)$ & Folha- $\beta(\%)$ & Voltas (\%) & Randômica (\%) \\
\hline SELCON 3 & 25,8 & 22,1 & 21,7 & 27,9 \\
\hline CONTINLL & 27,5 & 22,4 & 20,7 & 29,4 \\
\hline \multirow[t]{3}{*}{ CDSSTR } & 25,0 & 26,9 & 18,8 & 29,2 \\
\hline & \multicolumn{4}{|c|}{ PelD $111-455$ (com c-di-GMP) } \\
\hline & Hélice- $\alpha(\%)$ & Folha- $\beta(\%)$ & Voltas $(\%)$ & Randômica (\%) \\
\hline SELCON 3 & 22,1 & 25,8 & 21,8 & 28,4 \\
\hline CONTINLL & 24,2 & 24,2 & 20,2 & 31,4 \\
\hline \multirow[t]{3}{*}{ CDSSTR } & 21,5 & 27,3 & 20,6 & 30,6 \\
\hline & \multicolumn{4}{|c|}{ PelD $176-455$ (sem c-di-GMP) } \\
\hline & Hélice- $\alpha(\%)$ & Folha- $\beta$ (\%) & Voltas (\%) & Randômica (\%) \\
\hline SELCON 3 & 17,0 & 29,6 & 21,0 & 24,3 \\
\hline CONTINLL & 18,0 & 29,8 & 21,9 & 30,3 \\
\hline \multirow[t]{3}{*}{ CDSSTR } & 17,3 & 29,1 & 22,2 & 30,5 \\
\hline & \multicolumn{4}{|c|}{ PelD $^{176-455}$ (com c-di-GMP) } \\
\hline & Hélice- $\alpha(\%)$ & Folha- $\beta(\%)$ & Voltas (\%) & Randômica (\%) \\
\hline SELCON 3 & 16,5 & 30,2 & 20,8 & 23,8 \\
\hline CONTINLL & 19,5 & 28,4 & 21,1 & 31,0 \\
\hline CDSSTR & 18,4 & 29,0 & 22,0 & 30,3 \\
\hline
\end{tabular}

Uma comparação entre os resultados experimentais e teóricos indica um resultado de deconvolução aceitável, apesar de o programa CDpro utilizar um banco de dados com poucas proteínas. (79-80) Como esperado, há uma porcentagem de hélices- $\alpha$ maior para PelD ${ }^{111-455}$ relação a PelD ${ }^{176-455}$, o que confirma as predições de estruturas secundárias utilizando as ferramentas computacionais. Outro fator importante é que a ligação do ligante em ambas as proteínas não altera significativamente seu espectro e tão pouco as porcentagens de estruturas secundárias. 


\section{Papitulo 5}

5 Ponclusões e perspectivas

Neste capítulo serão apresentadas as principais conclusões alcançadas neste trabalho, bem como as perspectivas previstas para a continuação de outros estudos frente às diversas proteínas envolvidas na via de sinalização mediada por c-di-GMP em $P$. aeruginosa (PA14). 


\subsection{CONCLUSÕES}

O trabalho aqui apresentado teve como foco o estudo biofísico e estrutural de construções solúveis da proteína PelD de Pseudomonas aeruginosa (PA14), com e sem o dinucleotídeo c-di-GMP. Nossa contribuição para tanto se baseou na determinação dos protocolos de clonagem, expressão e purificação, bem como o estudo estrutural culminando no reconhecimento das bases moleculares de interação com c-di-GMP.

Estudos de oligomerização sem e com c-di-GMP demonstraram experimentalmente que a porção solúvel de PelD forma um dímero através do motivo estrutural coiled-coil na região entre o domínio transmembranar (DUF4118) e o domínio GAF. Finalmente, nesse trabalho também foi realizada a determinação de parâmetros termodinâmicos frente à ligação com o c-di-GMP, utilizando técnicas analíticas e físico-químicas aqui descritas.

A ligação de uma molécula de c-di-GMP ao domínio GGDEF degenerado de PelD, coloca definitivamente esta proteína na lista de uma nova classe de receptores deste segundo mensageiro em bactérias. Além disso, características bastante diferenciadas e peculiares foram observadas em PelD, como os diferentes modos de ligação de c-di-GMP no sítio de reconhecimento. $\mathrm{O}$ fato de uma ou duas moléculas intercaladas se ligarem ao sítio, em adição ao mesmo fenômeno observado para outra proteína contendo o domínio PilZ, pode indicar que o polimorfismo de ligação de c-di-GMP a um mesmo receptor possa desencadear respostas distintas, adicionando uma nova camada de complexidade nas vias de sinalização mediadas por c-di-GMP.

Por outro lado, uma comparação das estruturas com e sem c-di-GMP não indicaram mudanças conformacionais significativas, o que seria no mínimo curioso em se tratando de receptores de c-di-GMP. Dado a vasta gama de exemplos de proteínas que apresentam grandes mudanças conformacionais disparadas pela ligação do nucleotídeo (domínios PilZ, LapD, FimX, VpsT, por exemplo). Estruturas de diferentes construções de PelD reportadas recentemente foram providenciais para elucidação desse mistério. Com base nas análises estruturais e nos resultados dos experimentos de oligomerização e afinidade por c-di-GMP em solução, podemos propor um mecanismo para ativação de PelD na exportação do polissacarídeo pel para fora da célula (figura 40). 
$\mathrm{Na}$ ausência de c-di-GMP, PelD dimérica encontra-se na forma auto-inibida com a hélice $\mathrm{S}$ interagindo no bolsão hidrofóbico entre os domínios GAF e GGDEF de cada um do monômeros. Mudanças ambientais que promovam aumentos dos níveis intracelulares dessa molécula levam a ligação de c-di-GMP ao sítio-I dos domínios GGDEF de PelD, promovendo o deslocamento da hélice $S$ da sua posição inicial e concomitante rearranjo estrutural interdomínios. Como a hélice $\mathrm{S}$ é uma continuação do coiled-coil juxtamembrana previsto e comprovado nos nossos experimentos, a hipótese mais provável é que uma vez deslocadas do sulco interdomínio, as hélices $\mathrm{S}$ de cada monômero de PelD interajam entre si, propagando dessa forma a mudança conformacional para o domínio transmembranar DUF4118 de PelD. Nesse estado ativado, provavelmente a interação de PelD com a única glicosiltransferase (PelF) do operon pel é favorecida, permitindo que o polímero seja sintetizado a medida que é exportado para o periplasma da célula.

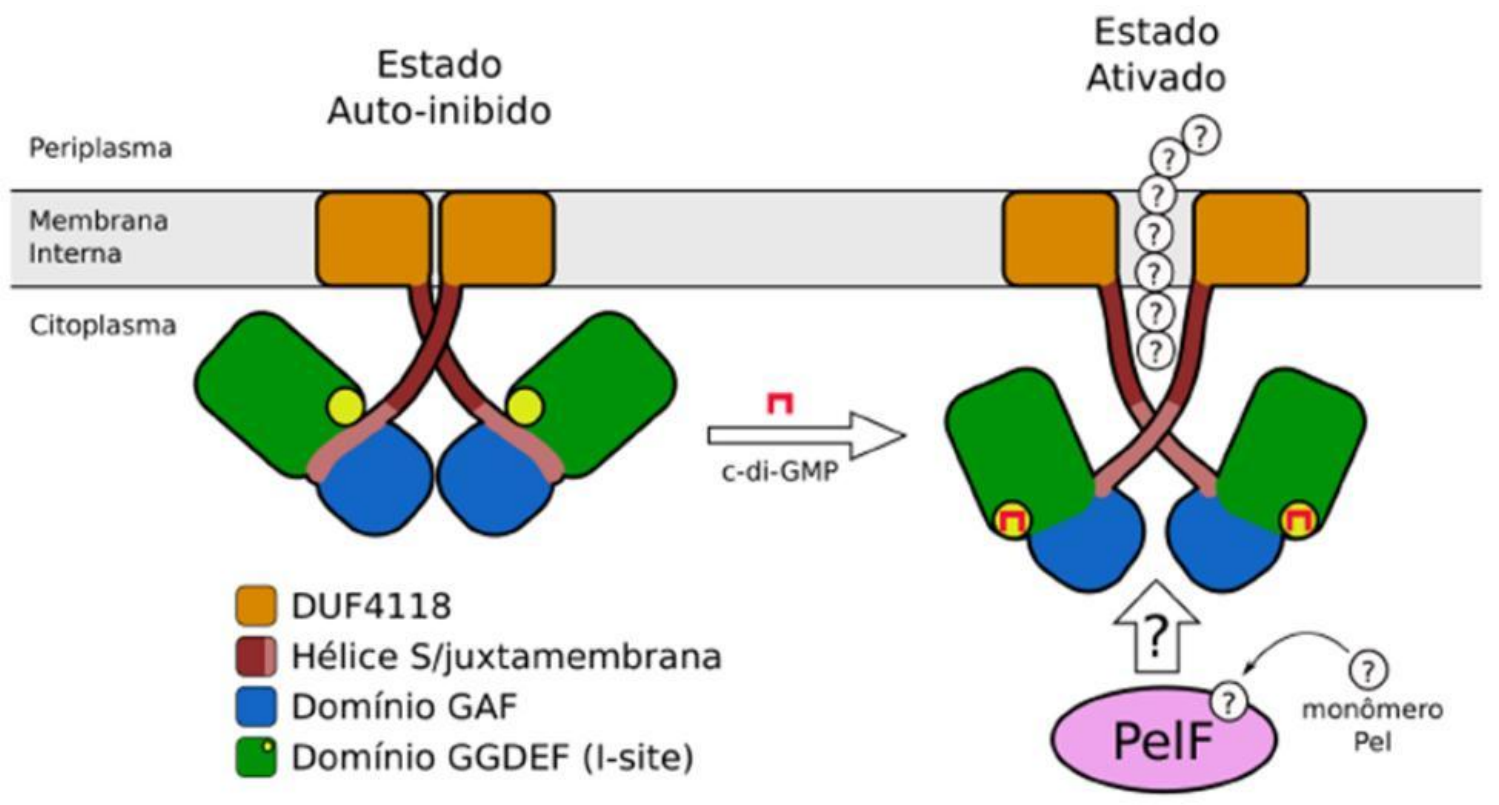

Figura 40 - Mecanismo proposto para ativação de PelD por c-di-GMP. A figura mostra que a partir do momento que a célula sofre estímulos externos, a concentração intracelular de c-di-GMP aumenta o que possibilita a interação com a porção citoplasmática da proteína PelD. Essa interação promove uma alteração conformacional em PelD, o que possibilita sua provável interação com a proteína PelF, uma glicosiltransferase que sintetiza o polímero pel. Sua exportação é facilitada pela interação desta com PelD fazendo com que o polímero Pel seja exportado para a região periplasmática de $P$. aeruginosa (PA14).

Os resultados obtidos nesse trabalho contribuem de forma significativa para o aumento do conhecimento científico global das vias de formação de biofilmes mediadas por c-di-GMP. Em especial, o trabalho fornece pela primeira vez evidências para um mecanismo molecular 
mediado por c-di-GMP de uma das etapas essenciais na formação de biofilmes: a exportação de polímeros da matrix extracelular.

\subsection{PERSPECTIVAS FUTURAS}

Embora PelD contenha um domínio GGDEF degenerado em vez de um domínio PilZ, pode desempenhar um papel funcionalmente equivalente na síntese, polimerização e exportação do polissacarídeo pel. (29-30) Uma caracterização profunda das proteínas do operon pel como também, análise do potencial de interações proteína-proteína irá fornecer uma visão mais detalhada do mecanismo da síntese desse tipo de polissacarídeo em Pseudomonas aeruginosa (PA14).

Experimentos envolvendo a amplificação da proteína inteira poderão esclarecer seu funcionamento in vivo, visto que, a ligação ou dissociação de uma proteína parceira e ligadora ao domínio GAF pode causar uma alteração conformacional no domínio N-terminal transmembranar de PelD, utilizando o mesmo como um regulador de sinal. O que poderia comprovar o mecanismo de ativação proposto neste trabalho. (29-30)

Além disso, pesquisas por meio de bioinformática revelaram que o domínio transmembranar do N-terminal de PelD é categorizado como um domínio de função desconhecida (DUF4118). Esse tipo de domínio existe em uma ampla variedade de proteínas de sinalização, que podem desempenhar um papel na transdução de sinal. Juntamente com outras duas proteínas da via como, PelE e PelG, que são previstas para conter hélices transmembranares, PelD poderia facilitar a exportação de substâncias contendo os carboidratos. (26)

Processos como descrito acima, exigem interações entre proteínas transmembranares e PelC, uma lipoproteína localizada na membrana externa, que mostra-se uma facilitadora do transporte de polissacarídeos. (29-30) Estudos bioquímicos, microbiológicos e estruturais serão necessários para caracterização da cascata de sinalização promovida pelas proteínas codificadas pelo operon pel em P. aeruginosa. Além disso, sinalizações mediadas por c-diGMP e seus receptores, são um alvo atraente para o desenvolvimento de antibióticos contra a formação de biofilme. 
Qeferénciass 


\section{REFERÊNCIAS}

1 TORTORA, G. J. F.; CASE, C. L. Microbiologia. 8 ed. Porto Alegre: Artemed, 2005. 894 p.

2 GEST, H. The discovery of microorganisms revisited. Features, v. 70, n. 6, p. 269-274, 2004.

3 ROMEO, T. (ed.) Bacterial biofilms: current topics in microbiology and immunology. Berlin: Springer Verlag, 2008. (Current Topics in Microbiology and Immunology, v. 322).

4 COSTERTON, J. W.; LEWANDOWSKI, Z.; CALDWELL, D. E.; KORBER, D. R.; LAPPIN-SCOTT, H.M. Microbial biofilms. In: Annual Review of Microbiology, v. 49, p. 711-745, 1995. DOI: 101146/annurev.mi.49.100195.003431.

5 COSTERTON, J. W; LEWANDOWSKI, Z. The biofilm lifestyle. Advances in Dental Research, v. 11, n. 1, p. 192-195, 1997.

6 O'TOOLE, G.; KAPLAN; H. B.; KOLTER, R. Biofilm formation as microbial development. Annual Review of Microbiology, v. 54, p. 49-79, 2000. DOI: 10.1146/annurev.micro.54.1.49

7 PLAKUNOV, Y. A. N. V. K. Biofilm - "City of Microbes" or an analogue of multicellular organisms? Microbiology, v. 76, n. 2, p. 149-163, 2007.

8 BRANDA, S. S.; VIK, A.; FRIEDMAN, L.; KOLTER, R. Biofilms: the matrix revisited. TRENDS in Microbiology, v. 13, n. 1, p. 20-26, 2005.

9 DONLAN, R. M. Biofilms: microbial life on surfaces. Emerging Infectious Diseases, v. 8, n. 9, p. 881-890, 2002.

10 ALEXANDER, M. Microbial communities and interactions: a prelude. In: HURST, C.J. (Ed.) Manual of environmental microbiology. Washington: AMS Press, 1997. p. 5-13.

11 VU, B.; CHEN, M.; CRAWFORD, R. J.; IVANOVA, E. P. Bacterial extracellular polysaccharides involved in biofilm formation. Molecules, v. 14, n. 7, p. 2535-2554, 2009. 
12 MELCHIOR, M. B.; VAARKAMP, H.; FINK-GREMMELS, J. Biofilms: a role in recurrent mastitis infections? Veterinary Journal, v. 171, n. 3, p. 398-407, 2006.

13 XAVIER, J. B.; PICIOREANU, C.; ALMEIDA, J. S.; VAN LOOSDRECHT, M. C. M. Monitorização e modelação da estrutura de biofilmes. Boletim de Biotecnologia: biomatemática-modelação da estrutura de biofilmes. Disponivel em: < www.biofilms.bt.tudelft.nl/pdf/2002_jxavier_biofilmes.pdf>. Acesso em: 20 jun. 2012.

14 KARATAN, E.; WATNICK, P. Signals, regulatory networks, and materials that build and break bacterial biofilms. Microbiology and Molecular Biology Reviews, v. 73, n. 2, p. 310347, 2009.

15ANJULI-MEHROTRA, M. D. Bacterial biofilms. Pediatric Asthma, Allergy \& Immunology, v. 20, n. 3, p. 191-195, 2007.

16 MADIGAN, M. T. et al. Microbiologia de Brock. 12 ed. Porto Alegre: Artmed, 2010. $1160 \mathrm{p}$.

17 VAN HOUDT, R.; MICHIELS, C. W. Biofilm formation and the food industry, a focus on the bacterial outer surface. Journal of Applied Microbiology, v. 109, n. 4, p. 1117-1131, 2010.

18 ELIAS, S.; BANIN, E. Multi-species biofilms: living with friendly neighbors. FEMS Microbiology Reviews, v. 36, n. 5, p. 990-1004, 2012.

19 JENAL, U.; MALONE, J. Mechanisms of cyclic-di-GMP signaling in bacteria. Annual Review of Genetics, v. 40, p. 385-407, 2006.

20 D'ARGENIO, D. A.; MILLER, S. I. Cyclic di-GMP as a bacterial second messenger. Microbiology, v. 150, p. 2497-2502, 2004. DOI 10.1099/mic.0.27099-0.

21 HENGGE, R. Principles of c-di-GMP signaling in bacteria. Nature Reviews Microbiology, v. 7, n. 4, p. 263-273, 2009.

22 SONDERMANN, H.; SHIKUMA, N. J.; YILDIZ, F. H. You've come a long way: c-diGMP signaling. Current Opinion in Microbiology, v.15, n.2, p.140-146, 2012.

23 CHRISTEN, B.; CHRISTEN, M.; PAUL, R.; SCHMID, F.; FOLCHER, M.; JENOE, P.; MEUWLY, M.; JENAL, U. Allosteric control of cyclic-di-GMP signaling. Journal of Biological Chemistry, v. 281, n. 42, p. 32015-32024, 2006. 
24 COTTER, P. A.; STIBITZ, S. C-di-GMP mediated regulation of virulence and biofilm formation. Current Opinion in Microbiology, v. 10, n. 1, p. 17-23, 2007.

25 SONDERMANN, H.; SHIKUMA, N. J.; YILDIZ, F. H. You've come a long way: c-diGMP signaling. Current Opinion in Microbiology, v. 15, n. 2, p. 140-146, 2012.

26 LEE, V. T.; MATEWISH, J. M.; KESSLER, J. L.; HYODO, M.; HAYAKAWA, Y.; LORY, S. A cyclic-di-GMP receptor required for bacterial exopolysaccharide production. Molecular Microbiology, v. 65, n. 6, p. 1474-1484, 2007.

27 FRANKLIN, M. J.; NIVENS, D. E.; WEADGE, J. T.; HOWELL, P. L. Biosynthesis of the Pseudomonas aeruginosa extracellular polysaccharides, alginate, Pel, and Psl. Frontiers in Microbiology: cellular and infection microbiology, v. 2, p. 167, 2011. DOI: 10.3389/fmicb.2011.00167.

28 FRIEDMAN, L.; KOLTER, R. Genes involved in matrix formation in Pseudomonas aeruginosa PA14 biofilms. Molecular Microbiology, v. 51, n. 3, p. 675-690, 2004.

29 WHITNEY, J. C.; COLVIN, K. M.; MARMONT, L. S.; ROBINSON, H.; PARSEK, M. R.; HOWELL, P. L. Structure of the cytoplasmic region of PelD, a degenerate diguanylate cyclase receptor that regulates exopolysaccharide production in Pseudomonas aeruginosa. Journal of Biological Chemistry, v. 287, n. 28, p. 23582-23593, 2012.

30 LI, Z.; CHEN, J. H.; HAO, Y.; NAIR, S. K. Structures of the PelD cyclic diguanylate effector involved in pellicle formation in Pseudomonas aeruginosa PAO1. Journal of Biological Chemistry, v. 287, n. 36, p. 30191-30204, 2012.

31 HALL-STOODLEY, L.; COSTERTON, J. W.; STOODLEY, P. Bacterial biofilms: from the natural environment to infectious diseases. Nature Reviews Microbiology, v. 2, n. 2, p. 95$108,2004$.

32 PARSEK, M. R.; SINGH, P. K. Bacterial biofilms: an emerging link to disease pathogenesis. Annual Review Microbiology, v.57, p.677-701, 2003. DOI: 10.1146/annurev.micro.57.030502.090720

33 FUX, C. A.; COSTERTON, J.W.; STEWART, P. S.; STOODLEY, P. Survival strategies of infectious biofilms. Trends in Microbiology, v. 13, n. 1, p. 34-40, 2005. 
34 HARE, N. J.; SOLIS, N.; HARMER, C.; MARZOOK, N. B.; ROSE, B.; HARBOUR, C.; CROSSETT, B.; MANOS, J.; CORDWELL, S. J. Proteomic profiling of Pseudomonas aeruginosa AES-1R, PAO1 and PA14 reveals potential virulence determinants associated with a transmissible cystic fibrosis-associated strain. BMC Microbiology, v. 12, n. 16, p. 1-14, 2012.

35 ANTUNES, L. C. M. Microbiologia: a liguagem das bactérias. Ciência Hoje, v. 33, n.193, p. 16-20, 2003.

36 CHRISTIAEN, S. E. A.; BRACKMAN, G.; NELIS, H. J.; COENYE, T. Isolation and identification of quorum quenching bacteria from environmental samples. Journal of Microbiological Methods, v. 87, n. 2, p. 213-219, 2011.

37 LEE, J. K. Bacterial quorum sensing and quorum quenching for the inhibition of biofilm formation. Korean Journal of Microbiology and Biotechnology, v. 40, n. 2, p. 83-91, 2012.

38 DUSANE, D. H.; ZINJARDE, S. S.; VENUGOPALAN, V. P.; MCLEAN, R. J. C.; WEBER, M. M.; RAHMAN, P. K. S. M. Quorum sensing: implications on rhamnolipid biosurfactant production. In: HARDING S.E. (Ed.) Biotechnology and Genetic Engineering Reviews, 2010. p. 159-184. (Biotechnology \& Genetic Engineering Reviews, v. 27).

39 STEINDLER, L.; BERTANI, I.; DE SORDI, L.; SCHWAGER, S.; EBERL, L.; VENTURI, V. LasI/R and RhlI/R quorum sensing in a strain of Pseudomonas aeruginosa beneficial to plants. Applied and Environmental Microbiology, v. 75, n. 15, p. 5131-5140, 2009.

40 UEDA, A.; WOOD, T. K. Connecting quorum sensing, c-di-GMP, pel polysaccharide, and biofilm formation in Pseudomonas aeruginosa through tyrosine phosphatase TpbA (PA3885). PLoS Pathogens, v. 5, n. 6, p. 1-15, 2009. DOI 10.1371/journal.ppat.1000483.

41 SINGH, P. K.; SCHAEFER, A. L.; PARSEK, M. R.; MONINGER, T. O.; WELSH, M. J.; GREENBERG, E. P. Quorum-sensing signals indicate that cystic fibrosis lungs are infected with bacterial biofilms. Nature, v. 407, n. 6805, p. 762-764, 2000.

42 MANN, E. E.; WOZNIAK, D. J. Pseudomonas biofilm matrix composition and niche biology. FEMS Microbiology Reviews, v. 36, n. 4, p. 893-916, 2012.

43 HENDRICKSON, E. L.; PLOTNIKOVA, J.; MAHAJAN-MIKLOS, S.; RAHME, L. G.; AUSUBEL, F. M. Differential roles of the Pseudomonas aeruginosa PA14 rpoN gene in pathogenicity in plants, nematodes, insects, and mice. Journal of Bacteriology, v. 183, n. 24, p. 7126-7134, 2001. 
44 VENTRE, I. et al. Multiple sensors control reciprocal expression of Pseudomonas aeruginosa regulatory RNA and virulence genes. Proceedings of the National Academy of Sciences of the United States of America, v. 103, n. 1, p. 171-176, 2006. . DOI: $10.1073 /$ pnas.0507407103.

45 MAYANSKY, A. N.; CHEBOTAR, I. V.; RUDNEVA, E. I.; CHISTYAKOVA, V. P. Pseudomonas aeruginosa: characteristics of the biofilm process. Molecular Genetics, Microbiology and Virology, v. 27, n. 1, p. 1-6, 2012. DOI: 10.3103/S0891416812010053.

46 GHAFOOR, A.; HAY, I. D.; REHM, B. H. A. Role of exopolysaccharides in Pseudomonas aeruginosa biofilm formation and architecture. Applied and Environmental Microbiology, v. 77, n. 15, p. 5238-5246, 2011.

47 HENTZER, M.; TEITZEL, G. M.; BALZER, G. J.; HEYDORN, A.; MOLIN, S.; GIVSKOV, M.; PARSEK, M. R. Alginate overproduction affects Pseudomonas aeruginosa biofilm structure and function. Journal of Bacteriology, v. 183, n. 18, p. 5395-5401, 2001.

48 ZEGANS, M. E.; WOZNIAK, D.; GRIFFIN, E.; TOUTAIN-KIDD, C. M.; HAMMOND, J. H.; GARFOOT, A.; LAM, J. S. Pseudomonas aeruginosa exopolysaccharide psl promotes resistance to the biofilm inhibitor polysorbate 80. Antimicrobial Agents and Chemotherapy, v. 56, n. 8, p. 4112-4122, 2012.

49 STOVER, C. K. E. A. Complete genome sequence of Pseudomonas aeruginosa PAO1, an opportunistic pathogen. Nature, v. 406, n. 6799, p. 959-964, 2000.

50 JACKSON, K. D.; STARKEY, M.; KREMER, S.; PARSEK, M. R.; WOZNIAK, D. J. Identification of psl, a locus encoding a potential exopolysaccharide that is essential for Pseudomonas aeruginosa PAO1 biofilm formation. Journal of Bacteriology, v. 186, n. 14, p. 4466-4475, 2004.

51 KANG, Y. H.; PARK, C. S.; HAN, M. S. Pseudomonas aeruginosa UCBPP-PA14 a useful bacterium capable of lysing Microcystis aeruginosa cells and degrading microcystins. Journal of Applied Phycology, v. 24, n. 6, p. 1-9, 2012.

52 ROMLING, U.; GOMELSKY, M.; GALPERIN, M.Y. C-di-GMP: the dawning of a novel bacterial signalling system. Molecular Microbiology, v.57, n.3, p. 629-639, 2005.

53 SIMM, R.; MORR, M.; KADER, A.; NIMTZ, M.; ROMLING, U. GGDEF and EAL domains inversely regulate cyclic di-GMP levels and transition from sessility to motility. Molecular Microbiology, v.53, n. 4, p. 1123-1134, 2004. 
54 KALIA, DIMPY; MEREY, GÖKÇE; NAKAYAMA, SHIZUKA; ZHENG, YUE; ZHOU, JIE; LUO, YILING; GUO, MIN; . ROEMBKEA, BENJAMIN T.; SINTIM, HERMAN O. Nucleotide, c-di-GMP, c-di-AMP, cGMP, cAMP, (p)ppGpp signaling in bacteria and implications in pathogenesis. Chemical Society Reviews, v. 42, p. 305-341, 2013. DOI:10.1039/C2CS35206K

55 STELITANO,V.; BRANDT, A.; FERNICOLA,S.; FRANCESCHINI, S.; GIARDINA, G.; PICA, A.; RINALDO, S.; SICA, F.; CUTRUZZOLA, F. Probing the activity of diguanylate cyclases and c-di-GMP phosphodiesterases in real-time by CD spectroscopy. Nucleic Acids Research, p. 1-9, 2013. DOI:10.1093/nar/gkt028.

56 BENACH, J.; SWAMINATHAN, S. S.; TAMAYO, R.; HANDELMAN, S. K.; FOLTASTOGNIEW, E.; RAMOS, J. E.; FOROUHAR, F.; NEELY, H.; SEETHARAMAN, J.; CAMILLI, A.; HUNT, J. F. The structural basis of cyclic diguanylate signal transduction by PilZ domains. EMBO Journal, v. 26, n. 24, p. 5153-5166, 2007.

57 SUDARSAN, N.; DEE, E. R.; WEINBERG, A.; MOY, R. H.; KIN, J. N.; LINK, K. H.; BREAKER, R. R. Riboswitches in eubacteria sense the second messenger cyclic-di-GMP, Science, v.321, n. 5887, p. 411-413, 2008. DOI: 10.1126/science.1159519.

58 WILKINS, M. R.; GASTEIGER, E.; BAIROCH, A.; SANCHEZ, J. C.; WILLIAMS, K. L.; APPEL, R. D.; HOCHSTRASSER, D. F. Protein identification and analysis tools in the ExPASy server. Methods in Molecular Biology, v. 112, p. 531-552, 1999. DOI: 10.1385/159259-584-7:531.

59 TUSNADY, G. E.; SIMON, I. The HMMTOP transmembrane topology prediction server. Bioinformatics Applications Note, v. 17, n. 9, p. 849-850, 2001.

60 MCGUFFIN, L. J.; BRYSON, K.; JONES, D. T. The PSIPRED protein structure prediction server. Bioinformatics, v. 16, n. 4, p. 404-405, 2000.

61 KELLEY, L. A.; STERNBERG, M. J. Protein structure prediction on the Web: a case study using the Phyre server. Nature Protocols, v. 4, n. 3, p. 363-371, 2009.

62 FARISELLI, P.; BARTOLI, L.; CASADIO, R. Improving coiled-coil prediction with evolutionary information. Lecture Notes in Computer Science (including subseries Lecture Notes in Artificial Intelligence and Lecture Notes in Bioinformatics), v. 6160, p. 20-32, 2010. DOI 10.1007/978-3-642-14571-1_2.

63 SWINDELL, S. R.; PLASTERER, T. N. SEQMAN conting assembly. Methods in Molecular Biology, v. 70,p. 75-89, 1997. DOI 10.1385/0-89603-358-9:75 
64 BRESOLIN, I. T. L.; MIRANDA, E. A.; BUENO, S. M. A. Cromatografia de afinidade por íons metálicos imobilizados (IMAC) de biomoléculas: aspectos fundamentais e aplicações tecnológicas. Química Nova, v. 32, n. 5, p. 1288-1296, 2009.

65 NELSON, D. L.; COX, M. M. Lehninger: principles of biochemistry. 5 ed. Porto Alegre: Artmed, 2008. 1274 p.

66 LIFESENSORS INC. Sumo gene fusion technology: new methods for enhancing protein expression and purification in prokaryotes. Philadelphia, 2003. 6 p. Disponivel em: $<$ http://wolfson.huji.ac.il/purification/PDF/Tag_Protein_Purification/SUMO/LifeSensors_SU MO_Prokar.pdf>. Acesso em: 18 set. 2012.

67 SILVA, I. R. Estudos biofísicos da selenofosfato sintetase de Escherichia coli e investigação de seu papel na via de biossíntese de Selenocisteínas. 2012. 140 p. Dissertação (Mestrado em Ciências) - Instituto de Física de São Carlos, Universidade de São Paulo, São Carlos, 2012.

68 ZAIA, D. A. M.; ZAIA, C. T. B. V.; LICHTING, J. Determinação de proteínas totais via espectrofotometria: vantagens e desvantagens dos métodos existentes. . Química Nova, v. 21, n. 6, p. 787-793, 1998.

69 ZÄHRINGER, F.; MASSA, C.; SCHIRMER, T. Efficient enzymatic production of the bacterial second messenger c-di-GMP by the diguanylate cyclase YdeH from E. coli. Applied Biochemistry and Biotechnology, v. 163, n. 1, p. 71-79, 2011.

70 LEBOWITZ, J.; LEWIS, M. S.; SCHUCK, P. Modern analytical ultracentrifugation in protein science: a tutorial review. Protein Science, v. 11, n. 9, p. 2067-2079, 2002.

71 BROWN, P. H.; BALBO, A.; SCHUCK, P. Using prior knowlede in the determination of macromolecular size-disrtributions by analytical ultracentrifugation. Biomacromolecules, v. 8, n. 6, p. 2011-2024, 2007.

72 SCHUCK, P. Size-distribution analysis of macromolecules by sedimentation velocity ultracentrifugation and Lamm equation modeling. Biophysical Journal, v. 78, n. 3, p. 1606$1619,2000$.

73 BROWN, P. H.; SCHUCK, P. Macromolecular size-and-shape distributions by sedimentation velocity analytical ultracentrifugation. Biophysical Journal, v. 90, n. 12, p. 4651-4661, 2006. 
74 JELESAROV, I.; BOSSHARD, H. Isothermal titration calorimetry and differential scanning calorimetry as complementary tools to investigate the energetics of biomolecular recognition. Journal of Molecular Recognition, v. 12, p. 3-18, 1999. DOI: 10.1007/978-160761-244-5_7.

75 LADBURY, J. E. Isothermal titration calorimetry: application to structure-based drug design. Thermochimica Acta, v. 380, n. 2, p. 209-215, 2001.

76 TURNBULL, W. B.; DARANAS, A. H. On the value of c: can low affinity systems be studied by isothermal titration calorimetry? Journal of the American Chemical Society, v. 125, n. 48, p. 14859-14866, 2003.

77 KELLY, S. M.; PRICE, N. C. The application of circular dichroism to studies of protein folding and unfolding. Biochimica et Biophysica Acta - protein structure and molecular enzymology, v. 1338, n. 2, p. 161-185, 1997.

78 RANJBAR, B.; GILL; P. Circular dichroism techniques: biomolecular and nanostructural analyses- a review. Chemical Biology \& Drug Design v. 74, p. 101-120, 2009. DOI 10.1111/j.1747-0285.2009.00847.x.

79 SREERAMA, N.; VENYAMINOV, S. Y.; WOODY, R. W. Estimation of the number of $\alpha$-helical and $\beta$-strand segments in proteins using circular dichroism spectroscopy. Protein Science, v. 8, n. 2, p. 370-380, 1999.

80 SREERAMA, N. W. Estimation of protein secondary structure from circular dichroism spectra: comparison of CONTIN, SELCON, and CDSSTR methods with an expanded reference set. Analytical Biochemistry, v. 287, p. 252-260, 2000.

81 McPHERSON, A. Introduction to macromolecular crystallography. 2 ed. Hoboken, N.J.: Wiley-Blackwell, 2009. 267 p.

82 RUPP, B. Biomolecular crystallography: principles, practice and application to structural biology. New York: Garland Science, 2010. 850 p.

83 McPHERSON, A. Protein crystallization in the structural genomics era. Journal of Structural and Functional Genomics, v. 5, n. 1-2, p. 3-12, 2004.

84 KABSCH, W. XDS. Acta Crystallographica D: biological crystallography, v. 66, n. 2, p. 125-132, 2010. 
$85 \mathrm{KABSCH}, \mathrm{W}$. Integration, scaling, space-group assignment and post-refinement. Acta Crystallographica, v. 66, n. 2, p. 133-144, 2010.

86 RICE, L. M.; EARNEST, T. N.; BRUNGER, A. T. Single-wavelength anomalous diffraction phasing revisited. Acta Crystallographica D: biological crystallography, v. 56, n. 11, p. 1413-1420, 2000.

87 SCHNEIDER, T. R.; SHELDRICK, G. M. Substructure solution with SHELXD. Acta Crystallographica D: biological crystallography, v. 58, n. 10, p. 1772-1779, 2002.

88 ADAMS, P. D.; AFONINE, P.V.; BUNKÓCZI, G.; CHEN, V. B.; DAVIS, I. W.; ECHOLS, N.; HEADD, J. J.; HUNG, L.W.; KAPRAL, G. J.; GROSSE-KUNSTLEVE, R. W.; MCCOY, A. J.; MORIARTY, N. W.; OEFFNER, R.; READ, R. J.; RICHARDSON, D. C.; RICHARDSON, J. S.; TERWILLIGER, T. C.; ZWART, P. H. PHENIX: a comprehensive Python-based system for macromolecular structure solution. Acta Crystallography D: biological crystallography, v. 66, n. 2, p. 213-221, 2010.

89 EMSLEY, P.; COWTAN, K. Coot: model-building tools for molecular graphics. Acta Crystallographica D: biological crystallography, v. 60, n. 121, p. 2126-2132, 2004.

90 CHEN, V. B. A.; HEADD, J. J.; KEED, D. A.; IMMORMINO, R. M.; KAPRAL, G. J.; MURRAY, L. W.; RICHARDSON, J. S.; RICHARDSON, D. C. MolProbity: all-atom structure validation for macromolecular crystallography. Acta Crystallographica D: biological crystallography, v. 66, pt 1, p. 12-21, 2010.

91 LASKOWSKI, R. A. et al. PROCHECK: a program to check the stereochemical quality of protein structure. Journal of Applied Crystallography, v. 26, n. 2, p. 283-291, 1993.

92 PUNTA, M. et al. The Pfam protein families database. Nucleic Acids Research, v. 40, n. D1, p. D290-D301, 2012.

93 PASI, M.; TIBERTI, M.; ARRIGONI, A.; PAPALEO, E. XPyder: a PyMOL plugin to analyze coupled residues and their networks in protein structures. Journal of Chemical Information and Modeling, v. 52, n. 7, p. 1865-1874, 2012.

94 HOLM, L. R., P. Dali server: conservation mapping in 3D. Nucleic Acids Research, v. 38, suppl. 2, p. W545-W549, 2010. DOI: 10.1093/nar/gkq366. 
95 CHO, H. Y.; CHO, H. J.; KIM, Y. M.; OH, J. I.; KANG, B. S. Structural insight into the Heme-based redox sensing by DosS from Mycobacterium tuberculosis. The Journal of Biological Chemistry, v. 284, n.19, p. 13057-13067, 2009.

96 CHAN, C.; PAUL, R.; SAMORAY, D.; AMIOT, N. C.; GIESE, B.; JENAL, U.; SCHIRMER, T. Structural basis of activity and allosteric control of diguanylate cyclase. Proceedings of the National Academy of Sciences of the United States of America, v. 101, n. 49, p. 17084-17089, 2004.

97 SCHMID, F. F. M. All-atom simulations of structures and energetics of c-di-GMP-bound and free PleD. Journal of Molecular Biology, v. 374, n. 5, p. 1270-1285, 2007.

98 MALONE, J. G.; CHRISTEN, M.; JENAL, U.; SPIERS, A. J.; RAINEY, P. B. The structure-function relationship of WspR, a Pseudomonas fluorescens response regulator with a GGDEF output domain. Microbiology, v. 153, n. 4, p. 980-994, 2007.

99 NAVARRO, M. V. A. S.; DE, N.; BAE, N.; WANG, Q.; SONDERMANN, H. Structural analysis of the GGDEF-EAL domain-containing c-di-GMP receptor FimX. Structure, v. 17, n. 8, p. 1104-1116, 2009.

100 NAVARRO, M. V.; NEWELl, P. D.; KRASTEVA, P. V.; CHATTERJEE, D.; MADDEN, D. R.; O'TOOLE, G. A.; SONDERMANN, H. Structural basis for c-di-GMPmediated inside-out signaling controlling periplasmic proteolysis. PLoS Biology, v. 9, n. 2, p. e1000588, 2011.

101 NEWELL, P. D.; MONDS, R. D.; O'TOOLE, G. A. LapD is a bis-(3',5')-cyclic dimeric GMP-binding protein that regulates surface attachment by Pseudomonas fluorescens Pf0-1. Proceedings of the National Academy of Sciences of the United States of America, v. 106, n. 9, p. 3461-3466, 2009. 